
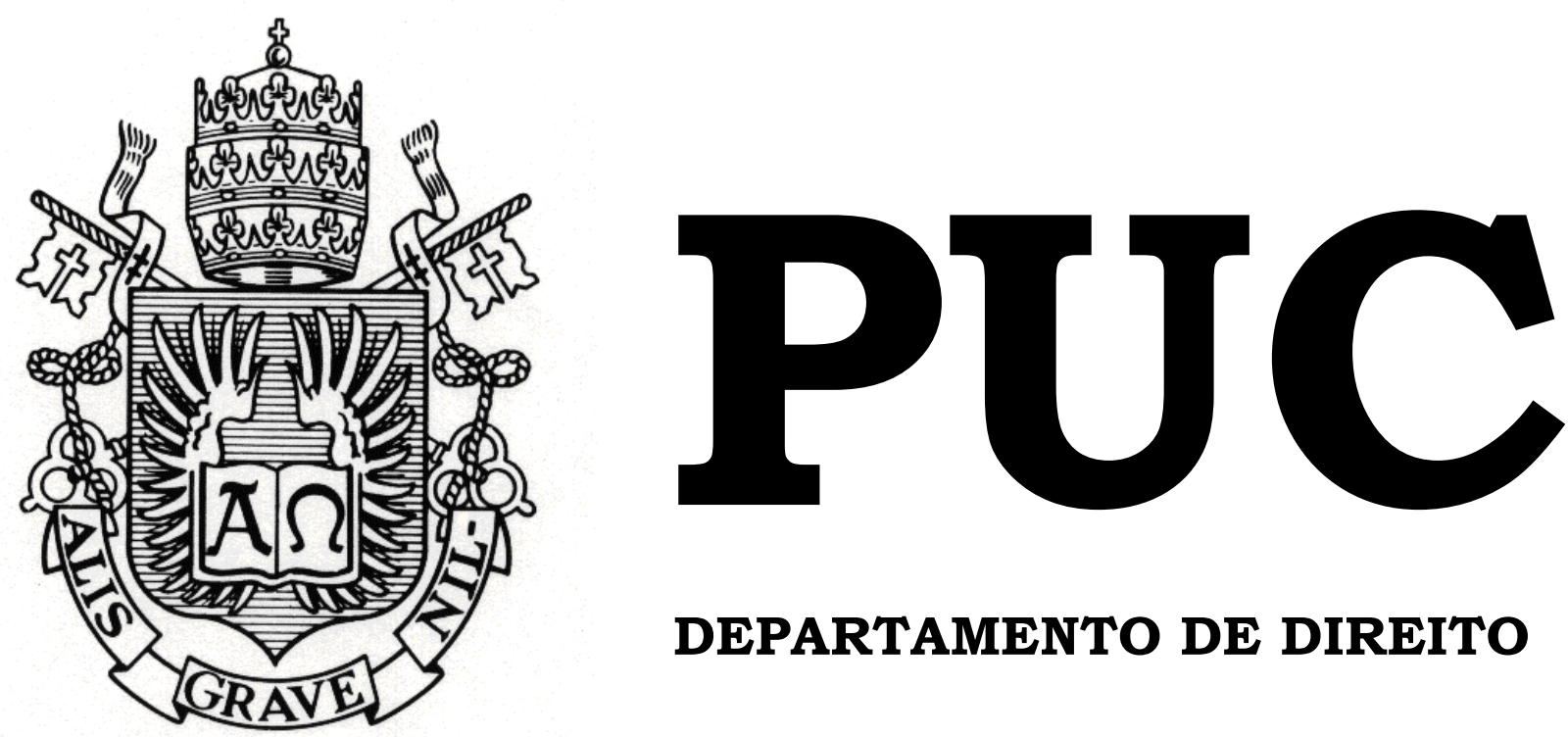

DEPARTAMENTO DE DIREITO

O INSTITUTO DA COLABORAÇÃO PREMIADA

Por

LUCAS MEIRELES DA SILVA DELORENZI

ORIENTADOR: Salvador Bemerguy

2019.2

PONTIFÍCIA UNIVERSIDADE CATÓLICA DO RIO DE JANEIRO

RUA MARQUÊS DE SÃO VICENTE, 225 - CEP 22451-900

RIO DE JANEIRO - BRASIL 


\title{
O INSTITUTO DA COLABORAÇÃO PREMIADA
}

\author{
por \\ LUCAS MEIRELES DA SILVA DELORENZI
}

\begin{abstract}
Monografia apresentada ao
Departamento de Direito da

Pontifícia Universidade Católica do

Rio de Janeiro (PUC-Rio) como

requisito parcial para a obtenção do

Título de Bacharel em Direito.
\end{abstract}

Orientador: Salvador Bemerguy

2019.2 


\section{AGRADECIMENTOS}

Em primeiro lugar, gostaria de agradecer à minha família, tão paciente e motivadora nesse momento de toda complexidade e apreensão que uma elaboração do trabalho de conclusão de curso e término de uma graduação podem trazer.

À Júlia, que tranquilamente sempre me reconfortou e auxiliou nos momentos difíceis de exaustão e receio.

Ao meu professor-orientador Salvador Bemerguy, profissional o qual admiro, que nessa jornada sempre esteve à disposição, ajudando com toda sua experiência e conhecimento.

E a todos os componentes do Departamento de Direito e do Núcleo de Prática Jurídica da PUC-Rio, sempre solícitos e amigáveis. 


\section{RESUMO}

DELORENZI, Lucas Meireles da Silva. O Instituto da Colaboração Premiada. Rio de Janeiro, 2019. 109 p. Monografia de final de curso. Departamento de Direito da Pontifícia Universidade Católica do Rio de Janeiro - PUC-Rio.

O objetivo do presente trabalho é, num primeiro momento, apresentar a colaboração premiada, explicando esse mecanismo tão particular inserido no âmbito do processo penal, e quais foram as inspirações que levaram à sua elaboração, inserção e evolução no ordenamento jurídico brasileiro. Posteriormente, pretende-se realizar um estudo aprofundado sobre os principais aspectos procedimentais do instituto, que foram trazidos pela Lei 12.850 de 2013, e analisar os pontos mais debatidos pela doutrina e jurisprudência, baseado em diversas argumentações defendidas por autores conceituados e decisões proferidas nos tribunais pátrios, inclusive no contexto da célebre Operação Lava Jato. Ao final, serão elencadas algumas críticas feitas por juristas contrários à expansão da justiça negocial e à aplicação da colaboração como ferramenta na persecução penal. Por meio da leitura do presente, espera-se, por derradeiro, demonstrar a verdadeira função e a serventia da colaboração premiada como alternativa favorável à investigação criminal. Contudo, deve-se atentar aos seus limites e condições, sempre resguardando-se sob o prisma da legalidade para que não sobrevenham quaisquer violações aos preceitos fundamentais.

Palavras-Chave: Colaboração premiada. Justiça negocial. Processo penal. Procedimento. Legislação. 


\section{ABSTRACT}

The purpose of this paper is, at first, to introduce the awarded collaboration sistem, clarifying about this particular method within the criminal process, and which were the inspirations that led to its elaboration, insertion and evolution in the brazilian legal system. After that, it is intended to make an in-depth study about the mais procedural aspects of the institute, brought by the Law No. 12.850/13, and analyze the most discussed point by the doctrine and jurisprudence, based on several arguments defended by well-known and reputable authors and judgements given throughout our national Courts, including those pronounced in the context of the famous "Lava Jato" Operation. Finally, some criticisms made by jurists that are against the expansion of negotiated justice and the use of collaboration as a tool in criminal prosecutoin will be listed. By reading this paper, in the end it is expected to evidence the truly role and value of the awarded collaboration as a propitious alternative to criminal investigation. Nevertheless, it must be considered its limits and conditions, always being supported by legality, so that none fundamental rights would be violated.

Key-words: Awarded collaboration. Negotiated justice. Criminal process. Procedure. Legislation. 


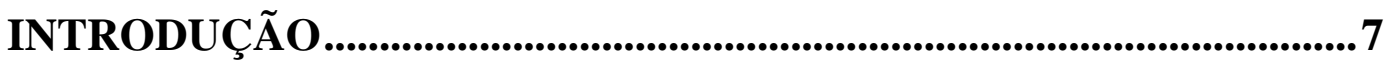

CAPÍTULO 1 - PRIMEIRAS NOTAS SOBRE A COLABORAÇÃO

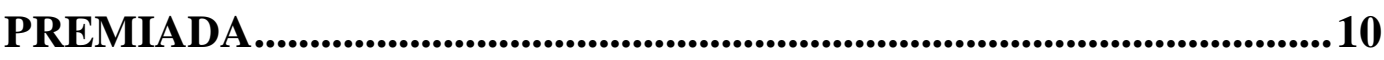

1.1. Natureza Jurídica da Colaboração Premiada .................................11

1.2. Diferença entre Colaboração Premiada e Delação Premiada ....14

1.3. Histórico da Colaboração Premiada .................................................18

CAPÍTULO 2 - A EVOLUÇÃO DA COLABORAÇÃO PREMIADA

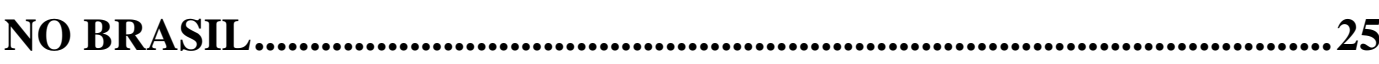

2.1. Lei 8.072/1990 - Lei de Crimes Hediondos .......................................25

2.2. Lei 8.137/1990 - Lei dos Crimes Contra a Ordem Tributária, Econômica e Relações de Consumo ............................................................27

2.3. Lei 9.034/1995 - Antiga Lei do Crime Organizado (Revogada).29

2.4. Lei 9.613/1998 - Lei de Lavagem de Bens e Capitais......................31

2.5. Lei 9.807/1999 - Lei de Proteção a Vítimas e Testemunhas.........33

2.6. Lei 10.409/2002 e Lei 11.343/2006 - Leis de Drogas........................35

CAPÍTULO 3 - O SISTEMA DA LEI 12.850/2013 - LEI DE CRIME

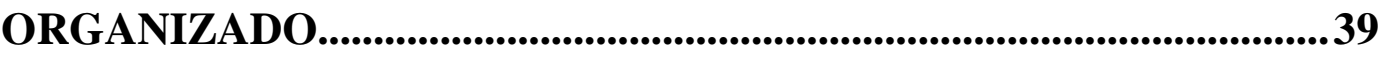

3.1. Espécies de Colaboração Premiada ....................................................41

3.1.1. A Delação Premiada ..................................................................4 42

3.1.2. A Colaboração Preventiva ....................................................... 43

3.1.3. A Colaboração para Localização e Recuperação de Ativos.. 44

3.1.4. A Colaboração para Libertação ................................................ 46

3.2. Pressupostos e Requisitos para Celebração e Cumprimento do Acordo de Colaboração Premiada .................................................................47

3.2.1. Pressupostos de Admissibilidade .............................................. 47

3.2.2. Requisitos de Validade .......................................................... 52

3.3. Legitimidade para propor o Acordo de Colaboração Premiada ....................................................................................................................58 
3.3.1. A Decisão do Supremo Tribunal Federal na ADI 5508 Possibilidade de Acordos de Colaboração Premiada Firmados por Delegados de Polícia................................................................... 62

3.4 Prêmios Legais: a Discussão Sobre a Taxatividade do Modelo Previsto na Lei 12.850/13 e o seu Esvaziamento na Prática................67 3.4.1. A Mitigação do Princípio da Obrigatoriedade da Ação Penal

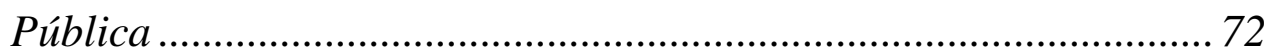

3.5. Formalidades do Instrumento de Colaboração Premiada...........80 CAPÍTULO 4 - CRÍTICAS AO INSTITUTO............................................8 84 CONCLUSÃ O .........................................................................................95 REFERÊNCIAS BIBLIOGRÁFICAS .....................................................98 


\section{INTRODUÇÃO}

Em virtude da perdurável crise há muito observada no sistema persecutório brasileiro, combinado com a crescente criminalidade desempenhada de forma articulada e inteligente, o poderio estatal (detentor do monopólio da pretensão punitiva), amparado por anseios populares e influências externas, se viu na obrigatoriedade de promover modificações de forma a gerar maior auxílio nas suas atividades investigativa e punitiva. De fato, nas últimas décadas, pudemos observar algumas reformas legislativas e na prática da justiça criminal.

Uma das alternativas vislumbradas foi a tentativa de ampliação dos consensos inseridos no processo penal, nos quais ambas as partes acusação e defesa - possuem maior autonomia para buscarem soluções interessantes para ambos os lados, na medida do possível. Quando falamos em justiça penal negocial, causa certa estranheza, e até certo temor por parte de alguns, que o Estado possa ofertar prêmios, abrandando a sanção, ou até mesmo perdoando réu confesso em processo criminal, visando obter informações acerca de outros sujeitos ou elementos pertencentes àquela prática delituosa. Estaríamos diante do exício do Estado Democrático de Direito?

Apesar dessa liberdade conferida às partes nessa nova sistemática, ela não possui caráter absoluto, devendo respeitar-se alguns postulados inerentes ao devido processo legal, e por óbvio, os ditames constitucionais. Temos então uma primeira e grande divergencia com a metodologia da plea bargain norte-americana, instituto que serviu de inspiração nesse novo caminho, adequando-se, contudo, às normas constitucionais.

Nesta toada, além das possibilidades já reguladas no final do século passado por intermédio da lei 9.099 de 1995 (Lei dos Juizados Especiais), nos últimos anos a colaboração premiada vêm ganhando uma notoriedade cada vez maior no campo jurídico-penal, tornando-se instrument de grande 
serventia na area processual. É bem verdade que a ideia de tal instituto, como constatar-se-á no decorrer do presente, não é novidade em nosso ordenamento; mas a Lei 12.850 de 2013 (Lei do Crime Organizado), genuinamente, a detalhou e inovou ao trazer os aspectos procedimentais relativos à sua aplicação.

Ainda que a Lei 12.850/13, principal pilar deste trabalho, tenha nos brindado com significativos avanços no que concerne à colaboração premiada, algumas questões passiveis de críticas ainda estão indefinidas na doutrina e jurisprudência. Da mesma forma, quando do seu emprego, certas diretrizes do Direito não estão sendo bem observadas nos casos em que o diploma restou silente

Estabelecidas tais premissas, o objetivo principal deste trabalho é realizar um estudo dogmático, fazendo um apanhado sobre o regramento incorporado pela Lei do Crime Organizado e como os operadores do Direito e tribunais vêm entendendo o disposto por esta norma. Nesta esteira, pretende-se explicar os descontentamentos oriundos de uma nova legislação que versa sobre um tópico tão importante e sensível para todos os envolvidos no contexto; mas, simultaneamente, afirmar o valor e a essencialidade que o instituto detém para a eficiência da persecução penal, nos moldes em que esta se apresenta nos dias atuais.

A metodologia utilizada na elaboração do trabalho foi estruturada em torno de alguns pontos centrais, como uma análise preliminar do instituto; menção à algumas espécies de negócio no processo penal existentes no plano internacional, quais sejam: a plea bargain nos Estados Unidos e o pattenggiamento na Itália, elencando suas semelhanças e distinções com a colaboração premiada; um breve exame das legislações nacionais anteriores que previam algum instituto que se assemelhasse à colaboração premiada que possuímos atualmente; uma profunda análise à Lei 12.850/13, abordando seus aspectos materiais e procedimentais, especificando as 
espécies de colaboração, atentando-se ainda aos seus pressupostos e requsitos legais e às formalidades necessárias.

Serão trazidos ainda, alguns debates amplamente em voga, em sede doutrinária e jurisprudencial, como a legitimidade para propor o acordo de colaboração e a controversa decisão do Supremo Tribunal Federal que a estendeu aos delegados de polícia; a dúvida sobre a taxatividade das hipóteses de prêmios legais e a sua não observância nos acordos firmados no âmbito da Lava Jato; e a colaboração como sendo uma tangível exceção ao princípio da obrigatoriedade da ação pública, vigente em nosso ordenamento. Por fim, sera posto em discussão algumas críticas inevitáveis que se fizeram ao instituto, devido às suas tensões com o devido processo, contrabalanceando-as com argumentos em sentido oposto.

Para o desenvolvimento da pesquisa e embasamento argumentative, serão utilizados a legislação nacional, orientações e manuais desenvolvidos na esfera interna do Ministério Público, bem como a vasta doutrina e jurisprudência, que, dada a relevância do instituto, debruçaram-se sobre o tema e produziram obras competentes e notáveis para a comunidade jurídica; ainda que nem sempre uníssonas. 


\section{CAPÍTULO 1 - PRIMEIRAS NOTAS SOBRE A COLABORAÇÃO PREMIADA}

A colaboração premiada, como se apresenta atualmente, é, em linhas gerais, um mecanismo de investigação na persecução penal, que tem como objetivo a produção de provas.

De maneira simplória, é um ato praticado pelo réu, que, ao confessar sua participação em determinada prática delituosa e integrante de uma organização criminosa, quando preenchidos os requisitos legais, utiliza-se de sua posição e presta ao Estado informações úteis para investigação dessa, visando benefício pessoal no âmbito do processo penal.

Inúmeras são as conceituações doutrinárias sobre o instituto. Para Mário Sérgio Sobrinho, a colaboração premiada:

É o meio de prova pelo qual o investigado ou acusado, ao prestar suas declarações, coopera com a atividade investigativa, confessando crimes e indicando a atuação de terceiros envolvidos com a prática delitiva, de sorte a alterar o resultado das investigações em troca de benefícios processuais ${ }^{1}$.

Sobre o mesmo tema, Sérgio Fernando Moro leciona:

A delação premiada consiste, em síntese, na utilização de um criminoso como testemunha contra seus cúmplices. Sua colaboração pode ser utilizada para que ele deponha em juízo como testemunha contra seus pares ou apenas para que sirva de fonte de informação para a colheita de outras provas² ${ }^{2}$

Já para Renato Brasileiro de Lima, trata-se de:

Espécie do Direito Premial, a colaboração premiada pode ser conceituada como uma técnica especial de investigação por meio da qual o coautor e/ou partícipe da infração penal, além de confessar seu envolvimento no fato delituoso, fornece aos órgãos responsáveis pela persecução penal informações objetivamente eficazes

\footnotetext{
1 SÉRGIO SOBRINHO, Mário. O crime organizado no Brasil. In: FERNANDES, Antonio Scarance; ALMEIDA, José Raul Gavião; MORAES, Maurício Zanoide de (coord.). Crime organizado: aspectos processuais. São Paulo: RT, 2009. p. 47.

${ }^{2}$ MORO, Sérgio Fernando. Crime de lavagem de dinheiro. São Paulo: Saraiva, 2010. p. 103.
} 
para a consecução de um dos objetivos previstos em lei, recebendo, em contrapartida, determinado prêmio legal ${ }^{3}$.

No Recurso em Habeas Corpus $n^{\circ}$ 69.988/RJ, julgado pelo STJ, o ministro relator do caso Reynaldo Soares da Fonseca assim definiu:

A colaboração premiada é uma técnica especial de investigação, meio de obtenção de prova advindo de um negócio jurídico processual personalíssimo, que gera obrigações e direitos entre as partes celebrantes (Ministério Público e colaborador), não possuindo o condão de, por si só, interferir na esfera jurídica de terceiros, ainda que citados quando das declarações prestadas, faltando, pois, interesse dos delatados no questionamento quanto à validade do acordo de colaboração premiada celebrado por outrem $(\ldots)^{4}$.

À luz da Lei $\mathrm{n}^{\circ} 12.850 / 13$, para fazer jus aos benefícios da colaboração premiada, o investigado deve, além de confessar sua participação, fornecer informações úteis e eficazes para a investigação da organização criminosa a qual pertence, sem as quais os órgãos responsáveis não teriam conhecimento; podendo indicar coautores, locais do crime, planejamentos delituosos, liberação de sequestrado, etc; se, por sua vez, fornecer informações já conhecidas pelas autoridades, estaremos diante de simples e já conhecida atenuante de confissão, prevista no Código Penal.

\subsection{Natureza Jurídica da Colaboração Premiada}

A definição da natureza jurídica da colaboração premiada não encontra revestimento uníssono e tampouco é pacífica na doutrina, e por isso muitas vezes é dada como sendo "mista". Marcos Paulo Dutra Santos, por exemplo, defende que o acordo de colaboração premiada possui uma natureza "processual material - forma e conteúdo processuais, mas com efeitos materiais"

\footnotetext{
${ }^{3}$ LIMA, Renato Brasileiro de. Manual de Processo Penal. $2^{\mathrm{a}}$ ed., rev. ampl. e atual. Salvador: JusPODIVM, 2014. p. 728-729.

${ }^{4}$ BRASIL. Superior Tribunal de Justiça. Recurso em Habeas Corpus $n^{\circ}$ 69.988/RJ. Recorrente: Artur Cruz Junior e outros. Recorrido: Ministério Público do Estado do Rio de Janeiro. Rel. Min. Reynaldo Soares da Fonseca. Brasília, 25 out. 2016.

${ }^{5}$ SANTOS, Marcos Paulo Dutra. Colaboração (delação) premiada. Salvador: Juspodivm, 2016. p.
} 
Conforme redação da lei supracitada, pode-se considerar a colaboração premiada como meio de obtenção de prova. O artigo $3^{\circ}$, I é cristalino nesse sentido:

Art. $3^{\circ}$ Em qualquer fase da persecução penal, serão permitidos, sem prejuízo de outros já previstos em lei, os seguintes meios de obtenção da prova:

I - colaboração premiada; $(\ldots)^{6}$.

Fundamental, neste momento, fazer uma diferenciação entre meio de obtenção de prova e meio de prova, para melhor compreensão. A colaboração premiada não pertence a este último, mas sim ao anterior, sendo ela uma técnica, uma ferramenta, um mecanismo que possibilita obter provas. Gustavo Badaró é assertivo nesse ponto:

\begin{abstract}
Enquanto os meios de prova são aptos a servir, diretamente, ao convencimento do juiz sobre a veracidade ou não de uma afirmação fática (p. ex., o depoimento de uma testemunha, ou o teor de uma escritura pública), os meios de obtenção de provas (p. ex.: uma busca e apreensão) são instrumentos para a colheita de elementos ou fontes de provas, estes sim, aptos a convencer o julgador (p. ex.: um extrato bancário [documento] encontrado em uma busca e apreensão domiciliar). Ou seja, enquanto o meio de prova se presta ao convencimento direto do julgador, os meios de obtenção de provas somente indiretamente, e, dependendo do resultado de sua realização, poderão servir à reconstrução da história dos fatos ${ }^{7}$.
\end{abstract}

Não se deve, portanto, atribuir à colaboração premiada status de prova em si, uma vez que deve ser tratada como um caminho para se chegar ao conteúdo probatório desejado. Tão somente pode o magistrado estabelecer seu convencimento em relação às provas propriamente ditas, e não somente ao teor dos acordos colaborativos, o que é expressamente vedado pela mesma Lei 12.850/13, que em seu artigo $4^{\circ}$ dispõe: “§ 16 . Nenhuma sentença condenatória será proferida com fundamento apenas nas declarações de agente colaborador”.

87.

${ }^{6}$ BRASIL. Lei $n^{\circ} 12.850$ de 02 de agosto de 2013. Dispõe sobre a prevenção, o tratamento, a fiscalização, o controle e a repressão à produção, ao uso e ao tráfico ilícitos de produtos, substâncias ou drogas ilícitas que causem dependência física ou psíquica, assim elencados pelo Ministério da Saúde, e dá outras providências. Brasília, DF, 02 ago. 2013.

${ }^{7}$ BADARÓ, Gustavo. Processo Penal. Rio de Janeiro: Campus, 2012. p. 270. 
O Supremo Tribunal Federal, por ocasião do julgamento do Habeas Corpus $\mathrm{n}^{\circ} 127.483 / \mathrm{PR}$, que teve como relator o Ministro Dias Toffoli, debruçou-se sobre a conceituação do instituto, destacando a significação atribuída pela lei, e, de acordo com entendimento do Ministro, definiu-o como um "negócio jurídico processual". Veja-se alguns trechos:

\begin{abstract}
A colaboração premiada é um negócio jurídico processual personalíssimo, uma vez que, além de ser qualificada expressamente pela lei como 'meio de obtenção de prova', seu objeto é a cooperação do imputado para a investigação e para o processo criminal, atividade de natureza processual, ainda que se agregue a esse negócio jurídico o efeito substancial (de direito material) concernente à sanção premial a ser atribuída a essa colaboração. Dito de outro modo, embora a colaboração premiada tenha repercussão no direito penal material (ao estabelecer as sanções premiais a que fará jus o imputado colaborador, se resultar exitosa sua cooperação), ela se destina precipuamente a produzir efeitos no âmbito do processo penal (...).
\end{abstract}

Como se observa, a colaboração premiada, como meio de obtenção de prova, destina-se à "aquisição de entes (coisas materiais, traços [no sentido de vestígios ou indícios] ou declarações) dotados de capacidade probatória", razão por que não constitui meio de prova propriamente dito. Outrossim, o acordo de colaboração não se confunde com os depoimentos prestados pelo agente colaborador. Enquanto o acordo de colaboração é meio de obtenção de prova, os depoimentos propriamente ditos do colaborador constituem meio de prova, que somente se mostrarão hábeis à formação do convencimento judicial se vierem a ser corroborados por outros meios idôneos de prova. (...)

Note-se que a Lei n. 12.850/13 expressamente se refere a um 'acordo de colaboração' e às 'negociações' para a sua formalização, a serem realizadas 'entre delegado de polícia', o investigado e o defensor, com a manifestação do Ministério Público, ou, conforme o caso, entre o Ministério Público e o investigado ou acusado e seu defensor' $\left(\operatorname{art} .4^{\circ}, \S 6^{\circ}\right.$ ), a confirmar que se trata de um negócio jurídico processual ${ }^{8}$.

Em que pese a divergência acerca da classificação da natureza jurídica da colaboração premiada, não restam dúvidas sobre sua essência penal, funcionando como um incentivo à cooperação com o Estado em troca de uma diminuição da sanção penal, ou até mesmo de um perdão judicial.

\footnotetext{
${ }^{8}$ BRASIL. Supremo Tribunal Federal. Habeas Corpus $n^{\circ}$ 127.483/PR. Paciente: Erton Medeiros Fonseca. Impetrante: José Luiz Oliveira Lima e outros. Rel. Min. Dias Toffoli. Brasília, 27 ago. 2015.
} 
Dessa forma, a partir do conteúdo doutrinário e jurisprudencial esposado, parece correta, portanto, a atribuição de natureza mista à colaboração premiada, identificada sua multidisciplinaridade em relação ao direito material e processual. Do mesmo modo que constitui um instrumento de investigação criminal com a finalidade de conquista de provas, também pode ser vista sob a ótica de constituir uma maneira de defesa, ou seja, o recebimento de benefícios ao contribuir com esta investigação.

Sintetizando essa posição, o Procurador da República Flávio Pereira da Costa Matias assim entende:

O acordo de colaboração premiada, destarte, possui natureza mista, a depender do conteúdo da cláusula que estiver em xeque. Essa constatação, entretanto, não rechaça o caráter negocial do acordo de colaboração premiada $(. . .)^{9}$.

\subsection{Diferença entre Colaboração Premiada e Delação Premiada}

Ainda nesta parte inicial do presente trabalho, mister pontuar a diferença existente entre os dois conceitos, que reiteradamente acabam por ser empregados de forma equivocada, ou ainda, acabam sendo utilizados como sinônimos. A princípio, podem parecer institutos iguais - o que de fato são para alguns autores - mas analisando-os a fundo, podemos perceber sua diferenciação.

Rogério Sanches Cunha e Ronaldo Batista Pinto atribuem igualdade a ambos: "O instituto da colaboração premiada, ainda que contando com nomenclatura diversa, sempre foi objeto de análise pela doutrina, tratado que é como "delação premiada (ou premial) (...)"10.

Do mesmo modo, Gustavo de Meringhi e Rejane Alves de Arruda também entendem serem sinônimos as duas práticas:

\footnotetext{
9 MATIAS, Flávio Pereira da Costa. Sistema de Justiça Criminal. Brasília: Escola Superior do Ministério Público da União. 2018. p. 117.

${ }^{10}$ CUNHA, Rogério Sanches; PINTO, Ronaldo Batista. Crime Organizado - comentários à nova lei sobre o Crime Organizado - lei 12.850/13. Salvador: Juspodivm. 2013. p. 34.
} 
Embora a nova lei tenha utilizado a expressão "colaboração premiada", a maior parte da doutrina emprega o termo "delação premiada, que podem ser considerados sinônimos para fins didáticos ${ }^{11}$.

Não há como desconsiderar a posição dos juristas acima. Ainda assim, não parece posição mais acertada a ser adotada. Como o próprio nome sugere, ao falarmos de colaboração premiada estamos tratando de uma concepção mais ampla que a delação premiada.

Todavia, antes de adentrar nesta separação que se pretende fazer, devemos observar um ponto comum entre os dois institutos: a assunção da culpa. Importante ressaltar que só há que se falar em delação ou colaboração se o investigado assumir a culpa da infração. Em não assumindo para si a responsabilidade junto com os quais imputa a prática criminosa ou às demais informações prestadas, ou seja, negando sua própria participação porém apontando supostos terceiros que teriam cometido tal ato, produtos do crime, localizações, etc., estamos diante de mero testemunho. Isso ocorre pela própria natureza do instituto. Ora, se o indivíduo jura não ter cometido o crime, não há motivos para estar numa colaboração premiada, para obter benefícios acerca de sanções resultantes de uma ação penal a qual não teria de responder, ou que ao final no mínimo seria declarado inocente.

Ao confessar a autoria da infração penal, assumindo assim a culpa, o indivíduo têm algumas alternativas sobre a maneira como poderá colaborar, se cumprir os requisitos legais e se assim desejar. Nos casos passíveis de colaboração, pode o colaborador trazer à investigação o nome de diversas pessoas que também tenham participado na ação delituosa, com o objetivo de beneficiar-se, de acordo com a lei, a partir dessa acusação. Estamos, nesse caso, diante da delação premiada (ou chamamento de corréu). Percebe-se, neste caso, que está presente o elemento da denunciação, há uma ideia intrínseca de insídia, que, demagogias à parte, é inerente à

\footnotetext{
11 ARRUDA, Rejane Alves de; PEREIRA, Ricardo Souza. (Org.). Organização Criminosa -
} comentário à lei 12.850/13, de 05 de agosto de 2013. Rio de Janeiro: Lumen Juris, 2013. p. 73. 
própria prática da delação premiada. Este fator característico é inclusive alvo de questionamentos e críticas por parte da doutrina, no que tange a ética e moralidade.

Por outro lado, há também a possibilidade de o acusado, também assumindo a culpa, não incriminar demais pessoas envolvidas no esquema criminoso, mas ainda assim fornecer informações úteis e importantes no âmbito da investigação, com o mesmo intuito de beneficiar-se desse ato. Nesse cenário, o acusado é um mero colaborador, que pode atuar de diversas formas sem necessariamente incriminar terceiros, mas sim utilizar outras variedades da colaboração premiada, que serão examinadas em momento oportuno deste trabalho.

Importante ressaltar que apenas pode-se caracterizar como delação ou colaboração se o investigado assumir a culpa da infração. Se este não assume para si a responsabilidade junto com os quais imputa a prática criminosa, ou seja, negando sua própria participação porém apontando supostos terceiros que teriam cometido tal ato, estamos diante de mero testemunho. Isso ocorre pela própria natureza do instituto. Ora, se o indivíduo jura não ter cometido o crime, não há motivos para estar numa colaboração premiada, para obter benefícios acerca de sanções resultantes de uma ação penal a qual não teria de responder, ou que ao final no mínimo seria declarado inocente.

Não obstante esse caráter de generalidade da colaboração premiada em detrimento da especificidade da delação premiada, o surgimento deu-se de maneira contrária. Isto é, a delação premiada foi a primeira a surgir normativamente; depois, com uma ampliação do entendimento e perícia nas investigações, a evolução do processo penal, bem como da própria sociedade e suas tecnologias, a colaboração premiada foi regulamentada de forma a abranger mais possibilidades ao investigado.

Saindo do plano teórico e partindo para o plano concreto, é de fácil e clara compreensão a diferença apontada. A Lei nº 8.072/90, chamada Lei de 
Crimes Hediondos, foi a primeira em nosso ordenamento a prever a chamada delação premiada, como se verá no capítulo seguinte. O parágrafo único de seu artigo $8^{\circ}$ dispõe que "o participante e o associado que denunciar à autoridade o bando ou quadrilha, possibilitando seu desmantelamento, terá a pena reduzida de um a dois terços".

Observa-se que o benefício de redução de pena o qual a lei previa apenas seria concedido àquele que denunciasse outros integrantes do que a lei chamou de "bando ou quadrilha", sendo esta a única possibilidade para a benesse. É o que podemos chamar de delação premiada.

Por sua vez, a Lei 12.850/13, conhecida como Lei de Crime Organizado, a qual disciplina a colaboração premiada, estabelece "a identificação dos demais coautores e partícipes da organização criminosa e das infrações penais por eles praticadas" (que seria a delação) como apenas uma das cinco possibilidades de colaboração possíveis, segundo os incisos do artigo $4^{\circ}$.

Não é estritamente necessário, portanto, para aplicação do benefício, delatar outras pessoas. Invariavelmente, a imputação de terceiros envolvidos em estrutura criminosa pode advir de outros atos colaborativos, mas não há esta obrigatoriedade. É possível existir a figura do colaboradornão-delator.

Resta claro, então, que a delação premiada é uma das modalidades de colaboração premiada, e está inserida nesta. Segundo Renato Brasileiro de Lima, "a colaboração premiada funciona, portanto, como gênero, do qual a delação premiada seria espécie”.

No mesmo sentido, Luiz Flávio Gomes diferencia os dois institutos:

Não se pode confundir delação premiada com colaboração premiada. Esta é mais abrangente. $\mathrm{O}$ colaborador da justiça pode assumir a culpa e não incriminar outras pessoas (nesse caso, é só colaborador). Pode, de outro lado, assumir a culpa (confessar) e delatar outras pessoas (nessa hipótese é que se fala em delação 
premiada). Em outras palavras: a delação premiada é uma das formas de colaboração com a justiça ${ }^{12}$.

A questão já apareceu no julgado da Apelação Criminal no 20170610089843-DF de relatoria do Desembargador Waldir Leôncio Lopes Júnior, que assim votou:

(...) Inicialmente, convém esclarecer que delação premiada e colaboração premiada não se confundem. Delatar é uma forma de colaborar, mas nem sempre a colaboração decorre de uma delação (...). Assim, em que pesem as expressões delação premiada e colaboração premiada sejam usadas indistintamente, cada uma preceitua uma situação particular, merecendo, portanto, a devida diferenciação ${ }^{13}$.

Inegavelmente, tanto na doutrina como na jurisprudência, e sobretudo na mídia, a expressão "delação premiada" ganhou maior notoriedade e é mais empregada, seja pelo fato de ser a modalidade mais comum e utilizada de colaboração; de teoricamente fornecer maiores resultados práticos; de alguns entendimentos doutrinários tratando-os como sinônimos; ou ainda de simples desconhecimento acerca das demais espécies de colaboração.

Mostra-se incorreto o ligame feito desta forma entre os dois termos, uma vez que tratam-se de institutos semelhantes, porém distintos, conforme pudemos observar. Podemos concluir que toda delação premiada é uma forma de colaboração premiada, mas nem toda colaboração premiada será através da delação premiada.

\subsection{Histórico da Colaboração Premiada}

Embora a origem mais longínqua de que se tem conhecimento do instituto provavelmente remonte à Idade Média, no sistema anglo-saxão, na

\footnotetext{
${ }^{12}$ GOMES, Luiz Flavio. Coordenador e autor responsável. Lei de drogas comentada. $3^{\mathrm{a}}$ ed., São Paulo: RT, 2008. p. 227.

${ }^{13}$ BRASIL. Tribunal de Justiça do Distrito Federal. Apelação Criminal $n^{\circ}$ 20170610089843-DF (0008817-73.2017.8.07.0006). Apelante: Carlos Daniel Araujo Rodrigues. Apelado: Ministério Público do Distrito Federal e Territórios. Rel. Desembargador Waldir Leôncio Lopes Júnior. Brasília, 19 jul. 2018.
} 
qual existia a expressão crown witness (testemunha da coroa), os maiores relatos do início desta prática, no Brasil - àquela época simplesmente a de delação - são acerca do sistema ibérico, com as Ordenações Filipinas, que, desde o século XVII eram aplicadas no sistema brasileiro, ainda subordinado à coroa portuguesa.

A parte criminal do Código Filipino encontrava-se no Livro V, no qual, em seu título CXVI, continha uma ideia embrionária de uma delação premiada, denominada "Como se perdoará aos malfeitores, que derem outros à prisão", transcrito abaixo:

Qualquer pessôa, que der à prisão cada hum dos culpados, e participantes em fazer moeda falsa, ou em cercear, ou per qualquer artifício mingoar, ou corromper a verdadeira, ou em falsar nosso sinal, ou sello, ou da Rainha, ou do Principe meu filho, ou em falsar sinal de algum Vedor de nossa fazenda, ou Dezembargador, ou de outro nosso Official Mór, ou de outros Officiaes de nossa Caza, em cousas, que toquem a seus Officios, ou em matar, ou ferir com bêsta, ou espingarda, matar com peçonha (2), ou em a dar, ainda que morte della se não siga, em matar atraiçoadamente, quebrantar prisões e Cadêas (3) de fóra per força, fazer furto, de qualquer sorte e maneira que seja, pôr fogo acinte para queimar fazenda, ou pessôa, forçar mulher, fazer feitiços, testemunhar falso, em soltar presos por sua vontade, sendo Carcereiro, em entrar em Mosteiro de Freiras com proposito deshonesto, em fazer falsidade em seu Officio, sendo Tabellião, ou Scrivão; tanto que assi der à prisão os ditos malfeitores, ou cada hum delles, e lhes provar, ou forem provados cada hum dos ditos delictos, se esse, que o assi deu à prisão, participante em cada hum dos ditos malefícios, em que he culpado aquelle, que he preso, havemos por bem que, sendo igual na culpa, seja perdoado livremente, postoque não tenha perdão da parte.

E se não fôr participante do mesmo maleficio, queremos que haja perdão para si (tendo perdão das partes) de qualquer maleficio, que tenha, postoque grave seja, e isto não sendo maior daquelle, em que he culpado o que assi deu à prisão.

E se não tiver perdão das partes, havemos por bem de lhe perdoar livremente o degredo, que tiver para Africa, até quatro annos, ou qualquer culpa, ou meleficio, que tiver commettido, porque mereça degredo até os ditos quatro annos.

Porém, isto se entenderá, que o que dér à prisão o malfeitor, não haja perdão de mais pena, nem degredo, que de outro tanto, quanto o malfeitor merecer.

E além do sobredito perdão, que assi outorgamos, nos praz, que sendo o malfeitor, que assi foi dado à prisão, salteador de caminhos, que aquelle, que o 
descobrir, e dér à prisão, e lho provar, haja de Nós trinta cruzados de mercêt ${ }^{14}$ (mantida a ortografia original).

Cumpre ressaltar um ponto interessante nesta sistemática, em que o indivíduo não necessariamente teria de ter participado do crime "delatado", e ainda poderia ser beneficiado, desde que o delito cometido por este não fosse considerado mais grave que a infração que fora delatada. Outro aspecto que chama atenção é uma efetiva "premiação" de trinta cruzados ao "delator".

Esta ideia do Código Filipino como introdutor de uma futura delação premiada, e ainda, colaboração premiada, em nosso ordenamento jurídico foi reconhecida pelo Ministro do Supremo Tribunal Federal Celso de Mello, que, na PET 7.074/DF de 29 de junho de 2017, ligada à Operação Lava Jato, assim asseverou:

\begin{abstract}
A colaboracão premiada, embora em voga no direito processual penal italiano, notadamente a partir de meados da década de 1970, em contexto de combate ao terrorismo (que, em momento subsequente, no início da década de '90, veio a ser utilizada na operação "Mãos Limpas", objetivando a repressão a práticas de corrupção governamental), surgiu, entre nós, no direito reinol, fundada nas Ordenações do Reino (1603), instituída, primariamente, com o objetivo de agraciar aqueles que delatassem os autores e partícipes do crime de falsificação de moeda (Título 116) e, sobretudo, do crime gravíssimo de "lesa-majestade" (Título 6), que constituía o mais sério delito previsto no temível Livro V do Código Filipino, o "liber terribilis", tal a prodigalidade com que esse estatuto legal cominava a pena de morte!!! Na Conjuração Mineira (1789), Joaquim Silvério dos Reis valeu-se desse meio e delatou os inconfidentes de Vila Rica, hoje Ouro Preto, havendo sido beneficiado pela legislação portuguesa consubstanciada, quanto a esse ponto, nas (então) vigentes Ordenações Filipinas! ${ }^{15}$ (grifos originais).
\end{abstract}

O Código Filipino permaneceu vigente no Brasil até 1830, quando foi promulgado o Código Criminal do Império do Brasil, que foi a primeira legislação criminal genuinamente brasileira. Entretanto, não havia mais previsões sobre a delação premiada e assim permaneceria até pouco tempo

\footnotetext{
${ }^{14}$ ALMEIDA, Candido Mendes de. Codigo Philippino ou Ordenações e leis do Reino de Portugal: recopiladas por mandado d'El Rey D. Philippe I. Rio de Janeiro: Typ. Do Instituto Philomathico. 1870. p. 1272.

${ }^{15}$ BRASIL. Supremo Tribunal Federal. Petição $n^{\circ}$ 7.074/DF. Distrito Federal. Relator: Ministro Edson Fachin. DJ: 29 jun. 2017.
} 
atrás, quando, no final do século $\mathrm{XX}$, influenciado por legislações estrangeiras, o direito brasileiro voltou a olhar para esse instituto como uma opção válida e útil.

Duas dessas grandes influências são: (i) os Estados Unidos, com o instituto da plea bargain; e (ii) a Itália, com o chamado pattenggiamento.

O primeiro caso diz respeito ao direito norte-americano, que é dotado de alta permissividade. Devemos atentar para o fato de que o sistema jurídico americano é o da common law, no qual os Promotores dispõem de grande discricionariedade em suas atuações. Essa discricionariedade é tamanha que alguns doutrinadores a entendem como "um absoluto arbítrio com relação à ação penal" ${ }^{\prime \prime}$. Isto posto, a plea bargain surge como uma alternativa de forma a diminuir o número de processos e dar uma tratativa mais célere aos casos, substituindo-os por uma negociação com o acusado, que deve se declarar culpado.

São dois os tipos mais comuns de plea bargain: (i) o charge bargain, que diz respeito à "carga penal", no qual o acusado, após negociação, assume autoria de um crime com pena menor ao qual fora inicialmente acusado; e (ii) o sentence bargain, no qual a sentença é "combinada", ou seja, o acusado e a promotoria chegam a um consenso sobre a sentença que será proposta, e então o acusado se declara culpado ou "não contesta"17.

A decisão final ainda fica com o juiz, que deve analisar os termos da negociação e ver se esta é adequada, mas a verdade é que com a ampla discricionariedade dos promotores, o controle judicial não é muito incisivo.

Este procedimento é amplamente utilizado, de forma que a máquina jurídica dos Estados Unidos está profundamente condicionada a esta

\footnotetext{
16 PASCHOAL, Janaína Conceição. Breves Apontamentos Relativos ao Instituto do 'Plea Bargaining' no Direito Norte-Americano. Revista do Curso de Direito do Centro Universitário das Faculdades Metropolitanas Unidas - UniFMU, ano XV, no 23, 2001. p. 115.

${ }^{17}$ FIND LAW. Plea Bargains: In Depth. Disponível em: https://criminal.findlaw.com/criminalprocedure/plea-bargains-in-depth.html. Acesso em: 21 ago. 2019.
} 
prática, como explica o juiz federal do distrito de Maryland, Peter Messitte, em palestra ministrada no Brasil, em 2017:

Nos EUA, 95\% dos processos terminam em 'plea bargain'. Seria impossível a Justiça norte-americana funcionar sem este instrumento, pois simplesmente não teríamos capacidade de cumprir todas as etapas de cada processo ${ }^{18}$.

Percebe-se, então, uma alta dependência pelo instituto, que foi implantado com o surgimento da ideologia de uma justiça negocial, de forma a conter a grande quantidade de processos que tomaram conta do judiciário americano com a crescente de criminalidade que ocorreu há algumas décadas.

A experiência italiana com essa forma de negociação iniciou por volta da década de 70, quando o governo passou a tratar a situação do terrorismo e das máfias de forma emergencial, visto o crescimento dessas práticas em território italiano. Os delatores eram então chamados de pentiti. Um dos casos mais célebres que merece menção foi a instauração do "maxiprocesso", que em meados da década de 80, tinha a finalidade de apurar os crimes cometidos pela máfia siciliana e acabou por condenar duramente centenas de réus que estavam envolvidos. Naquela oportunidade, o juiz Giovanni Falcone contou com a colaboração do famoso Tommaso Buscetta - mafioso italiano que havia sido capturado no Brasil e extraditado à Itália - para investigar e sentenciar os responsáveis.

O pattenggiamento, por sua vez, surgiu no ano de 1981 em legislação esparsa, e, sendo pouco utilizado, acabou passando por aperfeiçoamentos e voltou a aparecer no Código de Processo Penal de 1988 - que revogou a referida lei - possuindo uma dinâmica muito mais regrada que o plea bargain americano.

\footnotetext{
${ }^{18}$ FUNDAÇÃO FERNANDO HENRIQUE CARDOSO. Delação premiada: uma comparação entre Estados Unidos e Brasil. Disponível em: https://fundacaofhc.org.br/iniciativas/debates/delacao-premiada-uma-comparacao-entre-estadosunidos-e-brasil. Acesso em: 20 ago. 2019.
} 
Uma das principais diferenças entre essas duas figuras é a maior possibilidade de controle judicial no pattenggiamento, uma vez que: (i) incide sobre certos tipos de crime (inicialmente seria cabível a crimes cuja sentença se limitasse a até dois anos, mas, com reforma legislativa em 2003, esse limite subiu para até cinco anos, ambos os prazos após o cômputo da redução de um terço que beneficia o réu); (ii) o Ministério Público deve motivar a recusa; e (iii) o juiz deve homologar o acordo.

Esta diferença é explicada do ponto de vista prático por Vinicius Gomes de Vasconcellos e Bruna Capparelli, em trecho do volume 15 da Revista Eletrônica de Direito Processual da Pós-Graduação da UERJ:

\begin{abstract}
A análise do instituto da aplicação da pena por requisição das partes propicia importantes contribuições à análise crítica dos mecanismos negociais em sistemas processuais continentais. Primeiramente, ponto fulcral do exemplo italiano é a necessidade de motivação da decisão do Ministério Público acerca do cabimento do patteggiamento e as consequências da recusa ilegítima. Em contraste com o modelo estadunidense, cuja ampla discricionariedade do promotor impede amplo controle acerca da barganha, na Itália os motivos da recusa são verificados pelo juiz, que, se entendê-la injustificada, assegurará a redução solicitada pelo acusado, mesmo após o transcorrer de todo o procedimento ordinário $(. . .)^{19}$.
\end{abstract}

Cumpre frisar o elucidado no final do trecho transcrito: "mesmo após o transcorrer de todo o procedimento ordinário". Isso significa que a negociação tem grande prestígio e deverá ser adotada, contanto que homologada pelo juiz. O artigo 445 do Código Processual italiano dispõe que o pactuado entre as partes equivale a uma condenação, permitindo que o juiz suspenda a sentença ${ }^{20}$.

Segundo leciona Ada Pellegrini Grinover, existem três posições que o acusado pode assumir na colaboração premiada do direito italiano:

\footnotetext{
'Arrependido', aquele que antes da sentença condenatória, dissolve ou determina a dissolução da organização criminosa; retira-se da organização, se entrega sem

19 VASCONCELLOS, Vinicius Gomes de. CAPPARELLI, Bruna. Revista Eletrônica de Direito Processual. v. 15. Periódico semestral da pós-graduação stricto sensu em Direito processual da

${ }^{20}$ VAN CLEAVE, Rachel. An Offer You Can't Refuse? Punishment Without Trial in Italy and the United States: The Search for Truth and an Efficient Criminal Justice System. San Francisco, Califórnia, Estados Unidos. 1997. p. 442-443.
} UERJ. 2015. p. 446. 
opor resistência ou abandona as armas, fornece em qualquer caso informações sobre a estrutura e organização da societas celeris, e impede a execução dos crimes para os quais a organização se formou.

'Dissociado', é o que antes da sentença condenatória, se empenha com eficácia para elidir ou diminuir as consequências danosas ou perigosas do crime ou impede a prática de crimes conexos e confessa os crimes cometidos.

'Colaborador', aquele que antes da sentença condenatória, com os comportamentos acima previstos, ajuda as autoridades policiais e judiciárias na colheita de provas decisivas para a individualização e captura de um ou mais autores dos crimes ou fornece elementos de prova relevantes para a exata reconstituição dos fatos e a descoberta dos autores ${ }^{21}$.

Realizando um exercício de direito comparado entre esses dois ordenamentos com o procedimento empregado no Brasil, podemos observar uma aproximação clara entre a colaboração premiada e o pattenggiamento, até pelo fato de ambos os países adotarem o sistema da civil law e serem norteados pelo princípio da indisponibilidade da ação penal.

Entretanto, a contrario sensu, é fácil também afirmar que a colaboração premiada brasileira distancia-se do plea bargain, que possui um regime muito mais amplo e conta com uma liberdade maior do promotor na elaboração dos acordos, bem como os termos nos quais este será ajustado. Isso se dá, entre outros aspectos, pelo Princípio da Oportunidade (ou Conveniência) que rege a sistemática da instauração da ação penal no sistema jurídico americano.

\footnotetext{
${ }^{21}$ GRINOVER. Ada Pellegrini. O crime Organizado no sistema Italiano. RT, 1995. p. 15 apud. GUIDI, José Alexandre Marson. Delação Premiada no combate ao crime Organizado. França Lemos \& Cruz, 2006. p.103-104.
} 


\section{CAPÍTULO 2 - A EVOLUÇÃo DA COLABORAÇÃo PREMIADA NO BRASIL}

Conforme observou-se anteriormente, a colaboração premiada esteve presente na história da humanidade desde os primórdios, e no Brasil, desde antes de sua independência. Ao passar dos anos, o instituto vêm se modificando e se modernizando, especialmente após a Constituição de 1988, na qual passou-se a ter uma ideia mais patente de proteção ao infrator.

Nessa toada, diversas leis que contemplam alguma forma de justiça negocial começaram a surgir no cenário nacional, com o intuito de beneficiar acusados que trouxessem informações úteis ao poder público a fim de ajudar na investigação e persecução penal dos demais envolvidos.

Este capítulo será responsável por ementar todas essas leis que surgiram a partir de 1990 até chegar na legislação mais atual que prevê a aplicação do instituto, de forma a melhor compreender-se a dinâmica adotada nesses anos e as modificações as quais o instituto sofreu até chegar na Lei do Crime Organizado de 2013.

\subsection{Lei 8.072/1990 - Lei de Crimes Hediondos}

A Constituição de 1988 trouxe pela primeira vez a menção aos crimes denominados hediondos, oportunidade na qual, em seu artigo $5^{\circ}$, XLIII, considerou inafiançáveis os delitos desta natureza. Pouco menos de dois anos depois, entraria em vigor a lei 8.072, que teve como finalidade caracterizar tais crimes, bem como editar algumas disposições sobre o cumprimento de pena nesses casos previstos, além de acrescentar e modificar a redação de alguns dispositivos no Código Penal.

Vejamos a lei. $\mathrm{O}$ artigo $7^{\circ}$ acrescentou o seguinte parágrafo ao Código Penal: 
Art. $7^{\circ}$ Ao art. 159 do Código Penal fica acrescido o seguinte parágrafo:

Art. 159 (...) $\S 4^{\circ}$ Se o crime é cometido por quadrilha ou bando, o coautor que denunciá-lo à autoridade, facilitando a libertação do sequestrado, terá sua pena reduzida de um a dois terços ${ }^{22}$.

De forma semelhante, o artigo seguinte dispôs sobre a possibilidade de redução de pena do acusado que incorresse nos crimes hediondos. Veja-se:

Art. $8^{\circ}$ Será de três a seis anos de reclusão a pena prevista no art. 288 do Código Penal, quando se tratar de crimes hediondos, prática da tortura, tráfico ilícito de entorpecentes e drogas afins ou terrorismo.

Parágrafo único. O participante e o associado que denunciar à autoridade o bando ou quadrilha, possibilitando seu desmantelamento, terá a pena reduzida de um a dois terços ${ }^{23}$.

Analisando os transcritos, podemos fazer algumas observações importantes sobre a redação dos dispositivos. Inicialmente, o sujeito a ser beneficiado no primeiro trecho é classificado como "coautor" enquanto o segundo artigo trazido fala em "participante e associado".

Em ambos os casos, para obter a redução da pena, seria necessário "denunciar" à autoridade o grupo, à época denominado de "bando ou quadrilha", de forma que ainda não se possuía a mentalidade nem os atributos técnicos necessários a se pensar numa "organização criminosa" nos moldes que temos hoje. Além disso, tal denúncia deveria "facilitar a libertação do sequestrado" na primeira hipótese; e "possibilitar o desmantelamento" da dita quadrilha ou bando, na segunda hipótese aqui analisada.

Verifica-se então que o embrião da colaboração premiada no ordenamento brasileiro, por esta lei inaugurada, basicamente restringia-se a uma incipiente delação premiada. Ainda que o artigo $7^{\circ}$ pareça encaixar-se

\footnotetext{
${ }^{22}$ BRASIL. Lei $n^{\circ} 8.072$ de 25 de julho de 1990. Dispõe sobre os crimes hediondos, nos termos do art. $5^{\circ}$, inciso XLIII, da Constituição Federal, e determina outras providências. Brasília, DF, 25 jul. 1990.

${ }^{23}$ Ibid., Brasília, DF, 25 jul. 1990.
} 
na hipótese de colaboração para libertação ${ }^{24}$ (que será analisado posteriormente no item 3.1.2) o coautor deveria facilitar a libertação do sequestrado necessariamente por meio da denúncia do bando ou da quadrilha.

Na explicação de Vinicius Gomes de Vasconcellos, inicialmente a doutrina caracterizava o instituto como possuindo uma natureza penal material, de forma que posteriormente esse conceito mudou, mormente com o advento da Lei do Crime Organizado em 2013:

Isso ocorreu em razão da postura adotada pelo legislador brasileiro no sentido de prever o instituto, seus requisitos e consequências, mas não o seu procedimento em caráter processual.[...] Entretanto, tal cenário foi profundamente alterado pela Lei 12.850/13, diploma normativo que trata, quase que exclusivamente, de matéria processual, introduzindo espaços de não obrigatoriedade (como o art. $4^{\circ}$, $\S 4^{\circ}$ ) e benefícios concedidos a partir de lógica de direito adjetivo, além de um regramento mais detalhado do procedimento a ser adotado ${ }^{25}$.

Fica claro que o legislador pouco preocupou-se com a delimitação procedimental ou as consequências dessa colaboração no curso do processo, o que tentou se corrigir nos últimos diplomas legais que versam sobre o tema. Importante também mencionar que estas previsões ainda encontramse vigentes.

\subsection{Lei $8.137 / 1990$ - Lei dos Crimes Contra a Ordem Tributária, Econômica e Relações de Consumo}

A Lei $\mathrm{n}^{\circ}$ 8.137, do mesmo ano, trouxe conceituações acerca dos crimes que atentam contra a ordem tributária, a ordem econômica e as relações de consumo. As inspirações vieram do então recém-promulgado Código de Defesa do Consumidor, norteado pela ideologia surgida à época de maior proteção ao consumidor, bem como a necessidade de maior arrecadação tributária.

\footnotetext{
${ }^{24}$ Nesse sentido: ARAS, Vladimir. Lavagem de dinheiro: prevenção e controle penal. CARLI, Carla Veríssimo de (Org.). Porto Alegre: Editora Verbo Jurídico, 2011. p. 427.

${ }^{25}$ VASCONCELLOS, Vinicius Gomes de. Colaboração Premiada no Processo Penal. São Paulo: Thomson Reuters, 2018. p. 60-61.
} 
Da mesma forma que os dispositivos analisados no item anterior, o artigo 16, parágrafo único, desta lei, disciplinou, de forma muito semelhante, a redução de pena para o colaborador:

Art. 16. Qualquer pessoa poderá provocar a iniciativa do Ministério Público nos crimes descritos nesta lei, fornecendo-lhe por escrito informações sobre o fato e a autoria, bem como indicando o tempo, o lugar e os elementos de convicção.

Parágrafo único. Nos crimes previstos nesta Lei, cometidos em quadrilha ou coautoria, o coautor ou partícipe que através de confissão espontânea revelar à autoridade policial ou judicial toda a trama delituosa terá a sua pena reduzida de um a dois terços ${ }^{26}$.

Chama atenção a aparição da expressão "confissão espontânea" que não era explícita nos dispositivos citados anteriormente, assegurando um dos requisitos primordiais da colaboração, conforme se verifica nos moldes atuais.

Atente-se que tal parágrafo fora introduzido pela Lei $\mathrm{n}^{\circ} 9.080$ de julho 1995, ou seja, cinco anos depois da promulgação da original e poucos meses antes da Lei $\mathrm{n}^{\circ}$ 9.099, que trouxe o já conhecido instituto flexibilizador da suspensão condicional do processo (sursis processual) evidenciando uma orientação do legislador no sentido de aumentar as possibilidades de negociações inter partes na persecução penal.

Importante salientar que a lei tratada neste item surgiu quase que simultaneamente à Lei $\mathrm{n}^{\circ}$ 9.034, a antiga Lei do Crime Organizado (que será tratada a seguir), antecessora da afamada Lei $\mathrm{n}^{\mathbf{0}} 12.850 / 13$, objeto principal deste trabalho, que será posteriormente analisada em capítulo apartado.

${ }^{26}$ BRASIL. Lei $n^{o} 8.137$ de 27 de dezembro de 1990. Define crimes contra a ordem tributária, econômica e contra as relações de consumo, e dá outras providências. Brasília, DF, 27 dez. 1990. 


\subsection{Lei 9.034/1995 - Antiga Lei do Crime Organizado (Revogada)}

A Lei $n^{\circ} 9.034$ de 1995 foi a primeira em nosso ordenamento que tratou da matéria da organização criminosa. No seu escopo, a lei ocupou-se em descrever de forma tímida as atividades criminosas praticadas de forma organizada, mencionava alguns meios de produção de prova e de procedimentos investigativos. Faz alusão também à colaboração premiada, conforme será visto a seguir.

Mas, infelizmente, o legislador não foi feliz na edição desta norma, de maneira que a Lei pouco agregou no cenário jurídico, muito pela flagrante deficiência no conteúdo dos seus dispositivos. Luiz Flávio Gomes, em 2002 (portanto antes da edição da atual Lei de Crime Organizado) ressaltou a ineficiência das normas que existiam até então em conceituar tais institutos e incentivar suas aplicações na prática:

[...] cuida-se, portanto, de um conceito vago, totalmente aberto, absolutamente poroso. Considerando-se que (diferentemente do que ocorria antes) o legislador não ofereceu nem sequer a descrição típica mínima do fenômeno, só nos resta concluir que, nesse ponto, a lei (9.034/95) passou a ser letra morta. Organização criminosa, portanto, hoje, no ordenamento jurídico brasileiro, é uma alma (uma enunciação abstrata) em busca de um corpo (de um conteúdo normativo, que atenda o princípio da legalidade). Se as leis do crime organizado no Brasil (Lei 9.034/95 e Lei 10.217/01), que existem para definir o que se entende por organização criminosa, não nos explicaram o que é isso, não cabe outra conclusão: desde 12.04.01 perderam eficácia todos os dispositivos legais fundados nesse conceito que ninguém sabe o que é. São eles: arts. $2^{\circ}$, inc. II (flagrante prorrogado), $4^{\circ}$ (organização da polícia judiciária), $5^{\circ}$ (identificação criminal), $6^{\circ}$ (delação premiada), $7^{\circ}$ (proibição de liberdade provisória) e $10^{\circ}$ (progressão de regime) da Lei 9.034/95, que só se aplicam para as (por ora, indecifráveis) organizações criminosas ${ }^{27}$.

Conforme citado acima, o artigo que versa sobre a colaboração premiada é o artigo $6^{\circ}$, que reza:

\footnotetext{
${ }^{27}$ GOMES, Luiz Flávio. Crime organizado: que se entende por isso depois da Lei $n^{\circ} 10.217 / 01$ ? Apontamentos sobre a perda de eficácia de grande parte da Lei 9.034/95. Jus Navigandi, Teresina, ano 7, n. 56, 1 abr. 2002. Disponível em: http://jus.com.br/artigos/2919. Acesso em: 30 ago. 2019.
} 
Art. $6^{\circ}$ Nos crimes praticados em organização criminosa, a pena será reduzida de um a dois terços, quando a colaboração espontânea do agente levar ao esclarecimento de infrações penais e sua autoria ${ }^{28}$.

Primeiramente é importante destacar que, muito embora o prestigiado professor Luiz Flávio Gomes utilize o termo delação premiada, ainda que o trecho seja datado anteriormente ao advento da Lei $n^{o}$ $12.850 / 13$, que trouxe o conceito de colaboração premiada, parece mais assertivo a utilização deste segundo termo, haja vista que pela primeira vez o legislador fez uma dissociação entre uma colaboração quase que indeterminada - "esclarecimento de infrações penais" - e a delação propriamente dita - "e sua autoria” - como já foi visto no início deste trabalho, quando tratou-se da diferenciação dos dois termos.

Feita esta prévia explicação, passemos agora a analisar criticamente o diploma legal apresentado.

Em sentido amplo, a lei falha em conceituar a figura da organização criminosa, de maneira que, em nenhum dos seus pouco mais de 10 artigos, preocupou-se em definir de maneira concreta o que viria a ser efetivamente uma organização criminosa e quem viria a ser o integrante desta. Não só isso, mas também falhou ao não estabelecer limites e diretrizes procedimentais no tocante a alguns aspectos investigativos, bem como a colaboração premiada.

Em sentido estrito, averiguando o artigo $6^{\circ}$, sua escrita acabou por gerar dúvidas quanto a necessidade da voluntariedade da colaboração premiada, de forma que levantou-se essa discussão entre autores e operadores do direito. Uma vez o dispositivo insere a condicionalidade ao dizer a pena será reduzida "quando a colaboração espontânea do agente levar ao esclarecimento de infrações penais e sua autoria" passou-se a questionar se a colaboração poderia ser de outra forma que não

\footnotetext{
${ }^{28}$ BRASIL. Lei $n^{o} 9.034$ de 3 de maio de 1995. Dispõe sobre a utilização de meios operacionais para a prevenção e repressão de ações praticadas por organizações criminosas. Brasília, DF, 3 mai. 1995.
} 
espontânea ${ }^{29}$, e se esse caso fosse possível, quais benefícios o colaborador teria direito. Veja-se que à época o instituto ainda não era difundido como nos dias atuais, quando sabemos claramente que a voluntariedade é requisito essencial para a validade da celebração de um acordo de colaboração premiada.

A Lei $\mathrm{n}^{\circ} 9.034 / 95$, antiga lei do crime organizado, foi inteiramente revogada de maneira expressa pela Lei $\mathrm{n}^{\circ} 12.850$ de 2013.

\subsection{Lei $9.613 / 1998$ - Lei de Lavagem de Bens e Capitais}

A Lei de Lavagem de Bens e Capitais é de grande importância para o refinamento do instituto. Desde 1998, tal lei previa também a possibilidade de certos benefícios àquele que decidisse colaborar com as autoridades no transcorrer da persecução. Aliás, não só previa o mesmo benefício que todas as legislações anteriores previam (a redução da sanção penal de um a dois terços), como estendeu as formas de beneficiar o colaborador. Em sua redação original, o parágrafo $5^{\circ}$ do artigo $1^{\circ}$ previa o seguinte:

$\S 5^{\circ}$ A pena poderá ser reduzida de um a dois terços e começará a ser cumprida em regime aberto, podendo o juiz deixar de aplicá-la ou substituí-la por pena restritiva de direitos, se o autor, coautor ou partícipe colaborar espontaneamente com as autoridades, prestando esclarecimentos que conduzam à apuração das infrações penais e de sua autoria ou à localização dos bens, direitos ou valores objeto do crime ${ }^{30}$.

Como nos demais casos, vemos que, ainda que haja uma evolução normativa, o instituto ainda carecia de maiores instruções técnicas acerca do procedimento a ser adotado quando da feitura do acordo de colaboração premiada.

\footnotetext{
${ }^{29}$ VASCONCELLOS, 2018, p. 78.

${ }^{30}$ BRASIL. Lei $n^{\circ} 9.613$ de 3 de março de 1998. Dispõe sobre os crimes de "lavagem" ou ocultação de bens, direitos e valores; a prevenção da utilização do sistema financeiro para os ilícitos previstos nesta Lei; cria o Conselho de Controle de Atividades Financeiras - COAF, e dá outras providências. Brasília, DF, 3 mar. 1998.
} 
Em 2003, o então senador Antonio Carlos Valadares apresentou o Projeto de Lei n 209 que modificaria a Lei de Lavagem de Bens e Capitais, objetivando uma maior eficiência no combate a estes tipos penais. A redação final que fora aprovada pelo plenário do Senado Federal continha algumas alterações significativas e que serviriam de baliza no método da realização dos acordos da então denominada "colaboração espontânea"31:

$\S 5^{\circ}$ A pena poderá ser reduzida de um a dois terços e ser cumprida em regime aberto ou semiaberto, facultando-se ao juiz deixar de aplicá-la ou substituí-la, a qualquer tempo, por pena restritiva de direitos, se o autor, coautor ou partícipe colaborar espontaneamente com as autoridades, prestando esclarecimentos que conduzam à apuração das infrações penais, à identificação dos autores, coautores e partícipes, ou à localização dos bens, direitos ou valores objeto do crime.

$\S 6^{\circ} \mathrm{Na}$ hipótese do $\S 5^{\circ}$ deste artigo, não se lavrará termo nos autos da negociação autorizada pelo juiz e referendada pelo Ministério Público, devendo constar de termo separado e mantido sob sigilo.

$\S 7^{\circ} \mathrm{O}$ acordo de que tratam os $\S \S 5^{\circ}$ e $6^{\circ}$ deste artigo, se cumprido, obrigará a sentença aos seus termos ${ }^{32}$.

Tal proposta gerou certo otimismo em parte da doutrina entusiasta do instituto, como o Procurador da República Celso Costa Leal evidenciou:

Até o momento não existe qualquer regulamentação legal do procedimento a ser adotado. Experiências bem sucedidas em muito contribuíram, mas uma lei adequada sobre o tema faz falta, até mesmo como forma de uniformização do procedimento adotado.

Ao que tudo indica, o Projeto de Lei n. 209 do Senado Federal será aprovado e com ele a sonhada regulamentação da matéria. O crime organizado está em constante modernização e, a cada momento, novas formas de crimes são implementadas. A Justiça e os órgãos de persecução penal têm igualmente que se modernizarem e desenvolverem novas formas de combate ao crime ${ }^{33}$.

\footnotetext{
${ }^{31}$ Nesse sentido: VASCONCELLOS, 2018, p. 79.

32 BRASIL. Projeto de Lei $n^{\circ}$ 209, de 2003 (do Senado Federal). Dá nova redação a dispositivos da Lei $\mathrm{n}^{\circ}$ 9.613, de 3 mar. 1998, objetivando tornar mais eficiente a persecução penal dos crimes de lavagem de dinheiro. Brasília, DF, 8 mai. 2008. Disponível em: https://www25.senado.leg.br/web/atividade/materias/-/materia/58211. Acesso em: 02 set. 2019.

${ }^{33}$ LEAL, Celso Costa Lima Verde. Aspectos procedimentais da delação premiada e a nova lei de lavagem de dinheiro. In: Capacitar. VII Curso de ingresso e vitaliciamento para Procuradores da República. Brasília: ESPMU, 2011.p. 62.
} 
Após tramitar na Câmara dos Deputados como Projeto de Lei $n^{\circ}$ 3.443 a partir de 2008 , foi finalmente transformado na Lei $\mathrm{n}^{\circ} 12.683 \mathrm{em}$ julho de 2012. Ocorre que os parágrafos $6^{\circ}$ e $7^{\circ}$, que haviam sido acrescidos pelo Senado inicialmente, foram suprimidos e não apareceram na redação final que tornou-se lei. Destarte, a regulamentação do procedimento a ser adotado - ainda que não tivesse recebido, mesmo no PL 209, a atenção que de fato merece - foi novamente deixada de lado pelo legislador.

Por outro lado, com a mudança do texto do $§ 5^{\circ}$, houve progresso em relação às formas de colaboração possíveis: a) esclarecimentos que conduzam à apuração das infrações penais; b) identificação dos autores, coautores e partícipes; e c) localização dos bens, direitos ou valores objeto do crime, confirmando a tendência de abarcar diversas formas de colaboração, e não somente a delação.

Outro ponto interessante que a reforma trouxe foi a inserção do trecho "a qualquer tempo", o que tornou possível a concessão do benefício a qualquer momento, dilatando o momento possível para a celebração do acordo de colaboração inclusive para a execução penal, aspecto que não havia sido regido por nenhuma legislação anterior.

\subsection{Lei 9.807/1999 - Lei de Proteção a Vítimas e Testemunhas}

Até este dado momento, o ordenamento jurídico brasileiro não previa maiores proteções ao colaborador, o que, para alguns juristas, foi motivo que levou a uma pouca aplicabilidade do instituto. A Lei $\mathrm{n}^{\circ} 9.807$ surgiu antes da virada do século para suprir essa necessidade de proteção da integridade física do colaborador, bem como de sua família. É bem da verdade que o diploma legal não esgota o tema como deveria, tanto na regulação do procedimento em si, como na própria seara da proteção ao colaborador. 
Uma grande diferença em relação às demais leis, é que esta difunde o instituto da colaboração premiada. Ao passo que as normativas anteriores conferiam a possibilidade de celebração de acordos de colaboração premiada adstrita aos crimes específicos nelas previstos, a Lei de Proteção a Vítimas e Testemunhas é uma lei de caráter geral que também disciplina o instituto, expandindo assim, seu campo de aplicação.

A redação da Lei $n^{\circ} 9.807$ relacionada à colaboração premiada, que está localizada no capítulo II - "Da proteção aos réus colaboradores”, pode ser dividida em duas partes: a primeira, dos artigos 13 e 14, é a parte que regra o instituto em si, com as possibilidades e requisitos de aplicação para obter os prêmios, indo de concessão de perdão judicial à redução de pena, respectivamente:

Art. 13. Poderá o juiz, de ofício ou a requerimento das partes, conceder o perdão judicial e a consequente extinção da punibilidade ao acusado que, sendo primário, tenha colaborado efetiva e voluntariamente com a investigação e o processo criminal, desde que dessa colaboração tenha resultado:

I - a identificação dos demais coautores ou partícipes da ação criminosa;

II - a localização da vítima com a sua integridade física preservada;

III - a recuperação total ou parcial do produto do crime.

Parágrafo único. A concessão do perdão judicial levará em conta a personalidade do beneficiado e a natureza, circunstâncias, gravidade e repercussão social do fato criminoso.

Art. 14. O indiciado ou acusado que colaborar voluntariamente com a investigação policial e o processo criminal na identificação dos demais coautores ou partícipes do crime, na localização da vítima com vida e na recuperação total ou parcial do produto do crime, no caso de condenação, terá pena reduzida de um a dois terços ${ }^{34}$.

\footnotetext{
${ }^{34}$ BRASIL. Lei $n^{\circ} 9.807$ de $13 \mathrm{jul}$. 1999. Estabelece normas para a organização e a manutenção de programas especiais de proteção a vítimas e a testemunhas ameaçadas, institui o Programa Federal de Assistência a Vítimas e a Testemunhas Ameaçadas e dispõe sobre a proteção de acusados ou condenados que tenham voluntariamente prestado efetiva colaboração à investigação policial e ao processo criminal. Brasília, DF, 13 jul. 1999.
} 
A segunda parte deste capítulo II é a que efetivamente veio para tratar sobre a proteção ao colaborador, no artigo 15 e parágrafos seguintes da lei:

Art. 15. Serão aplicadas em benefício do colaborador, na prisão ou fora dela, medidas especiais de segurança e proteção a sua integridade física, considerando ameaça ou coação eventual ou efetiva.

$\S 1$ 1o Estando sob prisão temporária, preventiva ou em decorrência de flagrante delito, o colaborador será custodiado em dependência separada dos demais presos.

$\S 2$ o Durante a instrução criminal, poderá o juiz competente determinar em favor do colaborador qualquer das medidas previstas no art. 8 o desta Lei.

$\S 30$ No caso de cumprimento da pena em regime fechado, poderá o juiz criminal determinar medidas especiais que proporcionem a segurança do colaborador em relação aos demais apenados ${ }^{35}$.

Observa-se que o texto, sobretudo o caput do art. 15, deu algumas soluções generalizadas para a situação em que o colaborador necessite de amparo, enquanto os parágrafos $1^{\circ}$ e $3^{\circ}$ previram algumas situações mais específicas. Com essas mudanças, o legislador esperou incentivar ainda mais a utilização destas práticas, tanto por parte dos colaboradores, que estariam mais resguardados; quanto por parte das autoridades, revestidas de um pouco mais de segurança jurídica e conhecimento técnico.

\subsection{Lei 10.409/2002 e Lei 11.343/2006 - Leis de Drogas}

A lei $n^{\circ} 10.409$ surgiu em 2002 para combater os crimes ligados à entorpecentes, e foi mais uma legislação que previu em sua composição a figura do réu colaborador, mais especificamente no capítulo IV, intitulado "Do procedimento penal". Apesar de vigorar por um breve tempo, a metodologia adotada neste âmbito foi a mais completa em termos de detalhes procedimentais e a que mais se assemelha ao sistema que temos na

\footnotetext{
${ }^{35}$ BRASIL. Lei $n^{\circ} 9.807$ de 13 jul. 1999. Brasília, DF, 13 jul. 1999.
} 
Lei $n^{\circ} 12.850$. Assim diziam os parágrafos $2^{\circ}$ e $3^{\circ}$ do artigo 32 da referida lei:

$\S 2^{\circ} \mathrm{O}$ sobrestamento do processo ou a redução da pena podem ainda decorrer de acordo entre o Ministério Público e o indiciado que, espontaneamente, revelar a existência de organização criminosa, permitindo a prisão de um ou mais dos seus integrantes, ou a apreensão do produto, da substância ou da droga ilícita, ou que, de qualquer modo, justificado no acordo, contribuir para os interesses da Justiça.

$\S 3^{\circ} \mathrm{Se}$ o oferecimento da denúncia tiver sido anterior à revelação, eficaz, dos demais integrantes da quadrilha, grupo, organização ou bando, ou da localização do produto, substância ou droga ilícita, o juiz, por proposta do representante do Ministério Público, ao proferir a sentença, poderá deixar de aplicar a pena, ou reduzi-la, de 1/6 (um sexto) a 2/3 (dois terços), justificando a sua decisão ${ }^{36}$.

Alguns comentários sobre ambos dispositivos supracitados merecem ser feitos: primeiramente, este foi o primeiro de diploma que tratou a colaboração como uma negociação entre as partes (réu e Ministério Público).

Em segundo lugar, o final do parágrafo $2^{\circ}$ deixa em aberto as formas de se "contribuir para os interesses da Justiça"; não se restringindo nem somente à delação premiada, nem às maneiras elencadas no dispositivo; mas dando liberdade às partes para acordarem sobre eventuais formas diversas de contribuição não previstas, que, nada obstante, poderiam ser ajustadas num acordo de colaboração premiada.

Por último, mas não menos importante, o parágrafo $3^{\circ}$ ainda veio disciplinar o tema numa ótica procedimental, baseado na temporalidade da celebração do acordo e na atuação do Ministério Público.

Todavia, em 2006 essa lei foi substituída pela Lei $n^{\circ} 11.343$, a Nova Lei de Drogas, que manteve o réu colaborador em seu artigo 41, porém com consideráveis mudanças:

\footnotetext{
${ }^{36}$ BRASIL. Lei $n^{\circ} 10.409$ de 11 de janeiro de 2002. Dispõe sobre a prevenção, o tratamento, a fiscalização, o controle e a repressão à produção, ao uso e ao tráfico ilícitos de produtos, substâncias ou drogas ilícitas que causem dependência física ou psíquica, assim elencados pelo Ministério da Saúde, e dá outras providências. Brasília, DF, 11 jan. 2002.
} 
Art. 41. O indiciado ou acusado que colaborar voluntariamente com a investigação policial e o processo criminal na identificação dos demais coautores ou partícipes do crime e na recuperação total ou parcial do produto do crime, no caso de condenação, terá pena reduzida de um terço a dois terços ${ }^{37}$.

À primeira vista já podemos perceber que o tema, que havia sido tratado em dois dispositivos anteriormente, fora abreviado em apenas um artigo. Além disso, a espécie premial de perdão judicial também não foi repetida nesse texto, caracterizando uma real diminuição de incentivo por parte da lei.

Focando-se no texto em si, outra diferença notável é na própria redação. Enquanto sua predecessora, nos parágrafos $2^{\circ}$ e $3^{\circ}$ previa requisitos alternativos, a lei de 2006 dá a entender que os requisitos são cumulativos. Porém, ainda assim, a interpretação mais correta é a de não cumulatividade, como se extraía da normativa anterior. Assim lecionam Paulo Roberto Galvão Carvalho e Andrey Borges de Mendonça:

\begin{abstract}
Apesar da conjunção aditiva, nada impede que o magistrado aplique a causa de redução se o agente tiver delatado apenas quem são os demais partícipes da empreitada criminosa ou apenas onde se encontra a droga, dentro de suas possibilidades. Isto porque, em determinadas hipóteses, o agente não saberá onde se encontra o produto do crime ou, ainda, porque este já foi recuperado ou, ao contrário, saberá onde se encontra o produto do crime, mas não terá possibilidade de identificar os demais autores e partícipes ${ }^{38}$.
\end{abstract}

Resta claro, portanto, que o legislador foi profundamente infeliz nessa transição da Lei de Drogas no que tange o instituto da colaboração premiada. É evidente o retrocesso, que simplesmente faz alusão às legislações ultrapassadas, com conteúdo técnico escasso e esclarecimentos procedimentais nulos, numa redação pobre e defeituosa, retornando à maior

\footnotetext{
37 BRASIL. Lei $n^{\circ} 11.343$ de 23 de agosto de 2006. Institui o Sistema Nacional de Políticas Públicas sobre Drogas - Sisnad; prescreve medidas para prevenção do uso indevido, atenção e reinserção social de usuários e dependentes de drogas; estabelece normas para repressão à produção não autorizada e ao tráfico ilícito de drogas; define crimes e dá outras providências. Brasília, DF, 23 ago. 2006.

${ }^{38}$ CARVALHO, Paulo Roberto Galvão; MENDONÇA, Andrey Borges de. Lei de Drogas: Lei 11.343 de 23 de agosto de 2006 - Comentada artigo por artigo. São Paulo: Método, 2012. p. 191.
} 
importância para a perspectiva material do instituto conforme o ordenamento costumava dar anteriormente. 


\section{CAPÍTULO 3 - O SISTEMA DA LEI 12.850/2013 - LEI DE CRIME ORGANIZADO}

Conforme visto no capítulo anterior, a colaboração premiada, ainda que com denominações distintas ao passar dos anos, não era novidade no Brasil. Desde a década de 90 possuíamos leis que previam institutos precursores do que hoje conhecemos como colaboração premiada.

Entretanto, como já bem observado, embora a figura da colaboração premiada existisse, não resta dúvida que esta carecia de maior atenção por parte do legislador. Não é possível falar numa regulamentação satisfatória sobre o procedimento, nem em um regramento detalhado como se deveria ter até pouco tempo atrás, quando do surgimento da Lei ${ }^{\circ} 12.850$.

Não há como negar que tal norma é bem-vinda. A lei inovou, trazendo aspectos procedimentais de forma a tentar sanar as lacunas deixadas por regramentos insuficientes que pretenderam, sem sucesso, tratar do tema no passado. Buscou-se abarcar a perspectiva de todos os personagens envolvidos. Nas palavras de Renato Brasileiro:

Daí a importância da nova Lei das Organizações Criminosas: sem descuidar da proteção dos direitos e garantias fundamentais do colaborador(...), a Lei 12.850/13 passa a conferir mais eficácia à medida sob comento, seja por regulamentar expressamente a celebração do acordo de colaboração premiada, dispondo sobre a legitimidade para a proposta, conteúdo do acordo e necessária homologação judicial, seja por prever expressamente que nenhuma sentença condenatória poderá ser proferida com fundamento apenas nas declarações do colaborador $^{39}$.

Analisando-se a lei, verificamos já no artigo $1^{\circ}$ a preocupação em corrigir definitivamente um dos que tinham sido um dos maiores equívocos da antiga Lei de Crime Organizado, responsável por boa parte das críticas que recebeu: a falta de conceituação do principal elemento que a Lei regrava. Dessa forma, o capítulo I - "Da organização criminosa" incumbe-

\footnotetext{
${ }^{39}$ LIMA, Renato Brasileiro de. Manual de Processo Penal. Salvador: Juspodivm, 2018. p. 802.
} 
se de definir organização criminosa, outros grupos que equiparam-se a ela para os efeitos legais, as penas aplicáveis, e algumas disposições de cunho processual. De modo a melhor compreender o desígnio do diploma legal e o âmago ao qual se insere o objeto de estudo deste trabalho, observemos o artigo $1^{\circ}$ e o parágrafo $1^{\circ}$ da Lei $12.850 / 13$ :

Art. $1^{\circ}$ Esta Lei define organização criminosa e dispõe sobre a investigação criminal, os meios de obtenção da prova, infrações penais correlatas e o procedimento criminal a ser aplicado.

$\S 1^{\circ}$ Considera-se organização criminosa a associação de 4 (quatro) ou mais pessoas estruturalmente ordenada e caracterizada pela divisão de tarefas, ainda que informalmente, com objetivo de obter, direta ou indiretamente, vantagem de qualquer natureza, mediante a prática de infrações penais cujas penas máximas sejam superiores a 4 (quatro) anos, ou que sejam de caráter transnacional ${ }^{40}$.

O capítulo II - "Da investigação e dos meios de obtenção de prova" por sua vez, como o enunciado já dá a entender, traz um rol dos possíveis meios de obtenção de provas que são permitidos. A colaboração premiada aparece logo no inciso I, o que corrobora com a natureza jurídica atribuída ao instituto, em discussão já devidamente tratada no início deste texto.

Outro aspecto que merece destaque é a primeira parte do art. $3^{\circ}$, que deixa bem claro que um acordo de colaboração premiada pode ser constituído "em qualquer fase da persecução penal". Isso abre imensas possibilidades, uma vez que o conteúdo desse acordo moldar-se-á segundo as circunstâncias em que as partes estarão, e a fase da persecução pode influenciar substancialmente nesta questão.

Num primeiro olhar, temos a tendência de imaginar que o acordo de colaboração premiada somente seria aplicável na fase investigativa, pré processual; ou ainda, no máximo, até o fim da instrução probatória, dada sua própria natureza jurídica de meio de obtenção de prova. De fato, o mais

\footnotetext{
${ }^{40}$ BRASIL. Lei $n^{\circ} 12.850$ de 11 de janeiro de 2002. Dispõe sobre a prevenção, o tratamento, a fiscalização, o controle e a repressão à produção, ao uso e ao tráfico ilícitos de produtos, substâncias ou drogas ilícitas que causem dependência física ou psíquica, assim elencados pelo Ministério da Saúde, e dá outras providências. Brasília, DF, 11 de janeiro de 2002.
} 
comum é que as tratativas sejam feitas no início da persecução penal, para que, com ulterior homologação do juiz, o recebimento da denúncia e consequentemente o início da fase processual, ocorra a efetiva produção de provas.

Não obstante, devemos reconhecer a possibilidade da celebração do acordo desde a fase de investigação preliminar até a execução penal, mesmo após o trânsito em julgado de eventual sentença condenatória (desde que a colaboração ainda seja plenamente eficaz). Para Andrey Borges de Mendonça, o acordo poderá ser celebrado em todas as fases, seja ela pré processual, processual ou pós processual, já que "mais importante do que o momento é a efetiva contribuição para a persecução de infrações penais graves" ${ }^{41}$.

\subsection{Espécies de Colaboração Premiada}

No item 1.2 deste trabalho buscou-se, de forma clara, realizar uma diferenciação entre a colaboração premiada e delação premiada. Para isso, foi mostrado que a colaboração não necessariamente deverá estar ligada ao ato de delatar terceiros envolvidos, muito embora essa talvez ainda seja a forma mais comumente utilizada por colaboradores. Nesta parte, serão apresentadas tais subespécies e quais os possíveis resultados cada uma pretende atingir, que por sua vez estão elencados nos incisos I a $\mathrm{V}$ do artigo $4^{\circ}$ da Lei $12.850 / 13$.

Seja qual for a espécie adotada, o $\S 1^{\circ}$ do artigo $4^{\circ}$ disciplina que "a concessão do benefício levará em conta a personalidade do colaborador, a natureza, as circunstâncias, a gravidade e a repercussão social do fato criminoso e a eficácia da colaboração". Esses fatores serão diferentes em casa caso, podendo influenciar na forma de colaboração que será feita, conforme veremos a seguir.

\footnotetext{
${ }^{41}$ MENDONÇA, Andrey Borges de. A colaboração premiada e a nova Lei do Crime Organizado (Lei 12.850/13). Revista Custos Legis, v. 04, 2013. p. 7.
} 
Amparado por algumas legislações anteriores que já remavam nesse sentido de ampliar as formas possíveis de colaboração, Vladimir Aras distinguiu quatro subespécies da colaboração premiada ${ }^{42}$, demonstradas a seguir.

\subsubsection{A Delação Premiada}

Também denominada chamamento de corréu, essa é a modalidade na qual o colaborador, além de confessar sua participação no delito, informa quais outras pessoas também estão envolvidas. Alguns autores chamam o colaborador adepto a esta espécie de "agente revelador" pelo fato deste expor terceiros que contribuíam no esquema da ação criminosa, seus atos ilícitos e sua organização (assegurando a continuidade e hierarquia do grupo, visando o êxito da operação).

Nesse sentido, sobrevém a conceituação do ilustre professor Fernando Capez:

Delação ou chamamento de corréu é a atribuição de prática do crime a terceiro, feita pelo acusado em seu interrogatório, e pressupõe que também o delator confesse a sua participação ${ }^{43}$.

Essa espécie está atrelada aos incisos I e II do parágrafo $4^{\circ}$ da Lei 12.850, que preveem como possíveis resultados da colaboração premiada "a identificação dos demais coautores e partícipes da organização criminosa e das infrações penais por eles praticadas" e "a revelação da estrutura hierárquica e da divisão de tarefas da organização criminosa".

Dada a redação dos incisos, podemos extrair duas informações: a primeira, em relação ao inciso I, como o legislador utilizou a expressão "demais coautores e partícipes" fica claro que para fazer jus ao benefício, o

\footnotetext{
${ }^{42}$ ARAS, 2011, p. 427.

${ }^{43}$ CAPEZ, Fernando. Curso de direito penal: parte geral: v. 1. 16 ed., São Paulo: Saraiva, 2012.
} 
delator deve fornecer informações sobre os demais envolvidos na prática criminosa em concurso de agentes, que é objeto do processo.

A segunda, em relação ao inciso II, diz respeito à hierarquia e organização. Conforme visto acima, o artigo $1^{\circ}$ define que um dos elementos para a identificação do grupo como organização criminosa é ser uma associação com no mínimo quatro pessoas, numa estrutura "ordenada e caracterizada pela divisão de tarefas". Com isso, foi dada importância à obtenção de informações sobre as tarefas atribuídas a cada integrante, de forma a facilitar seu estudo, para por fim, conseguir seu desmonte.

Provavelmente esta seja a espécie mais efetiva no sentido de desmantelamento das organizações criminosas, de forma que as autoridades conseguiriam mais celeridade e possibilidade de êxito ao terem alvos certeiros para investigar.

\subsubsection{A Colaboração Preventiva}

Nesta modalidade, como o próprio nome sugere, o colaborador dá aos órgãos responsáveis informações de forma a evitar um crime ou cessar a continuidade de uma atividade ilícita. O inciso III prevê como um dos possíveis resultados da colaboração "a prevenção de infrações penais decorrentes das atividades da organização criminosa".

Esta hipótese tem uma peculiaridade, que é a inversão da ordem padrão do que geralmente se tem na colaboração. Ao invés do colaborador indicar crimes já consumados, tal modalidade prevê a prestação de informações sobre atos criminosos que ainda virão a ocorrer, os quais muito provavelmente as autoridades não tomariam conhecimento sem o auxílio do colaborador. Por essa razão, trata-se de uma forma importante e bastante interessante de colaboração que a Lei 12.850 consagrou.

Com essas informações, os órgãos responsáveis pela segurança pública e também pela persecução penal ficariam "um passo a frente", 
podendo impedir a consumação de delitos de forma inteligente e estratégica, utilizando ainda outras ferramentas do nosso ordenamento que contribuem para um sistema preventivo e não apenas repressivo, como exemplo do flagrante esperado, ou ainda o flagrante diferido ${ }^{44}$.

\subsubsection{A Colaboração para Localização e Recuperação de Ativos}

Nesta hipótese bem específica, o colaborador exerce seu papel ao comunicar às autoridades a localização precisa do produto ou proveito do crime e dos bens que possam ter sido submetidos a esquemas de lavagens de capitais. $\mathrm{O}$ inciso IV descreve outro possível resultado da colaboração, o qual se encaixa com a modalidade ora demonstrada: "a recuperação total ou parcial do produto ou do proveito das infrações penais praticadas pela organização criminosa”.

Nesse desiderato, "produto" da infração (producta sceleris) é o produto imediato do delito. Os bens que efetivamente chegam ao controle do criminoso. Cite-se como exemplos o objeto roubado ou o dinheiro obtido com corrupção. "Proveito" da infração (fructus sceleris), por sua vez, vem a ser o ganho obtido pelo resultado da utilização econômica do produto oriundo do delito, como o dinheiro obtido com a venda do objeto roubado, por exemplo ${ }^{45}$.

Sobre esta recuperação de produtos ou proveitos das infrações, indagação relevante seria sobre qual a destinação tais recursos deveriam ter ${ }^{46}$. A decisão monocrática de 16 de junho de 2016 do Ministro Teori Zavascki, na Petição n 5.210 reconheceu a lacuna legislativa existente na Lei 12.850/13 sobre este aspecto, devendo ser aplicado, por analogia, dispositivo do Código Penal:

\footnotetext{
${ }^{44}$ Para Guilherme de Souza Nucci, flagrante diferido ou retardado "é a possibilidade que a polícia possui de retardar a realização da prisão em flagrante, para obter maiores dados e informações a respeito do funcionamento, componentes e atuação de uma organização criminosa". NUCCI, Guilherme de Souza. Código de Processo Penal Comentado. $5^{\text {a }}$ ed., São Paulo, 2006. p. 593.

45 LIMA, 2018, p. 803.

${ }^{46}$ VASCONCELLOS, 2018, p. 193.
} 
4. Embora a Lei 12.850/2013 estabeleça, como um dos resultados necessários da colaboração premiada, "a recuperação total ou parcial do produto ou do proveito das infrações penais praticadas pela organização criminosa" (art. $4^{\circ}$, IV), o diploma normativo deixou de prever a destinação específica desses ativos. A lacuna, conforme aponta o Procurador-Geral da República, pode ser preenchida pela aplicação, por analogia, dos dispositivos que tratam da destinação do produto do crime cuja perda foi decretada em decorrência de sentença penal condenatória.

O art. 91, II, b, do Código Penal estabelece, como um dos efeitos da condenação, "a perda em favor da União, ressalvado o direito do lesado ou de terceiro de boafé: [...] b) do produto do crime ou de qualquer bem ou valor que constitua proveito auferido pelo agente com a prática do fato criminoso". É certo que, como a Petrobras é o sujeito passivo dos crimes em tese perpetrados por Paulo Roberto Costa e pela suposta organização criminosa que integrava, o produto do crime repatriado deve ser direcionado à Sociedade de Economia Mista lesada, para a restituição dos prejuízos sofridos, uma vez que o dispositivo legal invocado (art. 91, II, b, do Código Penal), ao tratar da perda do produto do crime para a União, ressalva expressamente o direito do lesado.

Não se afigura razoável, portanto, limitar a restituição à Petrobras a $80 \%$ (oitenta por cento) dos ativos repatriados, direcionando o restante à União. $\mathrm{O}$ próprio Procurador-Geral da República sustenta, na petição que deu origem a este procedimento, que os prejuízos causados à Petrobras ultrapassariam "o montante de R \$ 1.600.000.000,00 (um bilhão e seiscentos milhões de reais)" (fl. 7). Por isso, e considerando que o patrimônio repatriado nestes autos amonta a $\mathrm{R} \$$ 79.000.000,00 (setenta e nove milhões de reais), não há justificativa legal para limitar a 80\% (oitenta por cento) desse valor a reparação devida à Petrobras ${ }^{47}$.

Destarte, foi negado o pedido do Ministério Público Federal, que, com base no art. $7^{\circ}, \S 1^{\circ}$ da Lei 9.613/9848 (Lei de Lavagem de Bens e Capitais) pretendia a destinação parcial de 20 por cento do valor "aos órgãos responsáveis pela negociação e pela homologação do acordo de colaboração premiada que permitiu tal repatriação". Ou seja, almejava o Procurador-Geral da República a destinação dos recursos ao próprio MPF e à Justiça Federal, o que ao final não foi acolhido, tendo sido destinado à Petrobras na sua integralidade.

\footnotetext{
${ }^{47}$ BRASIL. Supremo Tribunal Federal. Petição $n^{\circ}$ 5.210/DF. Decisão monocrática, Rel. Min. Teori Zavascki, julgado em 16 jun. 2016. Disponível em: https://www.conjur.com.br/dl/teorimpf.pdf. Acesso em: 11 set. 2019.

48 Reza o referido artigo que "a União e os Estados, no âmbito de suas competências, regulamentarão a forma de destinação dos bens, direitos e valores cuja perda houver sido declarada, assegurada, quanto aos processos de competência da Justiça Federal, a sua utilização pelos órgãos federais encarregados da prevenção, do combate, da ação penal e do julgamento dos crimes previstos nesta Lei, e, quanto aos processos de competência da Justiça Estadual, a preferência dos órgãos locais com idêntica função."
} 


\subsubsection{A Colaboração para Libertação}

A última variedade que pode-se identificar no sistema atual é a chamada colaboração para libertação. Nesta, o colaborador indica o local onde se encontra a vítima mantida refém ou sequestrada, de forma a facilitar e possibilitar sua libertação. Trata-se do possível resultado proveniente da colaboração que está no inciso $\mathrm{V}$ do mesmo artigo $4^{\circ}$ : "a localização de eventual vítima com a sua integridade física preservada".

É imprescindível a efetividade das informações prestadas pelo colaborador para que este receba os prêmios decorrentes do acordo de colaboração premiada, como será melhor analisado mais a frente. Neste caso em particular, a lei preocupou-se em deixar esse requisito bem visível, à medida que não basta somente a revelação do local no qual a vítima é mantida em cativeiro, mas também o resgate deve ser plenamente eficaz, estando a vítima com sua integridade física preservada.

Nesse sentido, caso as autoridades encontrem a vítima morta ou se por acaso esta tenha conseguido escapar, seja por ter fugido com seus próprios esforços ou resgatada por terceiros que não tenham relação com as informações dadas pelo colaborador, não deverá ser autorizada a concessão dos benefícios avençados no contrato, ainda que o agente colaborador tenha dado a localização correta imaginando que a vítima estivesse viva, ou ainda aprisionada.

É possível ainda traçar um paralelo com um dispositivo do Código Penal, adicionado pela Lei $n^{\circ} 9.269$ de 1996. O $\S 4^{\circ}$ do artigo 159 do Códex, o qual versa sobre o crime de extorsão mediante sequestro, já previa que "se o crime é cometido em concurso, o concorrente que o denunciar à autoridade, facilitando a libertação do sequestrado, terá sua pena reduzida de um a dois terços".

Verifica-se, contudo, que a Lei 12.850 é mais benéfica ao réu, pois além de conferir a possibilidade da redução da penal, o juiz, observado o caso, pode ainda conceder o perdão judicial. 


\subsection{Pressupostos e Requisitos para Celebração e Cumprimento do Acordo de Colaboração Premiada}

Conforme já exarado, para que a colaboração premiada seja efetiva e respeite os princípios constitucionais e diretrizes legais, é necessário que ela seja instituída da forma mais clara e detalhada possível, criando balizas bem delimitadas com o intuito de eliminar ao máximo as incertezas que possam surgir sobre a forma de aplicação do instituto na prática.

Nesse sentido, é fundamental a presença de certas premissas, a serem respeitadas durante todo o processo de formação do acordo. Isso nos permite então separar a análise substancial do termo em dois momentos: o primeiro, num momento anterior à produção do acordo em si, verificando os pressupostos de admissibilidade deste; e o segundo momento, após a elaboração do trato, recaindo o exame sobre os seus requisitos de validade.

Os pressupostos de admissibilidade servem, de certa forma, para limitar a aplicabilidade do instituto, uma vez que a sua generalização significaria na violação de certas diretrizes do processo penal. Assim, o acordo apenas pode ser proposto pelas autoridades competentes, se, no caso concreto, verificar-se presentes tais pressupostos.

Por sua vez, os requisitos de validade são aqueles que condicionam a plena legitimidade na implantação e execução do acordo. Devem ser bem observados pelo juiz na homologação de modo a assegurar que o termo final respeitou o trâmite adequado e mostra-se coerente com a finalidade da colaboração.

Analisaremos ambos, separadamente.

\subsubsection{Pressupostos de Admissibilidade}

O primeiro pressuposto, conforme já explicitado no início do presente trabalho, quando da conceituação do instituto, é justamente a confissão do colaborador. A doutrina majoritária, constituída por nomes 
como Michelle Barbosa de Brito, Gustavo Badaró, Pierpaolo Bottini, Walter Barbosa Bittar e demais prestigiados autores definem a confissão como condição para realização da colaboração premiada ${ }^{49}$. Traduzindo essa ideia, Luiz Flávio Gomes leciona:

Aquele que simplesmente aponta a responsabilidade penal de terceiros é um informante ou testemunha, mas não um investigado ou réu colaborador ${ }^{50}$.

\section{Do mesmo modo, Guilherme de Souza Nucci:}

Se se realiza o interrogatório de um corréu e este, além de admitir a prática do fato criminoso do qual está sendo acusado, vai além e envolve outra pessoa, atribuindo-lhe algum tipo de conduta criminosa, referente à mesma imputação, ocorre a delação. Note-se, pois, que ela somente tem valor caso o interrogado, além de atribuir a outrem a prática do crime, também se confesse a autoria. Se negar, imputando-a a terceiro, não se trata de delação, mas de mero testemunho ${ }^{51}$.

\section{Ainda nessa esteira, alguns precedentes do STJ corroboram o}

entendimento aqui adotado. O REsp $\mathrm{n}^{\mathrm{o}} 1.102 .736$, julgado pela $5^{\mathrm{a}}$ turma, decidiu:

O instituto da delação premiada incide quando o Réu, voluntariamente, colabora de maneira efetiva com a investigação e o processo criminal. Esse testemunho qualificado deve vir acompanhado da admissão de culpa e deve servir para a identificação dos demais coautores ou partícipes e na recuperação do produto do crime, o que não se verificou no caso dos autos ${ }^{52}$.

\footnotetext{
49 Nesse sentido: BRITO, Michelle B. Delação premiada e decisão penal: da eficiência à integridade. Belo Horizonte: D'Plácido, 2016. p. 55;

BADARÓ, Gustavo; BOTTINI, Pierpaolo. Lavagem de dinheiro. Aspectos penais e processuais penais. São Paulo: RT, 2013. p. 174;

BITTAR, Walter Barbosa. A delação premiada no Brasil. In: BITTAR, Walter Barbosa (Coord.) Delação premiada. Direito estrangeiro, doutrina e jurisprudência. Rio de Janeiro: Lumen Juris, 2011. p. 168-171.

${ }^{50}$ GOMES, Luiz Flávio; SILVA, Marcelo Rodrigues da. Organizações criminosas e técnicas especiais de investigação: questões controvertidas, aspectos teóricos e práticos e análise da Lei 12.850/2013. Salvador: JusPODIVM, 2015. p. 240.

${ }^{51}$ NUCCI, Guilherme de Souza. O valor da confissão como meio de prova no processo penal. São Paulo: RT, 1997. p. 213.

${ }^{52}$ BRASIL. Superior Tribunal de Justiça. Recurso Especial $n^{\circ} 1.102 .736 / S P$. $5^{\text {a }}$ Turma, Rel. Min. Laurita Vaz, julgado em 4 mar. 2010. Disponível em: https://stj.jusbrasil.com.br/jurisprudencia/19152204/recurso-especial-resp-1102736-sp-20080264316-6-stj. Acesso em: 13 set. 2019.
} 
De igual natureza, o Agravo Regimental no Agravo de Instrumento $\mathrm{n}^{\text {o }}$ 1.285.269 definiu: "o instituto da delação premiada consiste em ato do acusado que, admitindo a participação no delito, fornece às autoridades elementos capazes de facilitar a resolução do crime" 53 .

Outro aspecto importante a salientar é que o colaborador deve ter conexão com o delito que imputa, caso contrário implicará na mesma situação e deverá igualmente ser considerado mera testemunha. Segundo Frederico Valdez Pereira, se o acusado não tiver nenhuma relação com os fatos que delata, considera-se "mera comunicação de crime" 54 .

Isso não significa que o colaborador apenas pode informar acerca de crimes os quais é partícipe ou coautor. A Orientação Conjunta 1/2018 do MPF determinou que:

É também cabível a celebração de acordo de colaboração ainda que algum dos resultados previstos no art. $4^{\circ}$, I, II, III, IV e V, da Lei 12.850 advenha unicamente em relação a fato(s) diverso(s) daquele(s) para o(s) qual(is) o colaborador tenha concorrido ${ }^{55}$.

Neste cenário, em que a distinção se torna muito tênue, parece mais correto, com a finalidade de evitar desacertos, que o acordo defina em seus termos de forma precisa os fatos os quais o colaborador tenha participação (mesmo que indireta) ou que possua pelo menos uma conexão com estes, delimitando as obrigações assumidas, direitos garantidos e possíveis benefícios. Assim, os prêmios não devem depender da atuação do colaborador em auxiliar quanto a crimes diversos aos do seu processo, o

\footnotetext{
${ }^{53}$ BRASIL. Superior Tribunal de Justiça. Agravo Regimental no Agravo de Instrumento $n^{o}$ 1.285.269/MG, $6^{\text {a }}$ Turma, Rel. Min. Og Fernandes, julgado em 4 nov. 2010. Disponível em: https://stj.jusbrasil.com.br/jurisprudencia/17584427/agravo-regimental-no-agravo-de-instrumentoagrg-no-ag-1285269-mg-2010-0041883-6/inteiro-teor-17584428?ref=juris-tabs. Acesso em: 13 set. 2019.

${ }^{54}$ PEREIRA, Frederico Valdez. Delação Premiada. Legitimidade e Procedimento. $3^{\mathrm{a}}$ ed. Curitiba: Juruá, 2016. p. 167.

${ }^{55}$ MINISTÉRIO PÚBLICO FEDERAL. Orientação Conjunta $n^{\circ} 1 / 2018$. Dispõe sobre os acordos de colaboração premiada. $2^{\mathrm{a}}$ e $5^{\mathrm{a}}$ Câmaras de Coordenação e Revisão - Combate à Corrupção. Brasília, 23 de maio de 2018. Disponível em: http://www.mpf.mp.br/atuacaotematica/ccr5/orientacoes/orientacao-conjunta-no-1-2018.pdf. Acesso em: 13 set. 2019.
} 
que sem sobra de dúvida geraria danos ao colaborador. Sobre isso, os egrégios professores Canotilho e Nuno Brandão lecionam brilhantemente:

A colaboração premiada não só não pode ser pactuada fora de um processo, como não pode ter efeitos fora do seu processo, designadamente, em relação a crimes legalmente insusceptíveis de processamento conjunto com aqueles que já formam o objecto processual dos autos em que o acordo é celebrado ${ }^{56}$.

O segundo pressuposto é o da adequação da colaboração com o fim pretendido. Isso significa que o que se busca, ao realizar um acordo de colaboração, é uma efetiva contribuição para com a persecução penal. Sendo assim, cabe aos proponentes do acordo verificar se este é um meio eficaz, viável e confiável para atingir um benefício na persecução penal do caso concreto que se pretende resolver.

Explicando esse pressuposto, Borges de Mendonça leciona:

O membro do MP e o Delegado de Polícia devem verificar a adequação da colaboração àquele caso concreto, à luz da estratégia investigativa e da persecução penal, sem olvidar a própria repercussão social do fato criminoso e sua gravidade ${ }^{57}$.

Cabe mencionar também, acerca deste pressuposto, entendimento de parte da doutrina ${ }^{58}$ que diz não ser possível aferir com antecedência essa efetividade da colaboração premiada, desconsiderando-a como um pressuposto de admissibilidade.

Isto porque, no momento da negociação e celebração do acordo o que se deve sopesar é a potencialidade da colaboração, no sentido de verificar elementos indicadores da probabilidade de êxito e benefício à persecução; a efetividade concreta só será constatada no decorrer do processo, culminando na sentença que determinará o benefício conferido, a partir do grau de cooperação.

\footnotetext{
${ }^{56}$ CANOTILHO, J. J. Gomes; BRANDÃO, Nuno. Colaboração premiada: reflexões críticas sobre os acordos fundantes da Operação Lava Jato. Revista Brasileira de Ciências Criminais, São Paulo, v. 133, ano 25, julho de 2017. p. 155.

${ }^{57}$ MENDONÇA, 2013, p. 11.

58 Nesse sentido: SILVA, Eduardo Araújo da. Organizações Criminosas. Aspectos penais e processuais da lei n. 12.850/13. São Paulo: Atlas, 2014. p. 57-58.
} 
Ancorado nesse pressuposto, poder-se-á descartar eventuais acordos que não tragam resultados benéficos ao caso concreto, o que se revela de extrema importância nos dias atuais, em que os acordos de colaboração premiada têm sido altamente fomentados e se proliferado de uma forma no mínimo questionável.

Relacionado a isso, temos outro pressuposto, qual seja a necessidade da colaboração. Esse pressuposto determina que a colaboração como meio de obtenção de prova deve ser necessária no casso concreto. Isso se dá basicamente pela importante dimensão dos dois polos concatenados num acordo de colaboração premiada: o grau de eficiência em relação ao fim almejado, que é justamente o desbaratamento da organização criminosa, a benefício da coletividade; e o nível do direito fundamental a ser restringido, em detrimento do colaborador.

O pressuposto da necessidade basicamente estrutura-se em dois fatores atinentes à colaboração premiada: (i) sua indispensabilidade para a persecução penal, de forma que evite-se uma generalização da aplicação do instituto, o que seria prejudicial, devendo-se assumir portanto um caráter de subsidiariedade no sistema probatório ${ }^{59}$; e (ii) a complexidade da investigação do caso concreto, de modo que apenas é razoável conceber prêmios ao infrator uma vez que sua participação é imprescindível para que as autoridades possuam alguma possibilidade de sucesso na investigação.

Essa excepcionalidade do emprego da colaboração premiada é aclarada por Fábio Bechara: "a colaboração premiada deve ser empregada na ausência de outros meios legais menos restritivos" 60 . Podemos afirmar, então, que o Ministério Público apenas pode propor um acordo de colaboração premiada se este for motivado na indispensabilidade para a persecução penal, em razão da complexidade da investigação.

\footnotetext{
${ }^{59}$ AMODIO, Ennio. Processo penale, diritto europeo e common law. Dal rito inquisitorio al giusto processo. Milano: Giuffrè, 2003. p. 245.

${ }^{60}$ BECHARA, Fábio Ramazzini. Colaboração processual: legalidade e valor probatório. Boletim IBCCrim, São Paulo, ano 23, v. 269, 2015. p. 7.
} 


\subsubsection{Requisitos de Validade}

Logo de início, cumpre trazer o que provavelmente é o requisito mais importante no tocante à validade de um acordo de colaboração premiada. Trata-se da voluntariedade do colaborador, ponto que talvez cause as discussões de maior animosidade justamente por ser objeto de grande controvérsia em relação aos críticos do instituto.

Antes de adentrar no requisito em si, importante notar que essa voluntariedade deve ser precedida, por óbvio, pela constatação de capacidade do réu em estar em juízo, ou seja, sua imputabilidade e plena capacidade de discernimento sobre sua situação.

Para além disso, deve-se verificar a chamada liberdade de agir. Isso significa que o colaborador não pode ser vítima de coação, nem ser persuadido por promessa ilícita ou acerca de vantagens não estipuladas no acordo. Sobre o tema, Leonardo Dantas Costa afirma que o colaborador deve "querer declarar sua vontade" de colaborar. Isso quer dizer que a merda declaração do agente não implica na comprovação da voluntariedade; esta deve ser acompanhada de um plus, qual seja a vontade de manifestar esse desejo de cooperar ${ }^{61}$.

Neste momento, há de se abrir um parêntese trazendo à baila o debate sobre a necessidade da espontaneidade junto à voluntariedade impressas no acordo, e a diferenciação entre estas, algumas vezes tratadas como sinônimos.

Para Renato Brasileiro de Lima, "ato espontâneo é aquele cuja intenção de praticá-lo nasce exclusivamente da vontade do agente, sem qualquer interferência alheia" ${ }^{2}$. Já o ato voluntário "é aquele que nasce de

\footnotetext{
${ }^{61}$ COSTA, Leonardo Dantas. Delação premiada. A atuação do Estado e a relevância da voluntariedade do colaborador com a justiça. Curitiba: Juruá, 2017. p. 156.

${ }^{62}$ LIMA, 2018, p. 804.
} 
sua livre vontade [do colaborador], desprovido de qualquer constrangimento"63.

A doutrina brasileira vêm travando muitas discussões sobre este requisito em especial. Um dos pontos debatidos é a necessidade ou não, além da não-coação e manifestação própria (voluntariedade), que essa vontade decorra do próprio colaborador, independente da iniciativa do acusador (espontaneidade).

Esta dubiedade surge em razão de alguns dispositivos mais antigos, conforme vimos no início do presente trabalho, mencionarem a palavra "espontaneidade" como necessidade para celebração do acordo. Cite-se como exemplo, a Lei $\mathrm{n}^{\circ}$ 9.034/95 e a Lei $\mathrm{n}^{\circ}$ 9.613/98. De maneira oposta, demais legislações que versam sobre a colaboração, sobretudo as mais recentes, passaram a utilizar o termo "voluntariedade". Como exemplo, as Leis $\mathrm{n}^{\circ}$ 9.080/95, $\mathrm{n}^{\circ}$ 11.343/06, e por óbvio, a Lei $\mathrm{n}^{\circ}$ 12.850/13 (esta última inclusive revogando a Lei $\mathrm{n}^{\circ}$ 9.034/95).

O STJ, num primeiro momento, adotou a tese de que a espontaneidade seria requisito inequívoco à colaboração, conforme voto do Ministro relator Arnaldo Esteves Lima no REsp n⿳0 628.048, in verbis:

De fato, a Lei 9.034/95, que dispôs sobre os meios de prevenção e repressão de ações praticadas por organizações criminosas, previu a redução da pena de $1 / 3$ a $2 / 3$ para os que, espontaneamente, colaborarem no esclarecimento de infrações penais e sua autoria $\left(\right.$ art. $6^{\circ}$ ). Tal contribuição por parte do indiciado deverá ser espontânea, ou seja, de livre vontade, sem a instigação ou coação de terceiros. A revelação deve ser eficaz, ou seja, deve produzir efeitos práticos quanto aos demais integrantes da quadrilha, grupo, organização ou bando, ou na localização do produto, substância ou droga ilícita ${ }^{64}$.

Entretanto, devido ao sólido alicerce conferido ao regime, graças à boa redação da Lei $\mathrm{n}^{\circ} 12.850 / 13$, atualmente prevalece o entendimento de que o requisito para a validade do acordo de colaboração é a

\footnotetext{
${ }^{63}$ LIMA, 2018, p. 804.

${ }^{64}$ BRASIL. Superior Tribunal de Justiça. Recurso Especial $n^{\circ}$ 628.048/SP. $5^{\text {a }}$ Turma, Rel. Min. Arnaldo Esteves Lima, julgado em 24 mar. 2009. Disponível em:

https://ww2.stj.jus.br/processo/revista/inteiroteor/?num_registro $=200400118156 \& d t \_p u b l i c a c a 0=1$ 3/04/2009. Acesso em: 21 out. 2019.
} 
voluntariedade, e não a espontaneidade ${ }^{65}$, podendo a proposta e o princípio das negociações surgirem por parte do acusador ${ }^{66}$.

Amparado a isso, temos a decisão do STF no HC 129.877, no qual o relator Ministro Marco Aurélio considerou ambos os vocábulos como sinônimos, o que gerou divergência entre os demais ministros. O Ministro Luis Fux, após vista dos autos, proferiu o seguinte voto, destacando a distinguibilidade dos conceitos, bem como a necessidade da voluntariedade, mas não da espontaneidade, para a validade e pela efetividade do acordo:

De toda sorte, como já sublinhado anteriormente, embora a Lei 9.613/98 estabelecesse a necessidade da espontaneidade da colaboração premiada, a partir da Lei 9.807/99 (em jogo no presente caso), deixou-se de exigir a espontaneidade da colaboração, passando-se à previsão de que a voluntariedade do ato, somada à efetividade da colaboração, são suficientes para a concessão dos benefícios ao réu colaborador. É esta, também, a previsão da Lei 12.850/2013.

In casu, o eminente Relator entendeu, em seu voto, que a sentença e o acórdão condenatórios, ao empregarem o conceito de 'espontaneidade', utilizaram-no como mero sinônimo de 'voluntariedade', e não no sentido que lhe é atribuído juridicamente, a acrescentar, ao caráter voluntário do ato, as características da ausência de fatores externos motivadores e da iniciativa do agente.

$(\ldots)$

À luz das premissas teóricas lançadas no presente voto, entendo importante deixar assentado que os conceitos jurídicos de 'voluntariedade' e 'espontaneidade' vêm sendo diferenciados, pela doutrina e pela jurisprudência, de modo que a voluntariedade implica, unicamente, a ausência de coação, o ato praticado livre de qualquer constrangimento. Já a espontaneidade exige, em regra, além da voluntariedade, também 'a livre disposição do agente de procurar a autoridade para, evidenciando alto grau de responsabilidade moral, informar a prática da infração penal ignorada ou imputada a outrem'.

\footnotetext{
${ }^{65}$ Nesse sentido: SUXBERGER, Antonio H. G.; MELLO, Gabriela S. J. V. A voluntariedade da colaboração premiada e sua relação com a prisão processual do colaborador. Revista Brasileira de Direito Processual Penal, v. 3, n. 1. Porto Alegre, Jan./Abr. 2017. p. 204;

AIRES, Murilo T.; FERNANDES, Fernando A. A colaboração premiada como instrumento de política criminal: a tensão em relação às garantias fundamentais do réu colaborador. Revista Brasileira de Direito Processual Penal, v. 3, n. 1. Porto Alegre, Jan./Abr. 2017, p. 266;

LEMOS, Bruno E.; QUINTIERE, Victor M. Técnicas especiais de investigação no processo penal. Belo Horizonte: D'Plácido, 2017. p. 35;

LIMA, 2018, p. 804.

${ }^{66}$ VASCONCELLOS, 2018, p. 151
} 
In casu, a leitura da sentença condenatória conduz à conclusão de que foi exigida a espontaneidade, e não apenas a voluntariedade da colaboração, especialmente em razão dos seguintes trechos: 'Entretanto, considero que a conduta da ré não resultou de espontaneidade. [...] Em verdade, a ré apenas colaborou com a atuação policial porque sentiu-se intimidada com a situação vivenciada'.

Cuida-se de fatores absolutamente irrelevantes para a análise do cabimento do perdão judicial, uma vez que o art. 13 da Lei 9.870/99 não exige a espontaneidade, mas tão somente a voluntariedade. Portanto, se a colaboração foi um ato de vontade da paciente, não há de se perquirir os motivos que a conduziram a praticá-lo ${ }^{67}$. (grifos originais).

Destarte, resta claro que conforme o entendimento mais atual, esposado na cristalina decisão acima colacionada, a lei não exige espontaneidade, sendo irrelevante uma análise quanto à motivação interna do agente colaborador, se esta resultou de legítimo arrependimento, mero temor, puro interesse na obtenção de vantagens ou qualquer outro motivo; até mesmo porque (i) tal exame não encontra amparo legal; (ii) seria impossível apurar as verdadeiras razões que conduziram o acusado a celebrar o acordo; e (iii) a preocupação do Direito está em buscar o resultado benéfico da colaboração e não com os motivos internos que transformaram o sujeito num colaborador.

Isto posto, desde que não haja coação, é tranquilamente possível que o acusado tenha sido aconselhado ou até mesmo incentivado por terceiro (inclusive pelas autoridades) a realizar a colaboração premiada, eis que não se vislumbra vício nessa hipótese ${ }^{68}$.

Em seguida, temos outro requisito que se correlaciona com a voluntariedade. Segundo Leonardo Dantas Costa e Vinicius Gomes de Vasconcellos, é o chamado requisito da inteligência/informação. Tal requisito imprime a ideia de que o colaborador deve ter pleno conhecimento e compreensão da sua situação fática, sobre a acusação que lhe é imputada,

\footnotetext{
${ }^{67}$ BRASIL. Supremo Tribunal Federal. Habeas Corpus $n^{\circ}$ 129.877/RJ. $1^{\text {a }}$ Turma, Rel. Min. Marco Aurélio, julgado em 18/04/2017. Disponível em:

http://portal.stf.jus.br/processos/downloadPeca.asp?id=312161444\&ext=.pdf. Acesso em: 22 out. 2019.

${ }^{68}$ Nesse sentido: SUXBERGER; MELLO, 2017;

LIMA, 2018, p. 804.
} 
seus direitos e garantias que devem estar presentes no acordo, bem como as possíveis renúncias (admitidas) à estes que poderá ter que vir a fazer.

Em relação à acusação, o imputado deve conhecer as alegações, a maneira que deve ser provada a sua participação nos eventuais delitos, e que elementos probatórios já estão em posse das autoridades, possibilitando desta forma um vislumbre sobre suas reais possibilidades. Nas palavras de Mariana Lauand, "deverão, imputado colaborador e seu advogado, outrossim, ter ciência do inteiro teor dos autos antes de decidirem realizar a colaboração processual" ${ }^{\prime 69}$.

No que tange ao acordo em si, deve ser claro as consequências deste, ou seja, as obrigações que o colaborador assumirá e seus possíveis benefícios, os reflexos de uma eventual condenação (por exemplo os efeitos gerados em esfera cível e administrativa), bem como a abrangência do acordo de colaboração, outras possíveis sanções aplicadas, etc.

Finalmente, tratando-se dos direitos, o agente colaborador deve ter ciência de certas renúncias que deverá realizar, como por óbvio o direito ao silêncio, sem prejuízo de demais termos previstos no acordo. Na lição de Frederico Valdez Pereira, sobre este exemplo, deve-se "alertar o agente de seu direito constitucional ao silêncio e de que a opção pela colaboração vai importar em renúncia a esse direito no caso concreto" 70 .

O Manual da Colaboração Premiada, lançado por iniciativa da Estratégia Nacional de Combate à Corrupção e à Lavagem de Dinheiro (ENCCLA) - por sua vez criado no âmbito do MPF em 2003 - prevê o chamado "dever de esclarecimento ao colaborador", no qual "as autoridades responsáveis pela investigação devem informar ao colaborador, na presença de seu defensor: (a) o seu direito constitucional ao silêncio; (b) a colaboração implicará renúncia a esse direito e compromisso legal de dizer

\footnotetext{
${ }^{69}$ LAUAND, Mariana de Souza Lima. O valor probatório da colaboração processual. Dissertação (Mestrado em Direito). Faculdade de Direito, Universidade de São Paulo, São Paulo, 2008. p. 114. ${ }^{70}$ PEREIRA, 2016, p. 131.
} 
a verdade; (c) os benefícios previstos em lei; (d) as informações devem ser completas, verdadeiras e úteis, do contrário, não terá direito ao benefício"71.

Resumidamente, em termos práticos, este requisito consiste em deixar claro ao colaborador que a formalização e a homologação garantem maior segurança e previsibilidade ao acordo, no entanto, os benefícios estão adstritos à real efetividade daquela cooperação; isto é, os prêmios não vêm garantidos de forma automática com a simples celebração do acordo de colaboração.

Em seguida, temos a necessidade da assistência de um defensor técnico ao colaborador, de caráter indispensável e irrenunciável. A legislação atual andou no sentido de garantir esse direito ao colaborador de uma maneira afincada.

Surge como instrumento para assegurar os requisitos anteriormente citados, posto que a presença do defensor público ou advogado (podendo ser indicado pelo colaborador) visa assegurar justamente a voluntariedade e a inteligência/informação do consentimento do acusado, afastando acordos desleais, injustos, excessivamente onerosos, prejudiciais ao imputado ou realizados sob coação.

Analisando-se a lei, podemos citar o art. $4^{\circ}, \S 15$ da Lei do Crime Organizado, que assevera que "em todos os atos de negociação, confirmação e execução da colaboração, o colaborador deverá estar assistido por defensor". No mesmo sentido, a Orientação Conjunta 1/2018 do MPF dispõe: "nenhuma tratativa sobre colaboração premiada deve ser realizada sem a presença do advogado constituído ou Defensor Público"72.

Saliente-se que a presença, acompanhamento, consulta e aconselhamento do defensor são de fundamental importância para a proteção do colaborador, mas por si só não geram presunção de legalidade e

\footnotetext{
${ }^{71}$ Disponível em: http://www.mpf.mp.br/atuacao-tematica/sci/dados-da-atuacao/eventos2/eventos-internacionais/conteudo-banners-1/enccla/restrito/manual-colaboracao-premiadajan14.pdf/view. Acesso em: 30 out. 2019.

${ }_{72}$ MINISTÉRIO PÚBLICO FEDERAL. Orientação Conjunta no 1/2018. Acesso em: 13 set. 2019.
} 
veracidade ou efetividade das alegações feitas no âmbito da colaboração premiada.

Por último, mas não menos importante, o requisito da corroboração externa. Este requisito é de larga relevância na dinâmica do sistema de colaboração premiada, haja vista que não basta que o colaborador apenas relate e/ou divulgue as informações, mas confirme-as com elementos externos.

Este requisito possui uma dupla função, que é a chancela dos elementos trazidos como forma de cooperação na persecução, sendo de interesse do acusador; mas também a garantia dos direitos fundamentais do acusado, pois, nos termos do artigo $4^{\circ}, \S 16$ da Lei 12.850/13, "nenhuma sentença condenatória será proferida com fundamento apenas nas declarações de agente colaborador". Essa concepção decorre da própria natureza da colaboração premiada, que conforme já averiguamos ${ }^{73}$, é de meio de obtenção de prova, e não de prova em si, de modo que a sentença não pode apenas se embasar no teor da colaboração.

A supradita Orientação Conjunta $1 / 2018$ do MPF também tratou do tema:

Desde o início das tratativas, o membro do Ministério Público Federal deve se preocupar em analisar se os fatos apresentados pelo colaborador estão suficientemente corroborados por outros elementos probatórios, inclusive externos e em poder de terceiros, ou se serão passíveis de corroboração, tendo em vista as técnicas de investigação normalmente desenvolvidas, observando-se o disposto no art. $4^{\circ}, \S 16$, da Lei 12.850/2013 ${ }^{74}$.

\subsection{Legitimidade para propor o Acordo de Colaboração Premiada}

A Lei $12.850 / 13$ trouxe, em seu art. $4^{\circ}, \S 6^{\circ}$, a seguinte redação, que determina a legitimidade do proponente dos acordos de colaboração premiada:

\footnotetext{
${ }^{73}$ Ver item 1.1.

${ }^{74}$ MINISTÉRIO PÚBLICO FEDERAL. Orientação Conjunta $n^{\circ}$ 1/2018. Acesso em: 13 set. 2019.
} 
O juiz não participará das negociações realizadas entre as partes para a formalização do acordo de colaboração, que ocorrerá entre o delegado de polícia, o investigado e o defensor, com a manifestação do Ministério Público, ou, conforme o caso, entre o Ministério Público e o investigado ou acusado e seu defensor ${ }^{75}$.

Um pouco antes, no $\S 2^{\circ}$ do mesmo dispositivo, tal é a redação referente à legitimidade para requerer ao magistrado a concessão do perdão judicial que não houver sido requerida a princípio:

Considerando a relevância da colaboração prestada, o Ministério Público, a qualquer tempo, e o delegado de polícia, nos autos do inquérito policial, com a manifestação do Ministério Público, poderão requerer ou representar ao juiz pela concessão de perdão judicial ao colaborador, ainda que esse benefício não tenha sido previsto na proposta inicial, aplicando-se, no que couber, o art. 28 do Decreto-Lei n ${ }^{\circ} 3.689$, de 3 de outubro de 1941 (Código de Processo Penal) ${ }^{76}$.

Tais dispositivos, quando da edição da lei, passaram a ideia de que a legitimidade para propor os acordos de colaboração seria concorrente entre o Ministério Público e os delegados de polícia. Essa excentricidade trazida pela legislação causou estranheza, e, logo em seguida à sua entrada em vigor, diversos doutrinadores criticaram, de forma lúcida e apropriada, o teor de tais artigos, assentando seu desalinho com a Constituição, uma vez que apenas o Ministério Público poderia negociar e/ou propor acordos no âmbito da persecução penal ${ }^{77}$.

Nesse ponto de vista, ensina Renato Brasileiro de Lima:

\footnotetext{
75 BRASIL. Lei $n^{\circ} 12.850$ de 02 de agosto de 2013. Dispõe sobre a prevenção, o tratamento, a fiscalização, o controle e a repressão à produção, ao uso e ao tráfico ilícitos de produtos, substâncias ou drogas ilícitas que causem dependência física ou psíquica, assim elencados pelo Ministério da Saúde, e dá outras providências. Brasília, DF, 02 ago. 2013.

${ }^{76}$ Ibid., Brasília, DF, 02 ago. 2013.

${ }^{77}$ Nesse sentido: MENDONÇA, 2013, p. 14;

BITENCOURT, Cezar Roberto; BUSATO, Paulo Cesar. Comentários à Lei de Organização Criminosa: Lei n.12.850/2013. São Paulo: Saraiva, 2014. p. 122-124;

FILIPPETTO, Rogério; ROCHA, Luísa C. V. C. Colaboração premiada: contornos segundo o sistema acusatório. Belo Horizonte: D'Plácido, 2017. p. 146-154;

PACELLI, Eugênio. Curso de Processo Penal. 20a ed., São Paulo: Atlas, 2016. p. 856-858;

DEMERCIAN, Pedro H. A colaboração premiada e a lei das organizações criminosas. Revista jurídica ESMP-SP, v. 9, n 1, Jan./Jun. 2016. p. 75-76;

ROMERO, Eneas. A colaboração premiada. In: AMBOS, Kai; ROMERO, Eneas (Coord.). Crime organizado. Análise da Lei 12.850/2013. São Paulo: Marcial Pons, 2017. p. 267;

FONSECA, Cibele B. G. Colaboração premiada. Belo Horizonte: Del Rey, 2017. p. 118; LIMA, 2018, p. 818.
} 
No entanto, por mais que a autoridade policial possa sugerir ao investigado a possibilidade de celebração do acordo de colaboração premiada, daí não se pode concluir que o Delegado de Polícia tenha legitimação ativa para firmar tais acordos com uma simples manifestação do Ministério Público. Por mais que a Lei $\mathrm{n}^{\circ}$ 12.850/13 faça referência à manifestação do Ministério Público nas hipóteses em que o acordo de colaboração premiada for "firmado pelo Delegado de Polícia", esta simples manifestação não tem o condão de validar o acordo celebrado exclusivamente pela autoridade policial. Isso porque a Lei $\mathrm{n}^{\circ} 12.850 / 13$ não define bem o que seria essa manifestação, que, amanhã, poderia ser interpretada como um simples parecer ministerial, dando ensejo, assim, à celebração de um acordo de colaboração premiada pela autoridade policial ainda que o órgão ministerial discordasse dos termos pactuados ${ }^{78}$.

\title{
No mesmo sentido, cabe também trazer a lição do professor Eugênio
}

Pacelli de Oliveira, quando do advento da lei em comento, aprofundando a discussão na seara processual:

\begin{abstract}
Se o sistema processual penal brasileiro sequer admite que a autoridade policial determine o arquivamento de inquérito policial, como seria possível admitir, agora, a capacidade de atuação da referida autoridade para o fim de: a) extinguir a persecução penal em relação a determinado agente, sem a consequente legitimação para promover a responsabilidade penal dos demais (delatados), na medida em que cabe apenas ao Parquet o oferecimento da denúncia; b) viabilizar a imposição de pena a determinado agente, reduzida ou com a substituição por restritiva de direito, condicionando previamente a sentença judicial; c) promover a extinção da punibilidade do fato, em relação a apenas um de seus autores ou partícipes, nos casos de perdão judicial.
\end{abstract}

\section{$(\ldots)$}

Por todas essas considerações, não nos parece aceitável a possibilidade de propositura e de formalização de acordo de colaboração pelo delegado de polícia, não se podendo aceitar, então, que o juiz decida por homologação um ajuste com tais características.

Ou bem se admite a inconstitucionalidade de tais normas, ou, se for possível aceitar a validade da atuação policial na colaboração premiada, que esteja ela condicionada à manifestação favorável do Ministério Público, caso em que o acordo, naturalmente, teria como parte legítima o Parquet e não o delegado de polícia $^{79}$.

\footnotetext{
${ }^{78}$ LIMA, 2018, p. 818.

79 OLIVEIRA, Eugênio Pacelli de. Atualização da $17^{a}$ edição do curso de processo penal em virtude da Lei $n^{\circ}$ 12.850/13. Disponível em:

http://www.criminal.mppr.mp.br/arquivos/File/ANEXOS/INF_264_Organizacoes_criminosas_pac elli.pdf. Acesso em: 25 out. 2019.
} 
Além do posicionamento acima exarado, que parece o mais correto, a irresolução gerou as mais variadas interpretações. Sob outra ótica, há ainda entendimento de parte da doutrina ${ }^{80}$ de que a Lei 12.850/13 em momento algum concedeu legitimidade aos delegados de polícia para elaborarem os acordos de colaboração premiada. Isso porque, segundo essa corrente, o texto seria claro em condicionar a atuação policial à manifestação do Ministério Público. Frederico Valdez Pereira afirma que:

Na prática, a autoridade policial somente poderá iniciar as tratativas direcionadas a verificar o interesse na colaboração, e, em seguida, representar ao membro do MP para que conduza a formalização do acordo e encaminhe a postulação ${ }^{81}$.

Para Flávio Cruz, “o Ministério Público - o dominus litis (art. 129, I, CF) - não fica vinculado às representações e deliberações das autoridades policiais" $"$.

Por outro lado, há corrente que sustenta a legitimidade dos delegados de polícia para propor o $\operatorname{acordo}^{83}$. De maneira mais moderada, intermediária, haveria a possibilidade dos delegados tomarem a iniciativa para propor acordos de colaboração que prevejam alguns benefícios que não dependem do posicionamento do Ministério Público (como por exemplo medidas de proteção ao delator previstas em legislação

\footnotetext{
${ }^{80}$ Nesse sentido: MENDRONI, Marcelo Batlouni. Comentários alei de Combate ao Crime Organizado: Lei n. 12.850/13. São Paulo: Atlas, 2014. p. 44;

ESSADO, Tiago C. Delação premiada e idoneidade probatória. Revista Brasileira de Ciências Criminais, São Paulo, ano 21, v. 101, 2013. p. 213;

DIDIER JÚNIOR, Freddie; BOMFIM, Daniela. Colaboração premiada (Lei n. 12.850/2013): natureza jurídica e controle da validade por demanda autônoma - um diálogo com o Direito Processual Civil. Civil Procedure Review, v. 7, n. 2, Mai./Ago. 2016. p. 147;

BEZERRA, Edson A.; MELLO, Luis Fernando. Colaboração premiada: um instituto questionável para a produção de provas. Iurisprudentia, Juína, a. 5, n. 9, p. 9-42, Jan./Jun. 2016. p. 22.

${ }^{81}$ PEREIRA, 2016, p. 132.

${ }^{82}$ CRUZ, Flávio A. Plea bargaining e delação premiada: algumas perplexidades. Revista jurídica da Escola Superior de Advocacia da OAB-PR, Curitiba, v. 1, n. 2, Dez. 2016. p. 193.

83 Nesse sentido: SANTOS, Marcos Paulo Dutra. Colaboração unilateral premiada como consectário lógico das balizas constitucionais do devido processo legal brasileiro. Revista Brasileira de Direito Processual Penal. Porto Alegre, v. 3, n 1, Jan./Abr. 2017. p. 159-160; COSTA, 2017, p. 117;

ANSELMO, Márcio A. Colaboração premiada. O novo paradigma do processo penal brasileiro. Doutrina e prática. A visão do delegado de polícia. Rio de Janeiro: Mallet, 2016. p. 84.
} 
específica $)^{84}$. Há ainda posição que, em eventual situação de ilegítima negativa do Ministério Público em proceder com o acordo de colaboração, excepcionalmente a proposição poder-se-ia ser feita pelo delegado de polícia ${ }^{85}$. Este último entendimento parece incorreto, adotando a doutrina de Andrey Borges de Mendonça, pois nesse caso a melhor solução seria a remessa ao PGJ, aplicando-se por analogia o art. 28 do $\mathrm{CPP}^{86}$, inclusive mencionado como diretriz no próprio art. $4^{\circ}, \S 2^{\circ}$ da Lei $12.850 / 13$.

De maneira expectável, em abril de 2016 o então Procurador-Geral da República Rodrigo Janot ajuizou Ação Direta de Inconstitucionalidade em face de ambos os dispositivos supracitados, que será objeto do próximo item.

\subsubsection{A Decisão do Supremo Tribunal Federal na ADI 5508 - Possibilidade de Acordos de Colaboração Premiada Firmados por Delegados de Polícia}

A Ação Constitucional proposta pela Procuradoria-Geral da República combatia os trechos da lei que conferem legitimidade aos delegados poder para realizar os acordos de colaboração, uma vez que estes violariam princípios-base do ordenamento brasileiro, mesmo com a manifestação do MP assegurada nos mesmos parágrafos impugnados.

Em apertada síntese, foi alegado que os dispositivos atacados:

Contrariam o devido processo legal (Constituição da República, art. 5, LIV), o princípio da moralidade (art. 37, caput), o princípio acusatório, a titularidade da ação penal pública conferida ao Ministério Público pela Constituição (art. 129, I), a exclusividade do exercício de funções do Ministério Público por membros legalmente investidos na carreira (art. 129, § $2^{\circ}$, primeira parte) e a função

\footnotetext{
84 CAVALI, Marcelo Costenaro. Duas faces da colaboração premiada: visões "conservadora" e "arrojada" do instituto na Lei 12.850/2013. In: MOURA, Mara Thereza A.; BOTTINI, Pierpaolo C. (Coord.). Colaboração premiada. São Paulo: RT, 2017. p. 269-270.

${ }^{85}$ Ibid., p. 85.

${ }^{86}$ MENDONÇA, 2013, p. 14.
} 
constitucional da polícia, como órgão de segurança pública (art. 144, especialmente os $\S \S 1^{\circ}$ e $\left.4^{\circ}\right)^{87}$.

Ainda que, em linhas gerais, o Brasil não tenha formalmente adotado o princípio acusatório puro, é inegável a presença de várias de suas características na tônica do processo penal aqui praticado, asseguradas pela Constituição, que assim o fez visando afastar uma contaminação dos processos por aspectos que seriam inerentes ao sistema inquisitivo.

O Poder Constituinte imprimiu essa ideia no citado art. 129, I, da Constituição de 1988, o qual conferiu, privativamente, a função de promoção da ação penal pública ao Ministério Público. Assim, não se pode conferir legitimidade aos delegados de polícia, o que implicaria em afastar o protagonismo das partes (acusação e defesa).

Princípio basilar do Direito, a interpretação das leis conforme a Constituição integra a Hermenêutica Constitucional e encaixa-se perfeitamente no caso em comento. Significa que as leis infraconstitucionais devem ser interpretadas à luz do texto Constitucional, e não o inverso (gesetzeskonform Verfassungsinterpretation $)^{88}$.

Admitindo uma proposta de um sujeito que não é parte da relação processual, a lei faz aflorar papel inquisitorial do julgador, pois sua imparcialidade e inércia ficam prejudicadas, colocando o próprio devido processo legal em xeque. Para além disso, o direito de defesa também é ferido, uma vez que o juiz verificará proposta resultante de negociação feita sem a provocação do titular da ação penal; ou pior, contra a vontade deste ${ }^{89}$.

\footnotetext{
87 PGR, Petição inicial da Ação Direta de Inconstitucionalidade $n^{\circ}$ 5.508, Supremo Tribunal Federal. Disponível em: http://www.mpf.mp.br/pgr/documentos/adi-5508. Acesso em: 25 out. 2019.

${ }^{88}$ CANOTILHO, José Joaquim Gomes. Direito Constitucional e teoria da constituição. $2^{\mathrm{a}}$ ed., Coimbra: Almedina, 1998. p. 1.106;

Walter Leisner, autor da ideia, indica o risco da "interpretação da Constituição segundo a lei", dando à Constituição um caráter muito aberto, preenchido por leis ordinárias, levando-se ao paradoxo de interpretações constitucionais inconstitucionais. LEISNER, Walter. Die Gesetzmäßigkeit der Verfassung. Schriften zu Staatslehre und Staatsrecht 1957-1991. Berlin: Duncker \& Humblot, 1994. p. 276-289.

${ }^{89}$ LEISNER, 1994, p. 276-289.
} 
Contudo, apesar de vasta argumentação lastreada pelos princípios constitucionais, e de igual forma, respaldada por inúmeros doutrinadores, como se tentou mostrar aqui, o Supremo Tribunal Federal, de maneira infeliz, julgou improcedente a ação, entendendo pela possibilidade de delegados de polícia firmarem acordos de colaboração premiada. Nos termos do voto do relator Ministro Marco Aurélio:

(...) Os preceitos asseguram ao delegado de polícia a legitimidade para a proposição do acordo de colaboração premiada - instrumento de obtenção de prova - na fase de investigação, quando desenvolvida no âmbito do inquérito policial. Sendo a investigação o principal alvo da polícia judiciária, ante a conformação constitucional conferida pelo artigo 144, meios previstos na legislação encontram-se inseridos nas prerrogativas da autoridade policial. Sendo a polícia a única instituição que tem como função principal o dever de investigar, surge paradoxal promover restrição das atribuições previstas em lei. Retirar a possibilidade de utilizar, de forma oportuna e célere, o meio de obtenção de prova denominado colaboração premiada é, na verdade, enfraquecer o sistema de persecução criminal, inobservando-se o princípio da vedação de proteção insuficiente. (...)

Não se trata de questão afeta ao modelo acusatório, deixando de caracterizar ofensa ao artigo 129, inciso I, da Constituição Federal, estando relacionada, tão somente, ao direito de punir do Estado, que se manifesta por intermédio do Poder Judiciário. (...)

Os textos impugnados versam regras claras sobre a legitimidade do delegado de polícia na realização de acordos de colaboração premiada, estabelecendo a fase de investigações, no curso do inquérito policial, como sendo o momento em que é possível a utilização do instrumento pela autoridade policial. Há previsão específica da manifestação do Ministério Público em todos os acordos entabulados no âmbito da polícia judiciária, garantindo-se, com isso, o devido controle externo da atividade policial já ocorrida e, se for o caso, adoção de providência e objeções. As normas legais encontram-se em conformidade com as disposições constitucionais alusivas às polícias judiciárias e, especialmente, às atribuições conferidas aos delegados de polícia. Interpretação que vise concentrar poder no Órgão acusador desvirtua a própria razão de ser da Lei $\mathrm{n}^{\circ} 12.850 / 2013$, na qual presente que todas as autoridades envolvidas - delegado de polícia, membro do Ministério Público e juiz -, como agentes essenciais à consecução da Justiça criminal, possam realizar, cada qual no exercício legítimo das próprias funções, as atividades que lhes são constitucionalmente atribuídas. (...)

Ante o quadro, julgo improcedente o pedido, assentando a constitucionalidade dos parágrafos $2^{\circ}$ e $6^{\circ}$ do artigo $4^{\circ}$ da Lei $n^{\circ} 12.850 / 2013^{90}$.

\footnotetext{
${ }^{90}$ STF, Ação Direta de Inconstitucionalidade $n^{o} 5.508$. Voto Min. Rel. Marco Aurélio. Disponível
} 
Conforme o entendimento já consignado no decorrer deste trabalho, aparenta inadequado tal percepção da Corte, seja pela violação da atribuição privativa do Ministério Público para promover a ação penal (art. 129, I, $\mathrm{CF}$ ), seja pela vedação de um juiz com atributos inquisitivos - conforme já declarado pelo próprio STF na ADI $\mathrm{n}^{\mathrm{o}} 1.570^{91}$ - mas, sobretudo, pela flagrante usurpação dos poderes próprios dos integrantes do Ministério Público pelos delegados de polícia, ao negociarem e conduzirem acordos de colaboração premiada.

Não se pretende, em nenhum momento, desqualificar e excluir os integrantes das organizações policiais num sistema penal complexo como temos, ou mesmo negar sua importância. O cerne da questão é a vontade do Constituinte, que não pode ser mascarada pela legalidade conferida a dispositivos nefastos como estes contestados, ora chancelados, pela Corte. Corte essa, que deveria como incumbência principal, zelar pela Constituição; obstando normas que, porventura venham a chocar-se com os propósitos entalhados pela Assembleia de 1987-1988. Mais uma vez, brilhantemente, Eugênio Pacelli nos ensina:

(...) a função de titularidade da ação penal pública é privativa do Ministério Público. E não porque queiramos, mas por expressa determinação constitucional (art. 129, I, CF). E por ação penal há que se entender a iniciativa da persecução penal em juízo. Nesse contexto, tanto o oferecimento de denúncia quanto o requerimento de arquivamento do inquérito policial constituem regular exercício da titularidade da ação penal e, de modo mais amplo, da persecução penal em juízo. Também outras providências não relacionadas diretamente com a acusação em juízo são privativas do Ministério Público, precisamente por se inserirem no contexto da respectiva modalidade de persecução penal, tal como ocorre em relação à titularidade para a proposta de suspensão condicional do processo (art. 89, Lei 9.099/95) e [a] transação penal (art. 76, Lei 9.099/95). E nem poderia ser de outro modo, na medida em que a única instituição pública no Brasil com

em: http://www.stf.jus.br/arquivo/cms/noticiaNoticiaStf/anexo/ADI5508MMA.pdf. Acesso em: 25 out. 2019.

91 BRASIL. Lei 9034/95. Lei Complementar 105/01. Superveniente. Hierarquia superior. Revogação implícita. Ação prejudicada, em parte. "Juiz de Instrução". Realização de diligências pessoalmente. Competência para investigar. Inobservância do devido processo legal. Imparcialidade do magistrado. Ofensa. Funções de investigar e inquirir. Mitigação das atribuições do Ministério Público e das Polícias Federal e Civil. Disponível em: http://stf.jus.br/portal/jurisprudencia/listarJurisprudencia.asp?s1=\%28ADI\%24\%2ESCLA\%2E+E $+1570 \% 2 \mathrm{ENUME} \% 2 \mathrm{E} \% 29+\mathrm{OU}+28 \mathrm{ADI} \% 2 \mathrm{EACMS} \% 2 \mathrm{E}+\mathrm{ADJ} 2+1570 \% 2 \mathrm{EACMS} \% 2 \mathrm{E} \% 29 \& \mathrm{~b}$ ase=baseAcordaos\&url=http://tinyurl.com/c5jws8j. Acesso em: 18 nov. 2019. 
legitimidade ativa para a persecução penal em juízo é o Ministério Público. No que toca às ações penais públicas, evidentemente. (...)

Eis então que se chega ao art. $4^{\circ}, \S 2^{\circ}$ e $\S 4^{\circ}$, da Lei $12.850 / 13$, que elege o Delegado de Polícia como autoridade com capacidade postulatória e com legitimação ativa para firmar acordos de colaboração, a serem homologados por sentença pelo juiz. Nada temos e nada poderíamos ter (quem sabe apenas em um passado longínquo e sombrio...) contra a autoridade e contra a importância do Delegado de Polícia na estrutura da investigação. (...) Todavia, o que a citada legislação pretende fazer é de manifesta e evidente inconstitucionalidade. E isso por uma razão muito simples: a Constituição da República comete à polícia, inquinada de judiciária, funções exclusivamente investigatórias (art. 144, $\S 1^{\circ}$, IV, e $\left.\S 4^{\circ}\right)$. E, mais, remete e comete ao Ministério Público a defesa da ordem jurídica (art. 127) e a promoção privativa da ação penal (art. 129, I ${ }^{92}$.

Nessa toada, a polícia tem o dever de atuar para o processo, e não no processo $^{93}$, o que resultaria num apoderamento indevido das funções exclusivas dos membros do Ministério Público, ferindo de igual forma o $\S$ $2^{\circ}$ do mesmo artigo 129 da Constituição.

Isso ainda é agravado à medida que, tratando-se de instituto que tem um potencial despenalizador, apenas o Ministério Público tem legitimidade para transigir, já que estaríamos na prática diante de uma forma de mitigação do princípio da obrigatoriedade da ação penal, que será tema de estudo num próximo tópico. Nas palavras do ilustre professor Mirabete:

O Ministério Público é o titular, privativo, da ação penal pública, afastada a possibilidade de iniciativa e, portanto, de disponibilidade por parte do juiz (art. 129, I, da Constituição Federal). Não podendo, portanto, a lei, e muito menos uma interpretação extensiva dela, retirar-lhe o direito de pedir a prestação jurisdicional quando entende que deva exercê-la. Consagrado pela Constituição Federal o sistema acusatório, onde existe separação orgânica entre o órgão acusador e o órgão julgador, não pode um usurpar a atribuição ou competência do outro. Por consequência, ao titular do ius persequendi pertence com exclusividade também a disponibilidade da ação penal quando a lei mitiga o princípio da obrigatoriedade ${ }^{94}$.

\footnotetext{
92 OLIVEIRA, Atualização da $17^{a}$ edição do curso de processo penal em virtude da Lei $n^{o}$ 12.850/13. Acesso em: 25 out. 2019.

93 PGR, Petição inicial da Ação Direta de Inconstitucionalidade $n^{\circ}$ 5.508, Supremo Tribunal Federal. Disponível em: http://www.mpf.mp.br/pgr/documentos/adi-5508. Acesso em: 25 out. 2019.

94 MIRABETE, Julio Fabbrini. Juizados especiais criminais: comentários, jurisprudência, legislação. São Paulo: Atlas, 2002. p. 153.
} 


\subsection{Prêmios Legais: a Discussão Sobre a Taxatividade do Modelo Previsto na Lei 12.850/13 e o seu Esvaziamento na Prática}

Adentrando no conteúdo em si dos acordos, será examinado agora o que lhe confere sentido e torna-os interessantes aos imputados: os prêmios legais que poderão ser conferidos. Afinal, a essência dos acordos de colaboração premiada reside no oferecimento de prêmios pelo Estado ao imputado, diminuindo sua resistência, de forma que este assinta à acusação e contribua com a persecução penal.

$\mathrm{Na}$ lei objeto de estudo, não existe um rol que elenca as hipóteses de benefícios que podem ser conferidos ao colaborador, como o faz nos possíveis resultados advindos de uma colaboração (conforme visto no item 3.1), mas as especificam na redação dos dispositivos pertencentes ao regramento legal do instituto (Seção I - Da Colaboração Premiada).

Destarte, temos as seguintes previsões legais: antes da prolação da sentença, podem as partes convencionar (a) o perdão judicial; (b) a redução da pena privativa de liberdade em até dois terços ${ }^{95}$; ou (c) a substituição da pena privativa de liberdade em restritiva de direitos (artigo $4^{\circ}$, cáput). Ainda nesta fase pré-sentença, pode também o Ministério Público (d) deixar de oferecer a denúncia se o colaborador não for o líder da organização criminosa ou se for o primeiro a prestar efetiva colaboração (artigo $4^{\circ}, \S 4^{\circ}$, incisos I e II).

Se, por outro lado, a colaboração for firmada após o sentenciamento do acusado, ora colaborador, (e) a pena poderá ser reduzida até a metade,

\footnotetext{
${ }^{95}$ Discussão pertinente sobre este ponto é que, de forma diferente às legislações anteriores, a Lei 12.850/13 não previu um mínimo para o prêmio de redução de pena. Alguns doutrinadores, como Luiz Flávio Gomes e Marcelo Rodrigues da Silva, defendem que deva-se aplicar por analogia os demais dispositivos do ordenamento brasileiro, ainda que em vigência nova legislação, para assegurar o mínimo de um terço na hipótese de redução da pena. Outros autores, como por exemplo Renato Brasileiro de Lima, tomam como parâmetro o mínimo previsto no Código Penal e na legislação especial, cujo valor é de um sexto. Sobre isso, ver: GOMES, Luiz Flávio; SILVA, Marcelo Rodrigues da. Organizações criminosas e técnicas especiais de investigação: questões controvertidas, aspectos teóricos e práticos e análise da Lei 12.850/2013. Salvador: JusPODIVM, 2015. p. 260-261;

LIMA, 2018, p. 808.
} 
ou ainda, (f) será admitida a progressão de regime ainda que ausentes os requisitos objetivos $\left(\operatorname{artigo} 4^{\circ}, \S 5^{\circ}\right)$.

Em confronto com a sistematização trazida pela lei, alguns acordos, sobretudo os realizados no bojo da operação Lava Jato têm destoado dos limites legais vistos nesse item do trabalho. Algumas benesses previstas nesses acordos, como os chamados "regimes de cumprimento de pena diferenciados" e a liberação dos bens oriundos das atividades ilícitas trazem à tona questionamentos sobre a possibilidade das partes convencionarem sobre tópicos não abarcados pela lei.

A título de exemplo, cite-se o recente acordo de colaboração na Pet 6.138 $\mathrm{STF}^{96}$, no qual a pena máxima, unificada em 20 anos de reclusão, se concedidos os benefícios, será cumprida em dois anos e três meses em "regime fechado diferenciado" e nove meses em "regime semiaberto diferenciado", cumulado com prestação de serviços à comunidade (conforme a cláusula $5^{\mathrm{a}}, \S 1^{\mathrm{o}}$ do acordo). Sendo assim, o prêmio final, além do privilégio de cumprimento nesses "regimes diferenciados", representaria uma redução de 20 anos para 3 anos, o que significa uma porcentagem de diminuição de $85 \%$, extrapolando em muito aquilo que fora designado na legislação (máximo de dois terços).

Como estes "regimes diferenciados" não encontram regulação alguma no ordenamento, suas condições são delimitadas nos próprios acordos de colaboração, muitas vezes com diversos benefícios, como cumprimento de pena domiciliar, datas previstas de ausência da residência, lista de visitantes autorizados, dentre outras ${ }^{97}$.

Outra circunstância por vezes observada é a liberação dos bens oriundos das atividades ilícitas. No acordo de colaboração premiada na Pet

\footnotetext{
96 Disponível em: https://www.conjur.com.br/dl/peca-pet-6138.pdf. Acesso em: 29 out. 2019.

97 No caso concreto analisado, foram anexados dois apensos, nos quais delimitaram-se as condições do "regime fechado diferenciado", substituindo-se o disposto nos artigos 34 do Código Penal e 87 a 90 da Lei de Execuções Penais; e do "regime semiaberto diferenciado", também em substituição aos artigos 35 do Código Penal e 91, 92 e 112 c/c 146-B, II e IV da Lei de Execuções Penais.
} 
5.244 $\mathrm{STF}^{98}$, foi permitida a permanência dos bens, frutos de crimes, com familiares do delator, como carros blindados e imóveis ${ }^{99}$. Na ocasião, a justificativa dada foi que tal ato seria uma espécie de medida de segurança aos familiares enquanto o colaborador estivesse preso, retornando depois estes bens ao poder da Justiça.

A grande questão, então, é justamente se há uma taxatividade da lei no tocante aos prêmios legais que podem ser conferidos ao colaborador; ou se as partes podem transacionar sobre quaisquer quesitos aplicando-se analogias, desde que respeitada a moralidade, licitude, dignidade da pessoa humana etc.

Adeptos à concessão de benefícios extralegais, alguns doutrinadores, como Andrey Borges de Mendonça ${ }^{100}$ e o ministro Luís Roberto Barroso ${ }^{101}$ inferem que para o colaborador ser agraciado com um benefício, basta que este não seja expressamente vedado por lei, utilizando-se da analogia in bonam partem.

\footnotetext{
${ }^{98}$ Disponível em: https://politica.estadao.com.br/blogs/fausto-macedo/wpcontent/uploads/sites/41/2015/01/acordodela\%C3\%A7\%C3\%A3oyoussef.pdf. Acesso em: 30 out. 2019.

99 “(...) se a colaboração frutífera também pode conduzir ao não oferecimento da denúncia e, por via de consequência, à impossibilidade de perda patrimonial como efeito da condenação, pareceme plausível que determinados bens do colaborador possam ser imunizados contra esse efeito no acordo de colaboração, no caso de uma sentença condenatória". BRASIL. Supremo Tribunal Federal. Habeas Corpus n ${ }^{\circ}$ 127.483/PR. Brasília, 27 ago. 2015. p. 61.

${ }^{100}$ MENDONÇA, Andrey B. Os benefícios possíveis na colaboração premiada: entre a legalidade e a autonomia da vontade. In: MOURA, Mara Thereza A.; BOTTINI, Pierpaolo C. (Coord.). Colaboração premiada. São Paulo: RT, 2017. p. 104.

101 "Se em acordo com o Ministério Público, firmado com assistência de advogado de defesa técnica e homologado pelo juiz competente, se neste acordo se der uma condição mais favorável do que aquela que esteja expressamente prevista na lei, se o juiz a aceitar e homologar, não vejo nenhum problema. E nós fazemos isso em favor do acusado, dar sanção mais benéfica do que a que está prevista em lei. Aliás, ainda na terça-feira passada, na Primeira Turma, decidiu-se, por maioria, no sentido de uma prisão domiciliar fora das situações que o Código Penal regula para a prisão domiciliar. Como era em favor do réu, e não contra o réu, a ninguém pareceu fora de propósito. Portanto, a sanção negociada, mais favorável e homologada pelo juízo, parece-me perfeitamente legítima. E por qual razão? É que, se a lei permite o não oferecimento da denúncia, se a lei permite a concessão de perdão judicial, isto é, permite que se isente o colaborador da imposição de qualquer pena, a meu ver, é intuitivo que se admita o estabelecimento de condições outras, que não resultem na total liberação do colaborador. Simplesmente porque quem pode o mais - não oferecer denúncia ou negociar o perdão judicial - pode perfeitamente negociar uma sanção mais branda do que a que consta da textualidade da lei”. STF, Voto na Questão de Ordem na Pet 7.074/DF. Plenário, Rel. Min. Edson Fachin. Data do julgamento: 22 jun. 2017. p. 7.
} 
Apesar de, a priori, possa-se crer que esta lógica de atribuir benesses não previstas na legislação atual favoreceria o réu, a bem da verdade, estamos diante de uma falácia, pois se os efeitos concretos de tal ação destoam da finalidade perseguida em sede legal, o resultado inevitável é o esvaziamento de direitos e garantias fundamentais. Ainda que em alguns casos práticos, num primeiro olhar apenas constate-se vantagens ao acusado, não podemos deixar de atentar para o fato de que, aumentando-se o poder punitivo, incontinenti diminui-se a defesa e a garantia dos direitos fundamentais.

Ao ofertar tamanha discricionariedade, abre-se margem para futuros acordos que possam não ser tão favoráveis assim aos réus. Nesse seguimento, imperioso destacar o exemplo norte-americano anteriormente visto $^{102}$, em que $95 \%$ dos casos penais resolvem-se em condenações provindas de acordos, com "benefícios" aos réus, e ainda assim trata-se do país com a maior população prisional do planeta $^{103}$. Vale ainda recordar que um dos pontos que nos permitiu diferenciar a plea bargain do sistema brasileiro da colaboração premiada foi propriamente a soberania que os promotores americanos detêm para conduzir a negociação, diversamente do que ocorre aqui.

Nas palavras de Frederico Valdez Pereira:

(...) a solução é um pouco mais complexa do que poderia sugerir um raciocínio embasado na lógica simplista de 'quem pode o mais, pode o menos', pois a relação entre sanções penais e civis é de qualidade, e não de quantidade; (...) somente a lei pode disciplinar natureza e extensão das medidas premiais, retirando, deste modo, alguma ampla discricionariedade dos órgãos repressivos, e mesmo jurisdicionais, quanto à sanção a ser aplicada ${ }^{104}$.

Com igualdade, sustenta Afrânio Silva Jardim:

\footnotetext{
102 Ver item 1.3.

${ }^{103}$ WORLD PRISON BRIEF. Disponível em: https://www.prisonstudies.org/highest-tolowest/prison-population-total?field_region_taxonomy_tid=All. Acesso em: 30 out. 2019. ${ }^{104}$ PEREIRA, 2016, p. 151.
} 
(...) o Poder Judiciário não deve homologar acordos de cooperação que consagrem 'prêmios' não autorizados na lei cogente e, com mais razão, que contrariem tal lei. Não devem ser homologadas 'delações premiadas' que prevejam cumprimento de penas altas em regimes não permitidos pela lei penal ou de execução penal, prisão domiciliar para penas de dez anos ${ }^{105}$.

Logo, os acordos de colaboração premiada, como instrumentos da justiça criminal negocial brasileira, precisam ser restringidos e necessariamente respeitar ao máximo os parâmetros estabelecidos nos diplomas legais ${ }^{106}$, buscando-se uma "cultura de legalidade dos benefícios" 107 que fora muito bem traduzida no ensinamento de Canotilho e Nuno Brandão:

\begin{abstract}
Nisto vai implicada a taxatividade do catálogo legal dos benefícios que poderão ser atribuídos ao colaborador: vantagens que não se encontrem legalmente previstas não podem ser prometidas e concedidas. Não se divisando no regime legal qualquer lacuna que careça de integração, será ainda inaceitável a outorga de privilégios extralegais com base em argumentos de identidade ou maioria de razão ou em analogia. Técnicas que, aliás, sempre seriam de reputar-se como inadmissíveis num meio de obtenção de prova que contende com direitos fundamentais de terceiros como é o caso da colaboração premiada ${ }^{108}$.
\end{abstract}

\title{
Consubstanciado nessa visão, o Ministro do STF Ricardo
}

Lewandowski deixou de homologar acordo de colaboração premiada prevendo forma de cumprimento de pena diversa da prevista legalmente, porque este "deve ser estabelecido pelo magistrado competente, nos termos do disposto no art. 33 e seguintes do Código Penal, como também no art. 387 do Código de Processo Penal, os quais configuram normas de caráter cogente, que não admitem estipulação em contrário por obra da vontade das

\footnotetext{
105 JARDIM, Afrânio Silva. Acordo de cooperação premiada. Quais são os limites? Revista Eletrônica de Direito Processual, Rio de Janeiro, ano 10, v. 17, n. 1, Jan./Jun. 2016. p. 3.

106 Nesse sentido: BOTTINO, Thiago. Colaboração premiada e incentivos à cooperação no processo penal: uma análise crítica dos acordos firmados na "Operação Lava Jato". Revista Brasileira de Ciências Criminais, São Paulo, v. 24, n. 122, agosto de 2016. p. 376;

SILVA, Marcelo R. A colaboração premiada como terceira via do direito penal no enfrentamento à corrupção administrativa organizada. Revista Brasileira de Direito Processual Penal, Porto Alegre, v. 3, n. 1, Jan./Abr. 2017. p. 310;

COSTA, 2017, p. 140.

${ }^{107}$ QUEIJO, Maria Elizabeth. O direito de não produzir provas contra si mesmo. $2^{\mathrm{a}}$ ed., São Paulo: Saraiva, 2012. p. 259.

${ }^{108}$ CANOTILHO; BRANDÃO, 2017, p. 156.
} 
partes do acordo de colaboração" e que "validar tal aspecto do acordo, corresponderia a permitir ao Ministério Público atuar como legislador"109.

Por derradeiro, vale ainda citar o disposto no Manual ENCCLA:

Também não devem ser homologadas propostas que tragam, por exemplo, local de prisão preventiva ou de cumprimento de pena, promessas de celas especiais (ressalvado o que consta do art. 5. ${ }^{\circ}$, inciso VI, da Lei 12.850/13) ou outras benesses cujo atendimento dependa de outro órgão ou autoridade, em momento presente ou futuro. Ninguém pode prometer e o juiz não pode homologar aquilo que não se saberá se poderá ser efetivado ${ }^{110}$.

Resta claro, portanto, que o mais apropriado, conforme tentou-se elucidar neste tópico, é ater-se às normas legais, afastando do acordo cláusulas que versem sobre matéria não antevista na legislação, em especial a Lei 12.850/13. Desta feita, pretende-se evitar uma possível deturpação das premissas e princípios do processo penal, o que poderia ocasionar excessos e arbitrariedades, bem como coações e inseguranças.

Apesar de parecer paradoxal, ao restringir os benefícios ao réu colaborador o que se objetiva é justamente a manutenção de seus direitos e garantias fundamentais; indubitavelmente postos em risco se dermos anuência a uma atuação irrefreada do acusador proponente.

\subsubsection{A Mitigação do Princípio da Obrigatoriedade da Ação Penal Pública}

A Constituição de 1988 designou ao Ministério Público uma gama de atribuições, dentre elas, a já mencionada anteriormente ${ }^{111}$ de "promover, privativamente, a ação penal pública, na forma da lei”, contida no artigo 129, inciso I da Carta Magna.

\footnotetext{
109 STF, Decisão monocrática na Pet 7.265/DF. Rel. Min. Ricardo Lewandowski, Data do julgamento 14 nov. 2017, p. 23. Disponível em:

http://www.stf.jus.br/arquivo/cms/noticiaNoticiaStf/anexo/PET7265.pdf. Acesso em: 30 out. 2019. ${ }^{110}$ Disponível em: $\quad$ http://www.mpf.mp.br/atuacao-tematica/sci/dados-da-atuacao/eventos2/eventos-internacionais/conteudo-banners-1/enccla/restrito/manual-colaboracao-premiadajan14.pdf/view. Acesso em: 30 out. 2019.

${ }^{111}$ Ver item 3.3.1.
} 
Diferentemente da Constituição italiana, que prevê expressamente o princípio da obrigatoriedade em seu corpo, ao estabelecer em seu artigo 112 que "Il pubblico ministero ha l'obbligo di esercitare l'azione penale"112, tal preceito, no ordenamento jurídico brasileiro, decorre da interpretação conjunta o supracitado artigo 129, inciso I, da Constituição e os artigos 24 do Código de Processo Penal ${ }^{113}$ e 100, $\S 1^{\circ}$ do Código Penal ${ }^{114}$.

O âmago deste princípio, então, é a obrigação do Parquet em oferecer a denúncia ao tomar conhecimento do fato, após apuração e colheita de indícios suficientes para embasá-la. Não pode o órgão ministerial quedar-se inerte uma vez que dispuser do necessário para proceder com a acusação penal. Ressalte-se que esta regra é atinente às ações penais públicas.

Renato Brasileiro de Lima conceitua o princípio de maneira clara:

De acordo com o princípio da obrigatoriedade da ação penal pública, também denominada de legalidade processual, aos órgãos persecutórios criminais não se reserva qualquer critério político ou de utilidade social para decidir se atuarão ou não. Assim é que, diante da notícia de uma infração penal, da mesma forma que as autoridades policiais têm a obrigação de proceder à apuração do fato delituoso, ao órgão do Ministério Público se impõe o dever de oferecer denúncia caso visualize elementos de informação quanto à existência de fato típico, ilícito e culpável, além da presença das condições da ação penal e de justa causa para a deflagração do processo criminal $^{115}$.

A atuação não discricionária está ligada ao monopólio do dever de punir que o Estado possui, vedando-se a vingança privada e o exercício arbitrário das próprias razões. Fábio Ramazzini Bechara explica o princípio nessa ótica de ser uma garantia à proteção dos interesses sociais, uma vez infringidos:

112 ITÁlIA, Costituzione della Repubblica Italiana. Disponível em: https://www.senato.it/documenti/repository/istituzione/costituzione.pdf. Acesso em: 31 out. 2019. 113 "Nos crimes de ação pública, esta será promovida por denúncia do Ministério Público, mas dependerá, quando a lei o exigir, de requisição do Ministro da Justiça, ou de representação do ofendido ou de quem tiver qualidade para representá-lo". BRASIL, Código de Processo Penal. 1941.

114 "A ação pública é promovida pelo Ministério Público, dependendo, quando a lei o exige, de representação do ofendido ou de requisição do Ministro da Justiça". BRASIL, Código Penal. 1940.

${ }^{115}$ LIMA, 2018, p. 229. 
A obrigatoriedade da ação penal representa um duplo corolário: garantir a universalidade do acesso à jurisdição a qualquer pessoa, no caso do Direito brasileiro por meio do Ministério Público; assegurar que o interesse público será tutelado de forma simétrica e indiscriminadamente. Essa dupla função da obrigatoriedade permite presumir que a ação penal constitui um mecanismo eficiente para a tutela do interesse ou direito violado ${ }^{116}$.

Este dever de punir também fica evidenciado na leitura do artigo $5^{\circ}$ do Código de Processo Penal, que por sua vez estabelece a instauração de inquérito policial de ofício, a partir da requisição de autoridade judiciária, do Ministério Público, ou a requerimento do ofendido. Cabe citar ainda a existência da ação penal privada subsidiária da pública, figura sui generis com previsão constitucional no artigo $5^{\circ}$, inciso LIX, na qual o ofendido pode ingressar com ação penal privada ainda que se trate de crime de ação pública, caso o Ministério Público não se manifeste no prazo legal, regrada também pelos artigos 100, $\S 3^{\circ}$ do Código Penal e 29 do Código de Processo Penal; admitindo-se ainda a retomada da titularidade pelo Ministério Público em casos de manifesto desinteresse do querelante no decorrer do processo.

Desta feita, após conclusão do inquérito policial, o órgão ministerial deve então agir adotando uma das "hipóteses legais de procedimento: (a) oferece denúncia; (b) requer novas diligências para sanar falhas ou lacunas; (c) requer a extinção da punibilidade do indicado; ou (d) requer o arquivamento" 117 . Não poderia o Ministério Público, em tese, afastar-se de uma dessas possibilidades. Nessa seara, por força do princípio da obrigatoriedade, não o poderia também deixar de oferecer a denúncia mediante evidências que a dessem justa causa.

Cumpre salientar que o princípio ora examinado não propende, sob nenhuma hipótese, constranger os promotores a deflagrarem a ação penal sempre, mesmo sem os indicativos necessários. Portanto, não deve-se

\footnotetext{
116 BECHARA, Fábio Ramazzini. Colaboração premiada segundo o projeto de lei das organizações criminosas. Boletim IBCCRIM, São Paulo, ano 20, nº 233, abril de 2012. p. 4.

${ }^{117}$ NUCCI, Guilherme de Souza. Princípios Constitucionais Penais e Processuais Penais. $4^{\mathrm{a}}$ ed., Rio de Janeiro: Forense, 2015.
} 
confundir o princípio da obrigatoriedade da ação penal com um "oferecimento de denúncia a todo custo".

Noutro giro, o princípio da oportunidade surge numa condição de adversidade ao da obrigatoriedade, uma vez que reflete a conveniência ou não da instauração da persecução penal. Como visto anteriormente ${ }^{118}$, os Estados Unidos adota sistemática criminal fundada neste princípio da oportunidade, materializado na plea bargain que possui grande destaque no ordenamento norte-americano.

No intuito de demonstrar as ideias contrastantes, Tourinho Filho utiliza dois axiomas para distinguir os dois princípios. Para o autor, o princípio da obrigatoriedade é pautado no "nec delicta maneant impunita (os delitos não podem ficar impunes)" ${ }^{\prime 19}$, enquanto o princípio da oportunidade calca-se no "minima non curat praetor (o Estado não se preocupa com as coisas mínimas)" 120 .

Não obstante a consolidação inconteste da obrigatoriedade como um princípio vigente no processo penal pátrio, sua sustentação se dá eminentemente por legislações infraconstitucionais e em sede doutrinária. Ocorre que, ultimamente, revela-se tendente a inserção cada vez maior de uma justiça negocial penal no cenário brasileiro. E essa inclinação, inevitavelmente, mostra-se com o potencial de mitigar o princípio obrigacional.

Quando da promulgação da Lei nº 9.099, em setembro de 1995 (Lei dos Juizados Especiais), alguns de seus dispositivos trouxeram diretrizes até então inéditas em nosso ordenamento ${ }^{121}$. A transação penal, disposta no artigo 76 da referida lei, autoriza que:

\footnotetext{
118 Ver item 1.3.

119 TOURINHO FILHO, Fernando da Costa. Processo Penal. v. 1. 35 a ed., São Paulo: Saraiva, 2013. p. 390.

120 Ibid., p. 390.

${ }^{121}$ Muito embora, como não podia deixar de ser, a Constituição já antevisse a possibilidade da transação penal em seu artigo 98, inciso I: “A União, no Distrito Federal e nos Territórios, e os Estados criarão: I - juizados especiais, providos por juízes togados, ou togados e leigos, competentes para a conciliação, o julgamento e a execução de causas cíveis de menor
} 
Havendo representação ou tratando-se de crime de ação penal pública incondicionada, não sendo caso de arquivamento, o Ministério Público poderá propor a aplicação imediata de pena restritiva de direitos ou multas, a ser especificada na proposta.

O parágrafo $2^{\circ}$ elenca as hipóteses em que não cabe a transação

penal:

$\S 2^{\circ}$ Não se admitirá a proposta se ficar comprovado:

I - ter sido o autor da infração condenado, pela prática de crime, à pena privativa de liberdade, por sentença definitiva;

II - ter sido o agente beneficiado anteriormente, no prazo de cinco anos, pela aplicação de pena restritiva ou multa, nos termos deste artigo;

III - não indicarem os antecedentes, a conduta social e a personalidade do agente, bem como os motivos e as circunstâncias, ser necessária e suficiente a adoção da medida $^{122}$.

Por sua vez, a suspensão condicional do processo (também chamada de sursis processual) encontra amparo legal no artigo 89 da mesma lei, que rege:

Nos crimes em que a pena mínima cominada for igual ou inferior a um ano, abrangidas ou não por esta Lei, o Ministério Público, ao oferecer a denúncia, poderá propor a suspensão do processo, por dois a quatro anos, desde que o acusado não esteja sendo processado ou não tenha sido condenado por outro crime, presentes os demais requisitos que autorizariam a suspensão condicional da pena ${ }^{123}$.

Grandes entraves doutrinários acerca da natureza de tais institutos surgiram à época e perduram até hoje, intensificados por jurisprudências dissonantes dos mais diversos tribunais ${ }^{124}$ : de um lado, a corrente

complexidade e infrações penais de menor potencial ofensivo, mediante os procedimentos oral e sumaríssimo, permitidos, nas hipóteses previstas em lei, a transação e o julgamento de recursos por turmas de juízes de primeiro grau." BRASIL, Constituição Federal. 1988.

122 BRASIL. Lei $n^{\circ}$ 9.099, de 26 de setembro de 1995. Dispõe sobre os Juizados Especiais Cíveis e Criminais e dá outras providências. Brasília, DF, 26 set. 1995.

${ }^{123}$ BRASIL. Lei $n^{\circ}$ 9.099, de 26 de setembro de 1995. Brasília, DF, 26 set. 1995.

124 Acerca da suspensão condicional do processo, o STF tem entendido ser obrigatória a sua aplicação, conforme precedente: "Uma vez atendidos os requisitos do artigo 89 da Lei $n^{\circ}$ 
majoritária ${ }^{125}$ que entende serem direitos subjetivos do acusado, isto é, uma vez preenchidos os requisitos deveria o Ministério Público propor a transação penal e a suspensão condicional do processo; e do outro, a corrente minoritária ${ }^{126}$ que defende ser a proposição de ambos uma discricionariedade do membro do Parquet; culminando este debate ainda numa outra questão: tais dispositivos representariam uma mitigação do princípio da obrigatoriedade?

Não se pretende nesse trabalho, ainda que o tema ostente interesse e importância, aprofundar-se em tal discussão. No entanto, há de se afirmar que, ainda que não se estabeleça um consenso sobre uma possível mitigação do princípio da obrigatoriedade - ou ainda uma "disponibilidade regrada", termo que surgiu à época ${ }^{127}$ - resta claro que tais disposições despontaram

9.099/1995, cumpre implementar a suspensão condicional do processo, podendo o Juízo atuar, nesse campo, de ofício". STF, HC 136053. Rel. Min. Marco Aurélio, primeira turma, Julgado em: 07 ago. 2018. A matéria já foi inclusive objeto de súmula: "Reunidos os pressupostos legais permissivos da suspensão condicional do processo, mas se recusando o promotor de justiça a propô-la, o juiz, dissentindo, remeterá a questão ao procurador-geral, aplicando-se por analogia o art. 28 do Código de Processo Penal." (Súmula nº 696 do STF).

Por outro lado, o STJ entende de forma diversa, conforme julgado: "(...) A suspensão condicional do processo é solução de consenso e não direito subjetivo do acusado, consoante precedentes desta Corte". STJ, AgRg no RHC 91.265/RJ. Quinta Turma. Rel. Min. Felix Fischer, Data do julgamento 27 fev. 2018. Tal entendimento resultou na tese $n^{\circ} 3$ do STJ sobre os Juizados Especiais: "A suspensão condicional do processo não é direito subjetivo do acusado, mas sim um poder-dever do Ministério Público, titular da ação penal, a quem cabe, com exclusividade, analisar a possibilidade de aplicação do referido instituto, desde que o faça de forma fundamentada".

125 Tourinho Filho, sobre o instituto da transação penal: "Uma vez satisfeitas as condições objetivas e subjetivas para que se faça a transação, aquele poderá converter-se e deverá, surgindo para o autor do fato um direito a ser necessariamente satisfeito. O Promotor não tem a liberdade de optar entre ofertar a denúncia e propor simples multa ou pena restritiva de direitos. Não se trata de discricionariedade. Formular ou não a proposta não fica à sua discrição. Ele é obrigado a formulála. E esse deverá é da Instituição. Nem teria sentido que a proposta ficasse subordinada ao belprazer, à vontade, às vezes caprichosa e frívola, do Ministério Público". TOURINHO FILHO, Fernando da Costa. Comentários à lei dos Juizados Especiais Criminais. $8^{\mathrm{a}}$ ed., São Paulo: Saraiva, 2011. p. 92.

${ }^{126}$ Sobre a suspensão condicional do processo, afirma Fernando Capez: "A iniciativa para propor a suspensão condicional do processo é uma faculdade exclusiva do Ministério Público, a quem compete promover privativamente a ação penal pública (CF, art. 129, I), não podendo o juiz da causa substituir-se a este, do mesmo modo que descabe ao magistrado, ante a recusa fundamentada do Ministério Público a requerimento de suspensão condicional do processo, o exercício de tal faculdade, visto que não se trata de direito subjetivo do réu, mas de ato discricionário do parquet." CAPEZ, Fernando. Curso de processo penal. $7^{\mathrm{a}}$ ed., rev. e ampl., São Paulo: Saraiva, 2001. p. 555. 127 Sobre isso, Ada Pelegrinni Grinover: "A discricionariedade regulada constitui resposta realista do legislador (e, em nosso sistema, do constituinte), à ideia de que o Estado moderno não pode nem deve perseguir penalmente toda e qualquer infração, sem admitir-se, em hipótese alguma, certa dose de discricionariedade na escolha das infrações penais real". GRINOVER, Ada Pelegrinni. Juizados especiais criminais - comentários à Lei 9.099/1995, de 26/09/1995. São Paulo: Revista dos Tribunais, 2002. p. 95; 
de forma a fortalecer a cultura da justiça negocial, uma vez que possuem inegavelmente um caráter despenalizador.

No mesmo sentido parece caminhar a Lei 12.850 de 2013. Entretanto, maior atenção merece esta discussão no que concerne ao instituto da colaboração premiada. Mesmo que maiores hesitações (baseadas no mesmo dissenso acima apresentado) possam surgir em relação aos demais prêmios legais previstos na Lei do Crime Organizado, um deles parece ter a capacidade de afastar quaisquer dúvidas sobre uma possível mitigação do princípio da obrigatoriedade, precisamente pelo seu caráter arrojado e assertivo.

Falamos do artigo $4^{\circ}, \S 4^{\circ}$ da lei analisada. Tal dispositivo introduziu a possibilidade do Ministério Público deixar de oferecer a denúncia se o colaborador (i) não for o líder da organização criminosa e (ii) for o primeiro a prestar efetiva colaboração. Na prática, o membro do órgão ministerial, analisando os pressupostos da necessidade e adequação, poderia deixar de promover a ação penal, em face de alguém que admitiu prática criminosa (conforme o pressuposto da confissão, visto no item 3.2.1).

Cuida-se seguramente de uma mitigação do princípio da obrigatoriedade, que no caso hipoteticamente apreciado, deixa-se de buscar a condenação de um sujeito para que se possa conseguir a de outros, desmantelando a organização criminosa; abre-se mão de uma punição que eventualmente não geraria maiores frutos positivos e edificantes em prol de um bem maior. Nas palavras de Renato Brasileiro:

Como se percebe, o legislador aí inseriu mais uma exceção ao princípio da obrigatoriedade, porquanto o órgão ministerial poderá deixar de oferecer denúncia se a colaboração levar à consecução de um dos resultados constantes dos incisos do art. $4^{\text {o128. }}$.

Não é diferente a lição de Vinicius Gomes de Vasconcellos:

No mesmo sentido: LOPES JÚNIOR, Aury. Direito Processual Penal. 13ª ed., São Paulo: Saraiva, 2016. p. 203.

${ }^{128}$ LIMA, 2018, p. 809. 
Trata-se de mecanismo que atesta cristalina expansão das exceções à regra da obrigatoriedade da ação penal pública, autorizando o não oferecimento da denúncia por critérios distintos à estrita existência de um ilícito com justa causa $^{129}$.

O chamado "acordo de imunidade" busca adaptar uma nova visão do Direito no cenário mundial em que cada vez mais as organizações criminosas estão se aperfeiçoando tecnicamente e tecnologicamente. Por essa razão, o não oferecimento da denúncia passa a ser considerado como uma alternativa que pode gerar resultados mais benéficos à sociedade como um todo.

Tal ocasião era inconcebível antes do advento da Lei 12.850/13. À luz do julgado do STF em sede da Ação Penal 470/MG, na Questão de Ordem $\mathrm{n}^{\circ} 3$, firmou-se entendimento de que seria forçoso o oferecimento da denúncia mesmo que se objetivasse a concessão do perdão judicial ao delator, o que deveria ser obtido apenas ao final de todo o trâmite processual ${ }^{130}$.

Atente-se para o fato de que estes "acordos de imunidade" apenas são possíveis se celebrados na fase de investigação preliminar, dado que após o oferecimento da denúncia, é inadmissível a desistência da ação penal pelo Parquet, conforme orientação do art. 42 do CPP, que exprime o princípio da indisponibilidade da ação penal. Em tal caso, deve-se proceder conforme orientação mencionada no parágrafo acima, intentando o benefício do perdão judicial, em equiparação.

Importante também assentar que, nos termos do $\S 12$ do mesmo artigo $4^{\circ}$, o colaborador, mesmo beneficiado pelo perdão judicial ou não denunciado, poderá ser requisitado a depor em juízo, seja por demanda das partes ou por vontade de autoridade judicial.

\footnotetext{
${ }^{129}$ VASCONCELLOS, 2018, p. 245-246;

No mesmo sentido: MENDRONI, Marcelo Batlouni. Comentários alei de Combate ao Crime Organizado: Lei n. 12.850/13. São Paulo: Atlas, 2014. p. 41;

SILVA, 2014, p. 62;

MENDONÇA, 2013, p. 20.

${ }^{130}$ STF, $A P$ 470/MG. $3^{\text {a }}$ Questão de Ordem, Rel. Min. Joaquim Barbosa, Julgado em: 23 out. 2008.
} 
Cabe frisar, por fim, que a Lei não pretende, e nem poderia, carregar uma dogmática apoiada na conveniência/oportunidade, não havendo que se falar em alargar a interpretação, estendendo-se a aplicação para demais casos que não aqueles previstos nos incisos I e II do artigo $4^{\circ}, \S 4^{\circ}$. Retomando inclusive o enunciado no item anterior, mostra-se inescusável a obediência à legalidade, uma vez que tal dispositivo versa sobre exceção do princípio da obrigatoriedade numa circunstância estritamente singular.

\subsection{Formalidades do Instrumento de Colaboração Premiada}

Os acordos de colaboração premiada, por tratarem de objetos importantes para todos os envolvidos (os direitos fundamentais do colaborador e a pretensão punitiva do Estado, por exemplo) é permeado por algumas formalidades que visam proteger as partes e darem maior legitimidade ao avençado.

Estas formalidades estão concentradas no final da Seção I da Lei 12.850 de 2013, mais especificamente nos seus artigos $6^{\circ}$ e incisos; e $7^{\circ}$ e parágrafos. Tais requisitos formais servem para ratificar os requisitos materiais aqui elencados anteriormente em item próprio, conforme se constatará a seguir.

$\mathrm{O}$ artigo $6^{\circ}$ traz a seguinte redação:

Art. $6^{\circ} \mathrm{O}$ termo de acordo da colaboração premiada deverá ser feito por escrito e conter:

I - o relato da colaboração e seus possíveis resultados;

II - as condições da proposta do Ministério Público ou do delegado de polícia;

III - a declaração de aceitação do colaborador e de seu defensor;

IV - as assinaturas do representante do Ministério Público ou do delegado de polícia, do colaborador e de seu defensor; 
V - a especificação das medidas de proteção ao colaborador e à sua família, quando necessário ${ }^{131}$.

Primeiramente, de acordo com cáput do dispositivo acima, o acordo deverá ser sempre por escrito, evitando-se contradições e demais lesões a qualquer uma das partes. Olhando para os incisos, podemos correlacionálos com algumas discussões já trazidas no decorrer do presente estudo.

Importante ressaltar, no inciso I, o termo "possíveis resultados", afirmando a ideia de que os benefícios não decorrem do acordo de forma automática, o que deve ser levado a conhecimento inequívoco do colaborador, que deverá ter ciência de sua situação, conforme dispõe o requisito da inteligência/informação.

De igual forma, o inciso II também relaciona-se a este requisito e proteção, para que, reduzindo a termo as condições do acordo pelo proponente, evita-se eventuais surpresas ou mudanças no teor que não haviam sido combinadas. Por outro lado, prestigiando o acusador, tal formalidade também permite ao acusador a efetivação do pressuposto da adequação, ou seja, com a proposta devidamente reduzida a termo, maior a facilidade para verificar a finalidade perseguida na persecução penal, quais os resultados são esperados, etc.

O inciso III, obviamente ligado ao requisito da assistência do defensor técnico, também está diretamente associado à voluntariedade do colaborador. Conforme já explicitado, a mera aceitação da proposta pelo colaborador não confere legitimidade ao requisito da voluntariedade; entretanto, o inciso III dispõe de mera formalidade do instrumento escrito, sendo indispensável tal item. Para uma inspeção material mais profunda, esse aceite deve ser analisado de forma ampla com as demais peças existentes para comprovação da real voluntariedade do colaborador.

$\mathrm{O}$ inciso IV, também relativo à necessidade de presença de um defensor técnico, imprime uma ideia além disso. Conforme Antonio 
Scarance Fernandes, este inciso prevê a chamada "dupla garantia" que devem conter os acordos no processo penal, para, que além da voluntariedade do colaborador, identifique-se também a anuência do seu $\operatorname{advogado}^{132}$.

Por último, o inciso $\mathrm{V}$ versa sobre as medidas de proteção ao colaborador e sua família, que são exemplos de direito do colaborador, conforme assegura o artigo $5^{\circ}$ da Lei.

Prosseguindo para o artigo $7^{\circ}$ e seus parágrafos, temos as seguintes disposições:

Art. $7^{\circ} \mathrm{O}$ pedido de homologação do acordo será sigilosamente distribuído, contendo apenas informações que não possam identificar o colaborador e o seu objeto.

$\S 1^{\circ}$ As informações pormenorizadas da colaboração serão dirigidas diretamente ao juiz a que recair a distribuição, que decidirá no prazo de 48 (quarenta e oito) horas.

$\S 2^{\circ} \mathrm{O}$ acesso aos autos será restrito ao juiz, ao Ministério Público e ao delegado de polícia, como forma de garantir o êxito das investigações, assegurando-se ao defensor, no interesse do representado, amplo acesso aos elementos de prova que digam respeito ao exercício do direito de defesa, devidamente precedido de autorização judicial, ressalvados os referentes às diligências em andamento.

$\S 3^{\circ} \mathrm{O}$ acordo de colaboração premiada deixa de ser sigiloso assim que recebida a denúncia, observado o disposto no art. $5^{\text {o133 }}$.

A homologação do acordo, prevista no artigo $7^{\circ}$, é o que confere legitimidade ao mesmo. Para tal, deve ser feita à luz de um lastro probatório mínimo para que se verifique os demais pressupostos e requisitos materiais e formais.

Ainda que a Lei 12.850 de 2013 , em seu artigo $4^{\circ}, \S 7^{\circ}$ diga que o juiz apenas verificará regularidade, legalidade e voluntariedade do acordo, bem como a posição do Supremo no HC 127.483/PR afirme que "o juiz, ao

132 FERNANDES, Antonio Scarance. Teoria Geral do Procedimento e o Procedimento no Processo Penal. São Paulo: RT, 2005. p. 283.

${ }^{133}$ BRASIL. Lei $n^{\circ} 12.850$ de 02 de agosto de 2013. Brasília, DF, 02 ago. 2013. 
homologar o acordo de colaboração, não emite nenhum juízo de valor a respeito das declarações eventualmente já prestadas pelo colaborador à autoridade policial ou ao Ministério Público, tampouco confere o signo da idoneidade a seus depoimentos posteriores"134, é parcialmente questionável, de certa forma leviana, essa percepção.

Primeiro, porque no campo fático, é de difícil - para não dizer quase impossível - essa distinção no exame do juiz. A linha que separa uma análise meramente formal para uma análise cognitiva mostra-se muito tênue, de maneira que, por mais que o julgador tente não adentrar no mérito da proposta, esse transpasse teórico é basicamente inevitável ao vistoriar o conteúdo ao praticar o juízo homologatório.

Isto posto, ainda que evitável fosse, deveria da mesma forma o julgador adentrar - mesmo que de forma limitada - no termo do acordo, para, assim, validar a necessidade da colaboração e quais suas contribuições à persecução penal, que é a sua verdadeira finalidade. Até porque, em certo grau, seu terreno decisório ficará adstrito àquilo que homologar, se forem cumpridas as condições do acordo no caso concreto.

O juiz deve verificar, de forma amena, a coerência dos fatos narrados e se estes estão de acordo com os demais elementos investigativos colhidos. Tal atuação visa um controle sobre a negociação, balizando por exemplo os poderes do Ministério Público acerca de cláusulas prejudiciais ou destoantes dos fatos, ou ainda, obstar acordos sobre fatos, como por exemplo os charge bargains e sentence bargains, figuras da plea bargain já estudadas no início do trabalho, que não encontram respaldo em nosso ordenamento jurídico.

\footnotetext{
${ }^{134}$ BRASIL. Supremo Tribunal Federal. Habeas Corpus no 127.483/PR. Brasília, 27 ago. 2015.
} 


\section{CAPÍTULO 4 - CRÍTICAS AO INSTITUTO}

Após todo o conteúdo apresentado, conforme já fora notado, o instituto da colaboração premiada está longe de ser uma unanimidade entre os doutrinadores e juristas; pelo contrário: trata-se de temática ainda hoje muito controversa, em diversos pontos, mesmo passados mais de seis anos desde a entrada em vigor da Lei aqui estudada.

Quase que simultaneamente à aparição da Lei 12.850, deu-se a deflagração da Operação Lava Jato, que rapidamente veio a se tornar a maior investigação em matéria de corrupção/lavagem de dinheiro já realizada no Brasil. À vista disso, desde 2014 os acordos de colaboração premiada passaram a estar muito mais em voga devido à sua ampla utilização na Lava Jato; o que não ocorria anteriormente, sendo uma ferramenta pouco utilizada, muitas vezes até pelo desconhecimento da existência de um instituto desses moldes no ordenamento pátrio.

Notoriamente, tratando-se de uma operação dessa magnitude, interesses grandiosos foram envolvidos, a mídia passou a participar mais ativamente, contribuindo para a formação da opinião pública; e consequentemente, os operadores do direito se mobilizaram e debruçaramse sobre o tema. Logo, não causa maior estranheza que se verifiquem críticas à colaboração premiada neste ínterim, umas mais temperadas e outras mais enérgicas.

Há quem entenda pela total inconstitucionalidade do instituto, taxando-o como incompatível com nosso devido processo legal, devendo assim ser excluído do nosso ordenamento. Maria Lucia Karam, por exemplo, defende a ilegitimidade da delação premiada, uma vez que esta acaba com as liberdades fundamentais, descrevendo-a como uma "venda de indulgências"135. Juarez Cerino dos Santos, por sua vez, enxerga na

\footnotetext{
${ }^{135}$ KARAM, Maria Lucia. Delação premiada: doutrina e jurisprudência. Histórico doutrinário. Rio de Janeiro: OAB-RJ, 23 ago. 2019. (Comunicação oral).
} 
colaboração premiada uma introdução à mercantilização da justiça, na qual a pena é uma espécie de mercadoria; e, do mesmo modo que John Langbein ${ }^{136}$, classifica-a, ainda, de maneira hiperbólica, como uma tortura ${ }^{137}$. Na mesma linha, Renata Rieger diz que a delação premiada deveria ser "expurgada do ordenamento jurídico brasileiro"138.

Sem embargo a posição contundente e depreciativa do instituto estampada por alguns legistas como as assentadas acima, existem quatro críticas feitas pela doutrina contrária à prática da colaboração que são as mais recorrentes. São elas: (i) a suposta coação sofrida pelo acusado para realizar o acordo de colaboração premiada; (ii) a reprovabilidade ética e moral da delação; (iii) a adoção de institutos negociais simboliza a falência estatal na sua função investigativa; e (iv) a renúncia do colaborador a alguns de seus direitos.

A principal lógica de desenvolvimento do argumento (i) na verdade pode ser estendida a todo o sistema de justiça criminal negocial: a dinâmica utilizada, de forma indissociável, acaba por gerar pressões psicológicas e coerções ao imputado para que este aceite realizar o acordo de colaboração, afastando-o assim de sua posição de resistência, ainda que não the seja favorável ou somente contra seu desejo. Haveria tendência no sentido de que, uma vez que o sistema se molde no formato negocial, tenhamos sentenças mais gravosas aos que decidirem não colaborar. Por conseguinte, existiria maior chance de condenações de inocentes que possam aderir a uma acusação infundada, tão somente por serem coagidos a tal ponto; ou ainda, a disseminação de colaborações falsas fundadas no anseio de receber o prêmio de qualquer forma.

\footnotetext{
136 “Ameaça-se o réu com uma sanção penal materialmente mais severa se houver o exercício do direito ao julgamento e posterior condenação. Essa diferença no sentenciamento é o que torna a barganha coercitiva. (...) A barganha, como a tortura, é coercitiva”. LANGBIEN, John H. Torture and plea bargaining. The University of Chicago Law Review, v. 46, n. 1, 1978. p. 12-13.

137 DOS SANTOS, Juarez Cerino. Delação premiada: doutrina e jurisprudência. Histórico doutrinário. Rio de Janeiro: OAB-RJ, 23 ago. 2019. (Comunicação oral).

138 RIEGER, Renata J. C. Breves considerações sobre o instituto da delação premiada no ordenamento jurídico brasileiro. Revista Bonijuris, v. 20, n. 537, Ago. 2008. p. 10.
} 
Esta crítica deu origem ao termo jocoso que vem sendo utilizado por adeptos dessa corrente: a colaboração premiada na verdade é uma "extorsão premiada". Assim, a voluntariedade do colaborador não se verificaria no plano dos fatos, pois o funcionamento do instituto é baseado em ameaças. Para Alberto Bovino, por exemplo, a justiça consensual importaria numa inversão lógica, já que "não foi projetada para ser utilizada aos réus confessos, mas para gerar réus confessos a quem aplicá-la"139.

A Lei 12.850/13 buscou ser bem clara, na sua redação, ao prever como um dos seus alicerces, a voluntariedade na colaboração premiada. A ausência de constrangimentos ilegais na concepção do colaborador, é, portanto, uma das suas bases, traduzindo-se em um dos requisitos mais importantes (quiçá o mais importante) para a autenticação do instrumento do acordo de colaboração. Ademais, no momento da homologação, o acordo será examinado pelo juiz, que, ao exercer jurisdição, pode inclusive manifestar sua recusa a validá-lo caso o mesmo não atenda aos requisitos legais, conforme o disposto no artigo $4^{\circ}, \S 8^{\circ}$ da lei.

Do mesmo modo, faz-se mister reforçar o regulamento da colaboração premiada, que pressupõe a corroboração da acusação por outros meios dela desligados, sem excluir a necessidade de um lastro probatório suficientemente capaz de embasar uma condenação, assim como a inafastabilidade dos atos próprios do procedimento de instrução e efetivo julgamento $^{140}$.

As objeções morais (ii) também se fazem rumorosas entre os críticos. Comumente associada ao instituto da delação premiada, a problemática ética relativa à possibilidade do Estado incentivar atitudes tidas como imorais em troca de benefícios resultantes da deslealdade, gerou a ideia de uma traição institucionalizada.

\footnotetext{
139 BOVINO, Alberto. Procedimiento abreviado y juicio por jurados. In: MAIER, Julio B. J.; BOVINO, Alberto. El procedimiento abreviado. Buenos Aires: Del Puerto, 2005. p. 77.

${ }^{140}$ SOUZA, Mariana M. Os limites e o controle dos acordos de colaboração premiada: o rei está nu, ou, em terra de cego quem tem um olho é louco? In: MENDES, Soraia da Rosa (Org.). $A$ delação/colaboração premiada em perspectiva. Brasília: IDP, 2016. p. 42.
} 
Para o professor Damásio E. de Jesus, a delação "não é pedagógica, porque ensina que trair traz benefícios" ${ }^{141}$. Aprofundando-se um pouco mais nessa linha, temos que "ao preconizar que a tomada de uma postura infame (trair) pode ser vantajosa para quem o pratica, o Estado premia a falta de caráter do codelinquente, convertendo-se em autêntico incentivador de antivalores ínsitos à ordem social" 142 .

Aqui, o argumento parece não se sustentar sob nenhuma ótica. A desaprovação do instituto que invoca tal pensamento mostra-se duplamente equivocada, pois falaciosa em dois sentidos: primeiramente, conforme já acentuado anteriormente, é dificílima a missão de apurar quais as motivações mais íntimas levaram de fato o acusado a tornar-se colaborador - de modo que nem esforçamo-nos a fazê-lo, quando da discussão acerca da necessidade de voluntariedade versus espontaneidade ${ }^{143}$. Entretanto, não pode ser descartada a possibilidade de um arrependimento pessoal. Ora, como sustentar uma crítica sob a égide da lógica e a espada da moral, contra um instituto que permite a um criminoso confesso arrepender-se de fato, e, assim, buscar suavizar os danos por ele cometidos em conluio com seus comparsas?

Não fosse só essa contradição, o que podemos inferir sobre "ética" entre criminosos? O próprio Renato Brasileiro contrapõe estas alegações, inclusive consentindo com a ideia de uma traição com respaldo oficial:

Sem embargo de opiniões em sentido contrário, parece-nos não haver qualquer violação à ética, nem tampouco à moral. Apesar de se tratar de uma modalidade de traição institucionalizada, trata-se de instituto de capital importância no combate à criminalidade, porquanto se presta ao rompimento do silêncio mafioso, além de beneficiar o acusado colaborador. De mais a mais, falar-se em ética de criminosos é algo extremamente contraditório, sobretudo se considerarmos que

\footnotetext{
${ }^{141}$ JESUS, Damásio Evangelista de. Direito Penal. São Paulo: Saraiva, 1998. p. 5.

${ }^{142}$ CARVALHO, Natália Oliveira apud LIMA, 2018, p. 795.

No mesmo sentido: VALLE, Juliano Keller do. Crítica à delação premiada: uma análise através da teoria do garantismo penal. São Paulo: Conceito Editorial, 2012. p. 114.

${ }^{143}$ Ver item 3.2.2.
} 
tais grupos, à margem da sociedade, não só têm valores próprios, como também desenvolvem suas próprias leis ${ }^{144}$.

Aliado a isso, alguns fatores como grande notoriedade que a Operação Lava Jato teve a partir da atuação midiática, bem como a grande proporção que tomou, também moldaram certas críticas. A partir do momento que os delitos investigados passaram a ser, em sua grande maioria, os ligados à administração pública e à classe política (os chamados crimes de colarinho branco) algumas condutas passam a ser moralmente reprováveis, de forma a beneficiar um ou outro lado, contaminando qualquer argumentação que pretendia ser puramente jurídica.

Não há que se falar, portanto, em desprezar a colaboração premiada fundamentando-se em supostas objeções morais. Por outro lado, uma falta de ética poderia ser mais claramente vislumbrada num recuo estatal baseado na preservação de um degenerado companheirismo nas relações criminosas. O mais adequado é sopesar, recordando que os infratores - sobretudo os beneficiados pela corrupção - desobedeceram agudamente os tais preceitos morais, e não deveriam pugnar pela observância desses entre si.

A incapacidade do Estado suscitada por uns ${ }^{145}$ (iii) tampouco merece guarida. O pressuposto da necessidade, em substância, afasta este entender. Foi explicitado que esse pressuposto visa comedir a aplicação em massa da colaboração premiada, posto que sua utilização deve ser apenas quando for crucial à persecução penal; em caráter excepcional. Quando os critérios analisados no caso concreto giram em torno da impossibilidade de se obter outras provas e da oportunidade de furar a coesão das organizações criminosas, é plenamente justificável (e mais que isso, desejável) o uso

\footnotetext{
${ }^{144}$ LIMA, 2018, p. 795.

${ }^{145}$ Nesse sentido: BITENCOURT, Cezar Roberto. Delação premiada é favor legal, mas antiético. Consultor Jurídico, publicado em 10 de junho de 2017. Disponível em: https://www.conjur.com.br/2017-jun-10/cezar-bitencourt-delacao-premiada-favor-legal-antietico. Acesso em: 08 nov. 2019.
} 
deste mecanismo. Se a colaboração ergue-se como modo eficaz de romper tais barreiras, deve ser incentivada sempre que possível ${ }^{146}$.

Seria de bom proveito, se, diversamente de apenas tentar impedir a adoção da lei, esta corrente fosse guarnecida de uma proposta igualmente eficiente. Todavia, não é o que se verifica até o momento. Nesta toada, lembre-se novamente da natureza jurídica do instituto objeto deste trabalho: meio de obtenção de provas. Subvertendo a lógica apresentada pelos críticos, não se trata de reconhecimento da falência do Estado; mas sim de mais um instrumento para obtenção de provas à disposição das autoridades, para, fazendo seu bom uso, ter o potencial de solucionar os casos que sem o auxílio da colaboração não o seria possível.

Em contrapeso às benesses as quais o colaborador pode vir a fazer jus, por óbvio, este deverá aderir à acusação e efetivamente cooperar, o que pode acabar gerando certas renúncias a alguns de seus direitos, que tanto podem ser expressas no acordo, como naturalmente decorrentes do ato de colaborar. No campo das renúncias impostas ao colaborador (iv) algumas críticas também emergem de maneira destacada.

Primeiramente, a polêmica renúncia ao direito ao silêncio. Indiscutivelmente, ao assumir o papel de colaborador, o imputado estará anuente com o fato de que deverá adotar uma postura ativa para que sua cooperação seja efetiva e dela decorra os benefícios prometidos. Esta renúncia está estampada no artigo $4^{\circ}, \S 14$ da Lei 12.850/13. Por se tratar de direito fundamental garantido constitucionalmente (artigo $5^{\circ}$, LXIII da $\mathrm{CF} / 88$ ), bem como presente também na Convenção Americana sobre Direitos Humanos (artigo $8^{\circ}, \S 2^{\circ}, \mathrm{g}$ da $\mathrm{CADH}$ ) o termo "renúncia" gera acalorados debates.

\footnotetext{
${ }^{146}$ LIMA, Márcio Barra apud FREIRE JÚNIOR, Américo Bedê; DEZAN, Willy Potrich da Silva. Delação premiada e direitos fundamentais do sujeito passivo da persecução penal a partir da regulamentação constante na Lei 12.850/2013. Revista Eletrônica de Direito Processual - REDP. Rio de Janeiro, ano 11, v. 18, n. 1, Jan./Abr. 2017, p. 54. Disponível em: publicacoes.uerj.br/index.php/redp/article/view/27822. Acesso em: 08 nov. 2019.
} 
Figurando em cláusula pétrea e sendo uma garantia fundamental, do direito ao silêncio, a princípio, não poderia se dispor. Nessa linha de pensamento, alguns pensadores defendem a incompatibilidade da colaboração premiada com a normativa constitucional eis que esta violaria o direito ao silêncio, por intermédio do supramencionado artigo da Lei 12.850/13. Assim é o entendimento de Bitencourt:

Uma vez iniciado o processo, sendo o colaborador, induvidosamente, parte no processo, goza de pleno direito ao silêncio. A lei incorrendo em grave inconstitucionalidade estabelece em seu parágrafo $14^{\circ}$ do artigo $4^{\circ}$, que o colaborador renunciará - utiliza-se voz cogente - ao direito ao silêncio, na presença de seu defensor. Ora, o dispositivo legislativo é claramente inconstitucional enquanto obriga (ou condiciona, o que dá no mesmo) o réu a abrir mão de um direito seu consagrado não apenas na constituição, como em todos os pactos internacionais de direitos humanos, dos quais o Brasil é signatário. Afinal, o réu simplesmente não está obrigado a fazer prova contra si em circunstância alguma, mesmo a pretexto de "colaborar" com a Justiça, ou seja, na condição de colaborador ${ }^{147}$.

Em contrapartida, entendendo ser possível esta renúncia, Pedro Adamy a define nos seguintes termos:

(...) pode-se afirmar que a renúncia a direito fundamental é a situação definida em lei, em que o titular do direito fundamental, expressamente, renuncia a determinadas posições ou pretensões jurídicas garantidas pelo direito fundamental, ou consente que o Poder Público restrinja ou interfira mais intensamente, por um determinado espaço de tempo e a qualquer momento revogável, tendo em vista um benefício proporcional e legítimo, direto ou indireto, pessoal ou coletivo ${ }^{148}$.

Noutro giro, alguns autores entendem que o vocábulo "renúncia" foi empregado de forma desacertada pelo legislador, eis que na realidade não se trata de renúncia propriamente dita. É o caso, por exemplo, de Andrey Borges de Mendonça e Fernando Dias:

A norma em questão, ao contrário do que sua redação literal faz crer, não previu a renúncia ao direito em si, mas apenas a obrigatoriedade de não exercício dessa

147 BITENCOURT, Cezar Roberto. Traição Bonificada. Delação premiada na "lava jato" está eivada de inconstitucionalidades. Consultor Jurídico, publicado em 4 de dezembro de 2014. Disponível em: https://www.conjur.com.br/2014-dez-04/cezar-bitencourt-nulidades-delacaopremiada-lava-jato. Acesso em: 09 nov. 2019.

${ }^{148}$ ADAMY, Pedro A. Renúncia a direito fundamental. São Paulo: Malheiros, 2011, p. 58. 
garantia pelo réu colaborador, como requisito indispensável à eficácia do $\operatorname{acordo}^{149}$.

Não é diferente o entendimento de Renato Brasileiro de Lima, que esclarece:

Parece ter havido um equívoco por parte do legislador ao fazer uso do verbo renunciar. Afinal, se se trata, o direito ao silêncio, de direito fundamental do acusado previsto na Constituição Federal e na Convenção Americana sobre Direitos Humanos, é evidente que não se pode falar em renúncia, porquanto tais direitos são, por natureza, inalienáveis (ou indisponíveis). Por consequência, o caráter indisponível do direito ao silêncio conduziria à nulidade absoluta, por ilicitude de objeto, do acordo de colaboração premiada em que fosse pactuada renúncia a esse direito. Na verdade, não há falar em renúncia ao direito ao silêncio, mas sim em opção pelo seu não exercício, opção esta exercida voluntariamente pelo investigado/acusado, que, para tanto, deverá contar com a assistência técnica de seu defensor e ser previamente informado de que não é obrigado a 'colaborar para a sua própria destruição' (nemo tenetur se detegere) $)^{150}$.

Isto posto, restou demonstrado que o direito ao silêncio, bem como o de não produzir provas contra si mesmo são compatíveis com a colaboração premiada, pois seus exercícios são plenamente respeitados. A cooperação com a Justiça em troca de prêmios legais não é compulsória. Como não há um "dever ao silêncio" e sim um direito ao silêncio, qualquer investigado pode, por sua livre vontade, confessar os fatos que lhe são imputados ${ }^{151}$. Caso o imputado deseje permanecer calado, ele não será prejudicado, mas também não será favorecido.

Outra abdicação por vezes observada no contexto dos acordos celebrados é a referente à possibilidade de recorrer de decisões processuais. A crítica que se faz é que tais disposições violam o direito de acesso à justiça, e, por consequência, acabam ferindo o devido processo legal. Ancorado nessa visão, Jorge de Figueiredo Dias afirma:

\footnotetext{
149 MENDONÇA, Andrey Borges de; DIAS, Fernando L. A renúnuncia ao direito recursal em acordo de colaboração premiada. In: SIDI, Ricardo; LOPES, Anderson B. (Org.). Temas atuais da investigação preliminar no processo penal. Belo Horizonte: D’Plácido, 2017. p. 134.

150 LIMA, 2018, p. 796.

151 Ibid., p. 796.
} 
À renúncia ao recurso no âmbito dos acordos processuais não parece estar subjacente qualquer interesse legítimo; e, pelo contrário, à sua pretendida eficácia poderiam ligar-se perigos duradouros para a subsistência de um processo penal adequado ao Estado de Direito ${ }^{152}$.

Alguns acordos chegaram a prever a renúncia total a recursos em face das sentenças condenatórias; o que foi anulado pelo STF na Pet. $\mathrm{n}^{\mathrm{o}}$ 5.244, pois se tratava de violação ao direito fundamental de acesso à Justiça, previsto no artigo $5^{\circ}, \mathrm{XXXV}$ da Constituição ${ }^{153}$.

Na mesma esteira, o habeas corpus, remédio constitucional, também foi objeto de renúncia imposta a alguns colaboradores, a saber, na Pet 5.244 (cláusula $\left.11^{\mathrm{a}}\right)^{154}$; Pet 5.210 (cláusula 12a) ${ }^{155}$; e Pet 6.138 (cláusula 19 $\left.{ }^{\mathrm{a}}\right)^{156}$, todas do STF. Nesta toada, Afrânio Silva Jardim postula que:

Seria nula qualquer cláusula que vedasse ao indiciado o direito de exercer, futuramente, o seu direito de ação, mormente em se tratando de Habeas Corpus, como seria também inválida a renúncia prévia ao duplo grau de jurisdição ${ }^{157}$.

Há corrente que defenda a legitimidade da renúncia ao direito de recorrer ${ }^{158}$. Há ainda a possibilidade de recorrer exclusivamente acerca do que não fora delimitado ou estipulado no termo. Nesse sentido, o acordo firmado no caso da JBS previa que:

As partes poderão recorrer de sentenças referentes aos fatos constantes nos anexos desse instrumento apenas naquilo que extrapolar os parâmetros deste acordo, prejudicados os recursos já interpostos com objetos diversos ${ }^{159}$.

\footnotetext{
152 DIAS, Jorge de Figueiredo. Acordos sobre a sentença em processo penal. O “fim” do Estado de Direito ou um novo "princípio"? Porto: Conselho Distrital de Porto, 2011. p. 97.

${ }^{153}$ STF, Pet 5.244. Rel. Min. Teori Zavascki, Julgado em: 19 dez. 2014. p. 117.

${ }^{154}$ Disponível em: $\quad$ https://politica.estadao.com.br/blogs/fausto-macedo/wp-

content/uploads/sites/41/2015/01/acordodela\%C3\%A7\%C3\%A3oyoussef.pdf. Acesso em: 30 out. 2019.

155 Disponível em: https://s.conjur.com.br/dl/acordo-delacao-premiada-paulo-roberto.pdf. Acesso em: 18 nov. 2019.

${ }^{156}$ Disponível em: https://www.conjur.com.br/dl/peca-pet-6138.pdf. Acesso em: 29 out. 2019.

157 JARDIM, 2016, p. 4.

${ }^{158}$ Nesse sentido: FONSECA, 2017, p. 132.

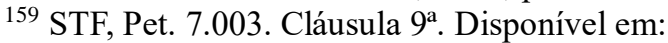

https://www.camara.leg.br/stf/Inq4483/INQ_4483_Volume_12_Fl._2.941_DVD/6_5\%20PET\%20

7003/PET\%207003/PET\%207003\%20Apenso\%2003.pdf. Acesso em: 09 nov. 2019.
} 
Essa, inclusive, é a diretriz dada pela Orientação Conjunta 1/2018 do MPF, que diz que "o acordo de colaboração deve prever a recorribilidade da sentença condenatória ou absolutória somente na parte que extrapolar os limites do acordo, como desdobramento do princípio do nemo potest venire contra factum proprium" $" 160$.

Novamente, Andrey Borges de Mendonça e Fernando Dias interpretam que na verdade não há renúncia de fato ao direito de recurso uma vez que "eventual descumprimento desse compromisso - interposição de recurso com pretensão antagônica aos termos do acordo - não afetaria o conhecimento do recurso, pois o direito recursal continua válido e, nessa condição, é irrenunciável em abstrato" "161 Sendo assim, estaríamos diante de um mero compromisso de não recorrer (cujo descumprimento pode até mesmo acarretar numa rescisão do acordo), posto que na prática é impossível cercear esse direito ao colaborador.

Pode-se concluir, portanto, que não restam dúvidas sobre as tensões perceptíveis entre o instituto da colaboração premiada e alguns princípios e garantias fundamentais, que, se não forem bem observadas à luz das balizas da legalidade, pode-se dar ensejo a abusos indesejáveis.

Esse estranhamento revela-se natural, dado que a dinâmica da colaboração premiada, bem como da justiça negocial em si, trazem dogmática um pouco distinta à metodização habitual que possuímos. Com o passar do tempo e a inserção cada vez maior de mecanismos consensuais no campo penal (o que, comprovadamente, é uma tendência que vem sendo seguida pelo nosso legislador).

As garantias tradicionais não darão respostas necessárias e adequadas, pois pensadas, criadas e implementadas para situações em que há posições antagônicas entre as partes ${ }^{162}$.

160 MINISTÉRIO PÚBLICO FEDERAL. Orientação Conjunta $n^{\circ}$ 1/2018. Acesso em: 13 set. 2019.

${ }^{161}$ MENDONÇA, 2017, p. 142

${ }^{162}$ Ibid., p. 126. 
Por conseguinte, não devemos acreditar que o problema da colaboração premiada (e da justiça negocial como um todo) é intrínseco e inevitável; e sim que "o problema não reside no instituto em si, mas no abuso ou no mau uso destes"163, sendo seus desvios eventuais equívocos de sujeitos específicos, e não defeitos cogentes.

Apesar de confirmadamente existir uma densa e legítima doutrina que sustente a inconstitucionalidade da colaboração premiada, o que vemos é um cenário no qual os personagens do campo processual penal no Brasil estão inclinados à aquiescência para com o instituto, inclusivamente com a ampliação da sua utilização. Outrossim, tal propensão vem sendo repetidamente reiterada no Supremo Tribunal Federal ${ }^{164}$.

Entretanto, este aval cedido até agora não afasta o caráter de excepcionalidade que deve ser observado quando da aplicação do instituto, amparando-se em restrições legais e limitações consolidadas, para "afastar eventual amorfismo que permita abusos e brechas para arbitrariedades"165. Neste ínterim, o que devemos almejar é uma obra da doutrina e do legislador que se proponha a preencher eventuais lacunas e solucionar inevitáveis inconveniências decorrentes da aplicação de um novo sistema.

\footnotetext{
163 SUXBERGER; MELLO, 2017, p. 211.

164 “(...) a constitucionalidade da colaboração premiada, instituída no Brasil por norma infraconstitucional na linha das Convenções de Palermo (art. 26) e Mérida (art. 37), ambas já submetidas a procedimento de internalização (Decretos 5.015/2004 e 5.687/2007, respectivamente), encontra-se reconhecida por esta Corte (...)".STF, Pet. 5.244/DF. Rel. Min. Teori Zavascki, Julgado em: 19 dez. 2014. p. 117;

STF, Pet. 5.952/DF. Rel. Min. Teori Zavascki, Julgado em: 14 mar. 2016. p. 254.

165 VASCONCELLOS, 2018, p. 42.
} 


\section{CONCLUSÃO}

Foi possível, através desse estudo, num primeiro momento, conceituar o instituto e dirimir certas confusões que têm sido feitas sobre o tema da colaboração premiada. Sua diferenciação para a delação premiada, sua natureza jurídica e sua relação com a plea bargain e o pattenggiamento serviram para situar o instituto e delimitar o campo que foi tratado.

Buscou-se também, no decorrer do presente trabalho, explorer os principais pontos do instituto da colaboração premiada trazidos pela Lei 12.850/13 e como eles estão inseridos no combate à criminalidade sofisticada que é praticada na contemporaneidade. As controvérsias e incertezas indicadas por parte da doutrina contrária ao seu emprego foram expostas e contrapostas, no sentido de acenar para uma favorável aplicação do mecanismo, conforme os argumentos assentados.

Restou evidenciado, sem espaço para dúvidas, que o país vem se inclinando para uma expansão do modelo negocial, seja pelas opções do legislador em introduzir tais conteúdos nas normas legais, seja pela postura majoritaria dos tribunais de base e superiors em garantir a plena utilização de tais acordos, reafirmando sua harmonia com os mandamentos constitucionais. Devido aos resultados obtidos, não só a postura tende em permanecer nessa anuência, como também vislumbra-se a possibilidade de alargamento dessa modalidade, ainda nova em nossa realidade processual.

Entretanto, diante dessa tendência do ordenamento e dos juristas, bem como de uma vontade latent da sociedade em busca de resultados cada vez mais rápidos e contundentes, devemos assumir uma postura cautelosa. Conforme demonstrado durante várias fases deste texto, a colaboração premiada deve possuir o caráter de necessidade e excepcionalidade, sendo repudiada sua aplicação genérica e excessiva, o que dificultaria o controle de suas condições e as garantias fundamentais que estão interligadas à prática negocial entrariam em risco. 
De igual forma, desejando afastar qualquer ameaça a estes direitos, a colaboração premiada deve estar, a todo momento, coadunável com o princípio da legalidade, de maneira que não existam brechas que ensejem a violação de tais preceitos em decorrência de uma má aplicação do instituto; o que não faria sentido, posto que este coloca-se como uma ferramenta do Estado para justamente fazer valer diversos direitos conferidos aos cidadãos.

Consoante ao que foi asseverado em relação às respeitáveis críticas ao instituto trazidas à baila no capítulo final, podemos afirmar com segurança que a colaboração premiada está em concordância com a ordem constitucional, e que não pretende, de forma alguma, estabelecer prioridades ou distribuir impunidades entre os acusados; mas sim proporcionar aos órgãos e autoridades que subsistam em suas funções investigativas e persecutórias diante do inegável refinamento que aliou-se aos grupos criminosos nos últimos anos, exigindo maior gabarito e criatividade na atuação estatal nestas áreas.

Nesse sentido, concluímos que a colaboração premiada não pode se tornar barganha ${ }^{166}$, devendo-se respeitar todas as fases inerentes ao processo penal tal qual conhecemos, para que não caiamos no erro de transformar os institutos negociais em uma forma de excluir o processo, sendo esse utilizado somente para validar os depoimentos do colaborador. Segundo o brilhante professor Eugênio Pacelli:

Há que se observar que a colaboração premiada no Brasil não dispensa a sentença condenatória, isto é, ela depende da apreciação de todos os fatos e provas, ao final do que somente a procedência da acusação é o que permitirá a aplicação da pena assim negociada ${ }^{167}$.

Em síntese, a colaboração premiada, muito controversa na doutrina e jurisprudência, deve sim ser utilizada, porém com muita responsabilidade. Devido aos polos envolvidos e as consequências resultantes de uma 
aplicação atécnica, não cabem interpretações extensivas dos dispositivos que a regulamenta, e a estrita observância à legalidade se faz necessária, bem como a limitação das disposições contidas nos acordos.

Em algum momento da nossa sociedade, as autoridades deixaram-se descuidar: foi quando as organizações criminosas obtiveram modernização e inteligência. Todavia, se empregada em conformidade com o exposto acima e nos critérios mais profundamente esmiuçados no decurso de todo esse trabalho, temos em mãos um útil instrumento para satisfazer as pretensões legítimas do Estado e combater essas atividades abomináveis, tão malignas e reprováveis num país como o que vivemos, em que faltam insumos básicos para muitos, enquanto outros locupletam-se em desvantagem destes, valendo-se das mais diversificadas e engenhosas práticas, que, ao invés de serem empregadas para o bem, têm como objeto aspirações criminosas. 


\section{REFERÊNCIAS BIBLIOGRÁFICAS}

ADAMY, Pedro A. Renúncia a direito fundamental. São Paulo: Malheiros, 2011.

AIRES, Murilo T.; FERNANDES, Fernando A. A colaboração premiada como instrumento de política criminal: a tensão em relação às garantias fundamentais do réu colaborador. Revista Brasileira de Direito Processual Penal, v. 3, n. 1. Porto Alegre, Jan./Abr. 2017.

ALMEIDA, Candido Mendes de. Codigo Philippino ou Ordenações e leis do Reino de Portugal: recopiladas por mandado d'El Rey D. Philippe I. Rio de Janeiro: Typ. Do Instituto Philomathico. 1870.

AMODIO, Ennio. Processo penale, diritto europeo e common law. Dal rito inquisitorio al giusto processo. Milano: Giuffrè, 2003.

ANSELMO, Márcio A. Colaboração premiada. O novo paradigma do processo penal brasileiro. Doutrina e prática. A visão do delegado de polícia. Rio de Janeiro: Mallet, 2016.

ARAS, Vladimir. Lavagem de dinheiro: prevenção e controle penal. CARLI, Carla Veríssimo de (Org.). Porto Alegre: Editora Verbo Jurídico, 2011.

ARRUDA, Rejane Alves de; PEREIRA, Ricardo Souza. (Org.). Organização Criminosa - comentário à lei 12.850/13, de 05 de agosto de 2013. Rio de Janeiro: Lumen Juris, 2013.

BADARÓ, Gustavo. Processo Penal. Rio de Janeiro: Campus, 2012.

; BOTTINI, Pierpaolo. Lavagem de dinheiro. Aspectos penais e processuais penais. São Paulo: RT, 2013.

BECHARA, Fábio Ramazzini. Colaboração premiada segundo o projeto de lei das organizações criminosas. Boletim IBCCRIM, São Paulo, ano 20, $\mathrm{n}^{\circ}$ 233, abril de 2012.

Colaboração processual: legalidade e valor probatório. Boletim IBCCrim, São Paulo, ano 23, v. 269, 2015. 
BEZERRA, Edson A.; MELLO, Luis Fernando. Colaboração premiada: um instituto questionável para a produção de provas. Iurisprudentia, Juína, a. 5, n. 9, p. 9-42, Jan./Jun. 2016.

BITENCOURT, Cezar Roberto. Delação premiada é favor legal, mas antiético. Consultor Jurídico, publicado em 10 de junho de 2017. Disponível em: https://www.conjur.com.br/2017-jun-10/cezar-bitencourtdelacao-premiada-favor-legal-antietico. Acesso em: 08 nov. 2019.

Traição Bonificada. Delação premiada na "lava jato" está eivada de inconstitucionalidades. Consultor Jurídico, publicado em 4 de dezembro de 2014. Disponível em: https://www.conjur.com.br/2014-dez-04/cezarbitencourt-nulidades-delacao-premiada-lava-jato. Acesso em: 09 nov. 2019.

; BUSATO, Paulo Cesar. Comentários à Lei de Organização Criminosa: Lei n.12.850/2013. São Paulo: Saraiva, 2014.

BITTAR, Walter Barbosa. A delação premiada no Brasil. In: BITTAR, Walter Barbosa (Coord.) Delação premiada. Direito estrangeiro, doutrina e jurisprudência. Rio de Janeiro: Lumen Juris, 2011.

BOTTINO, Thiago. Colaboração premiada e incentivos à cooperação no processo penal: uma análise crítica dos acordos firmados na "Operação Lava Jato". Revista Brasileira de Ciências Criminais, São Paulo, v. 24, n. 122, agosto de 2016.

BOVINO, Alberto. Procedimiento abreviado y juicio por jurados. In: MAIER, Julio B. J.; BOVINO, Alberto. El procedimiento abreviado. Buenos Aires: Del Puerto, 2005.

BRASIL, Código de Processo Penal. 1941.

BRASIL, Código Penal. 1940.

BRASIL, Constituição Federal. 1988.

BRASIL. Lei 9034/95. Lei Complementar 105/01. Superveniente. Hierarquia superior. Revogação implícita. Ação prejudicada, em parte. "Juiz de Instrução". Realização de diligências pessoalmente. Competência para investigar. Inobservância do devido processo legal. Imparcialidade do magistrado. Ofensa. Funções de investigar e inquirir. Mitigação das atribuições do Ministério Público e das Polícias Federal e Civil. Disponível em:

http://stf.jus.br/portal/jurisprudencia/listarJurisprudencia.asp?s1=\%28ADI\% 
24\%2ESCLA $\% 2 \mathrm{E}+\mathrm{E}+1570 \% 2 \mathrm{ENUME} \% 2 \mathrm{E} \% 29+\mathrm{OU}+\% 28 \mathrm{ADI} \% 2 \mathrm{EACM}$ $\mathrm{S} \% 2 \mathrm{E}+\mathrm{ADJ} 2+1570 \% 2 \mathrm{EACMS} \% 2 \mathrm{E} \% 29 \&$ base=baseAcordaos\&url=http://t inyurl.com/c5jws8j. Acesso em: 18 nov. 2019.

BRASIL. Lei $n^{o} 10.409$ de 11 de janeiro de 2002. Dispõe sobre a prevenção, o tratamento, a fiscalização, o controle e a repressão à produção, ao uso e ao tráfico ilícitos de produtos, substâncias ou drogas ilícitas que causem dependência física ou psíquica, assim elencados pelo Ministério da Saúde, e dá outras providências. Brasília, DF, 11 jan. 2002.

Lei $n^{o} 11.343$ de 23 de agosto de 2006. Institui o Sistema Nacional de Políticas Públicas sobre Drogas - Sisnad; prescreve medidas para prevenção do uso indevido, atenção e reinserção social de usuários e dependentes de drogas; estabelece normas para repressão à produção não autorizada e ao tráfico ilícito de drogas; define crimes e dá outras providências. Brasília, DF, 23 ago. 2006.

Lei $n^{o} 12.850$ de 02 de agosto de 2013. Dispõe sobre a prevenção, o tratamento, a fiscalização, o controle e a repressão à produção, ao uso e ao tráfico ilícitos de produtos, substâncias ou drogas ilícitas que causem dependência física ou psíquica, assim elencados pelo Ministério da Saúde, e dá outras providências. Brasília, DF, 02 ago. 2013.

Lei $n^{o} 12.850$ de 11 de janeiro de 2002. Dispõe sobre a prevenção, o tratamento, a fiscalização, o controle e a repressão à produção, ao uso e ao tráfico ilícitos de produtos, substâncias ou drogas ilícitas que causem dependência física ou psíquica, assim elencados pelo Ministério da Saúde, e dá outras providências. Brasília, DF, 11 de janeiro de 2002.

Lei $n^{o} 8.072$ de 25 de julho de 1990. Dispõe sobre os crimes hediondos, nos termos do art. $5^{\circ}$, inciso XLIII, da Constituição Federal, e determina outras providências. Brasília, DF, 25 jul. 1990.

Lei $n^{\circ} 8.137$ de 27 de dezembro de 1990. Define crimes contra a ordem tributária, econômica e contra as relações de consumo, e dá outras providências. Brasília, DF, 27 dez. 1990.

Lei $n^{\circ} 9.034$ de 3 de maio de 1995. Dispõe sobre a utilização de meios operacionais para a prevenção e repressão de ações praticadas por organizações criminosas. Brasília, DF, 3 mai. 1995.

Lei $n^{\circ}$ 9.099, de 26 de setembro de 1995. Dispõe sobre os Juizados Especiais Cíveis e Criminais e dá outras providências. Brasília, DF, 26 set. 1995. 
Lei $n^{o} 9.613$ de 3 de março de 1998. Dispõe sobre os crimes de "lavagem" ou ocultação de bens, direitos e valores; a prevenção da utilização do sistema financeiro para os ilícitos previstos nesta Lei; cria o Conselho de Controle de Atividades Financeiras - COAF, e dá outras providências. Brasília, DF, 3 mar. 1998.

Lei $n^{\circ} 9.807$ de 13 jul. 1999. Estabelece normas para a organização e a manutenção de programas especiais de proteção a vítimas e a testemunhas ameaçadas, institui o Programa Federal de Assistência a Vítimas e a Testemunhas Ameaçadas e dispõe sobre a proteção de acusados ou condenados que tenham voluntariamente prestado efetiva colaboração à investigação policial e ao processo criminal. Brasília, DF, 13 jul. 1999.

Projeto de Lei $n^{o}$ 209, de 2003 (do Senado Federal). Dá nova redação a dispositivos da Lei $\mathrm{n}^{\circ}$ 9.613, de 3 mar. 1998, objetivando tornar mais eficiente a persecução penal dos crimes de lavagem de dinheiro. Brasília, DF, 8 mai. 2008. Disponível em: https://www25.senado.leg.br/web/atividade/materias/-/materia/58211. Acesso em: 02 set. 2019.

Superior Tribunal de Justiça. Agravo Regimental no Agravo de Instrumento $n^{o}$ 1.285.269/MG, $6^{\mathrm{a}}$ Turma, Rel. Min. Og Fernandes, julgado em 4 nov. 2010. Disponível em: https://stj.jusbrasil.com.br/jurisprudencia/17584427/agravo-regimental-noagravo-de-instrumento-agrg-no-ag-1285269-mg-2010-0041883-6/inteiroteor-17584428?ref=juris-tabs. Acesso em: 13 set. 2019.

Superior Tribunal de Justiça. Recurso em Habeas Corpus $n^{o}$ 69.988/RJ. Recorrente: Artur Cruz Junior e outros. Recorrido: Ministério Público do Estado do Rio de Janeiro. Rel. Min. Reynaldo Soares da Fonseca. Brasília, 25 out. 2016.

Superior Tribunal de Justiça. Recurso Especial n ${ }^{o} 1.102 .736 / S P .5^{\mathrm{a}}$ Turma, Rel. Min. Laurita Vaz, julgado em 4 mar. 2010. Disponível em: https://stj.jusbrasil.com.br/jurisprudencia/19152204/recurso-especial-resp1102736-sp-2008-0264316-6-stj. Acesso em: 13 set. 2019.

. Superior Tribunal de Justiça. Recurso Especial $n^{o}$ 628.048/SP. $5^{\mathrm{a}}$ Turma, Rel. Min. Arnaldo Esteves Lima, julgado em 24 mar. 2009. Disponível em:

https://ww2.stj.jus.br/processo/revista/inteiroteor/?num_registro=20040011 8156\&dt_publicacao=13/04/2009. Acesso em: 25 out. 2019. 
Supremo Tribunal Federal. Habeas Corpus $n^{o}$ 127.483/PR. Paciente: Erton Medeiros Fonseca. Impetrante: José Luiz Oliveira Lima e outros. Rel. Min. Dias Toffoli. Brasília, 27 ago. 2015.

Supremo Tribunal Federal. Habeas Corpus $n^{o}$ 129.877/RJ. $1^{\mathrm{a}}$ Turma, Rel. Min. Marco Aurélio, julgado em 18/04/2017. Disponível em: http://portal.stf.jus.br/processos/downloadPeca.asp?id=312161444\&ext=.pd f. Acesso em: 22 out. 2019.

Supremo Tribunal Federal. Petição $n^{o}$ 5.210/DF. Decisão monocrática, Rel. Min. Teori Zavascki, julgado em 16 jun. 2016. Disponível em: https://www.conjur.com.br/dl/teori-mpf.pdf. Acesso em: 11 set. 2019.

. Supremo Tribunal Federal. Petição $n^{o}$ 7.074/DF. Distrito Federal. Relator: Ministro Edson Fachin. DJ: 29 jun. 2017.

- Supremo Tribunal Federal. Ação Direta de Inconstitucionalidade $n^{o}$ 5.508. Voto Min. Rel. Marco Aurélio. Disponível em:

http://www.stf.jus.br/arquivo/cms/noticiaNoticiaStf/anexo/ADI5508MMA. pdf. Acesso em: 25 out. 2019.

. Supremo Tribunal Federal. AP 470/MG. $3^{\mathrm{a}}$ Questão de Ordem, Rel. Min. Joaquim Barbosa, Julgado em: 23 out. 2008.

Supremo Tribunal Federal. Decisão monocrática na Pet 7.265/DF. Rel. Min. Ricardo Lewandowski, Data do julgamento: 14 nov. 2017, p. 23. Disponível

em: http://www.stf.jus.br/arquivo/cms/noticiaNoticiaStf/anexo/PET7265.pdf. Acesso em: 30 out. 2019.

. Supremo Tribunal Federal. HC 136053. Rel. Min. Marco Aurélio, primeira turma, Julgado em: 07 ago. 2018.

Supremo Tribunal Federal. Pet 5.244. Rel. Min. Teori Zavascki, Julgado em: 19 dez. 2014.

- Supremo Tribunal Federal. Pet. 5.244/DF. Rel. Min. Teori Zavascki, Julgado em: 19 dez. 2014.

- Supremo Tribunal Federal. Pet. 5.952/DF. Rel. Min. Teori Zavascki, Julgado em: 14 mar. 2016. 
Supremo Tribunal Federal. Pet. 7.003. Cláusula 9ª Disponível em:

https://www.camara.leg.br/stf/Inq4483/INQ_4483_Volume_12_Fl._2.941_ DVD/6_5\%20PET\%207003/PET\%207003/PET\%207003\%20Apenso\%200 3.pdf. Acesso em: 09 nov. 2019.

. Supremo Tribunal Federal. Voto na Questão de Ordem na Pet 7.074/DF. Plenário, Rel. Min. Edson Fachin. Data do julgamento: 22 jun. 2017.

Superior Tribunal de Justiça. AgRg no RHC 91.265/RJ. Quinta Turma. Rel. Min. Felix Fischer, Data do julgamento: 27 fev. 2018.

- Tribunal de Justiça do Distrito Federal. Apelação Criminal $n^{o}$ 20170610089843-DF (0008817-73.2017.8.07.0006). Apelante: Carlos Daniel Araujo Rodrigues. Apelado: Ministério Público do Distrito Federal e Territórios. Rel. Desembargador Waldir Leôncio Lopes Júnior. Brasília, 19 jul. 2018.

BRITO, Michelle B. Delação premiada e decisão penal: da eficiência à integridade. Belo Horizonte: D'Plácido, 2016.

CANOTILHO, J. J. Gomes; BRANDÃO, Nuno. Colaboração premiada: reflexões críticas sobre os acordos fundantes da Operação Lava Jato. Revista Brasileira de Ciências Criminais, São Paulo, v. 133, ano 25, julho de 2017.

Direito Constitucional e teoria da constituição. $2^{\mathrm{a}}$ ed., Coimbra: Almedina, 1998.

CAPEZ, Fernando. Curso de direito penal: parte geral: v. 1. 16 ${ }^{\mathrm{a}}$ ed., São Paulo: Saraiva, 2012.

2001.

Curso de processo penal. $7^{\mathrm{a}}$ ed., rev. e ampl., São Paulo: Saraiva,

CARVALHO, Paulo Roberto Galvão; MENDONÇA, Andrey Borges de. Lei de Drogas: Lei 11.343 de 23 de agosto de 2006 - Comentada artigo por artigo. São Paulo: Método, 2012.

CAVALI, Marcelo Costenaro. Duas faces da colaboração premiada: visões "conservadora" e "arrojada" do instituto na Lei 12.850/2013. In: MOURA, Mara Thereza A.; BOTTINI, Pierpaolo C. (Coord.). Colaboração premiada. São Paulo: RT, 2017. 
COSTA, Leonardo Dantas. Delação premiada. A atuação do Estado e a relevância da voluntariedade do colaborador com a justiça. Curitiba: Juruá, 2017.

CRUZ, Flávio A. Plea bargaining e delação premiada: algumas perplexidades. Revista jurídica da Escola Superior de Advocacia da OABPR, Curitiba, v. 1, n. 2, Dez. 2016.

CUNHA, Rogério Sanches; PINTO, Ronaldo Batista. Crime Organizado comentários à nova lei sobre o Crime Organizado - lei 12.850/13. Salvador: Juspodivm. 2013.

DEMERCIAN, Pedro H. A colaboração premiada e a lei das organizações criminosas. Revista jurídica ESMP-SP, v. 9, nº 1, Jan./Jun. 2016.

DIAS, Jorge de Figueiredo. Acordos sobre a sentença em processo penal. O "fim" do Estado de Direito ou um novo "princípio"? Porto: Conselho Distrital de Porto, 2011.

DIDIER JÚNIOR, Freddie; BOMFIM, Daniela. Colaboração premiada (Lei n. 12.850/2013): natureza jurídica e controle da validade por demanda autônoma - um diálogo com o Direito Processual Civil. Civil Procedure Review, v. 7, n. 2, Mai./Ago. 2016.

Disponível em: https://politica.estadao.com.br/blogs/fausto-macedo/wpcontent/uploads/sites/41/2015/01/acordodela\%C3\%A7\%C3\%A3oyoussef.p df. Acesso em: 30 out. 2019.

Disponível em: https://s.conjur.com.br/dl/acordo-delacao-premiada-pauloroberto.pdf. Acesso em: 18 nov. 2019.

Disponível em: https://www.conjur.com.br/dl/peca-pet-6138.pdf. Acesso em: 29 out. 2019.

Disponível em: http://www.mpf.mp.br/atuacao-tematica/sci/dados-daatuacao/eventos-2/eventos-internacionais/conteudo-banners1/enccla/restrito/manual-colaboracao-premiada-jan14.pdf/view. Acesso em: 30 out. 2019.

DOS SANTOS, Juarez Cerino. Delação premiada: doutrina e jurisprudência. Histórico doutrinário. Rio de Janeiro: OAB-RJ, 23 ago. 2019. (Comunicação oral). 
ESSADO, Tiago C. Delação premiada e idoneidade probatória. Revista Brasileira de Ciências Criminais, São Paulo, ano 21, v. 101, 2013.

FERNANDES, Antonio Scarance. Teoria Geral do Procedimento e o Procedimento no Processo Penal. São Paulo: RT, 2005.

FILIPPETTO, Rogério; ROCHA, Luísa C. V. C. Colaboração premiada: contornos segundo o sistema acusatório. Belo Horizonte: D'Plácido, 2017.

FIND LAW. Plea Bargains: In Depth. Disponível em: https://criminal.findlaw.com/criminal-procedure/plea-bargains-indepth.html. Acesso em: 21 ago. 2019.

FONSECA, Cibele B. G. Colaboração premiada. Belo Horizonte: Del Rey, 2017.

FREIRE JÚNIOR, Américo Bedê; DEZAN, Willy Potrich da Silva. Delação premiada e direitos fundamentais do sujeito passivo da persecução penal a partir da regulamentação constante na Lei 12.850/2013. Revista Eletrônica de Direito Processual - REDP. Rio de Janeiro, ano 11, v. 18, n. 1, Jan./Abr. 2017, p. 54. Disponível em: https://www.epublicacoes.uerj.br/index.php/redp/article/view/27822. Acesso em: 08 nov. 2019.

FUNDAÇÃO FERNANDO HENRIQUE CARDOSO. Delação premiada: uma comparação entre Estados Unidos e Brasil. Disponível em: https://fundacaofhc.org.br/iniciativas/debates/delacao-premiada-umacomparacao-entre-estados-unidos-e-brasil. Acesso em: 20 ago. 2019.

GOMES, Luiz Flavio. Coordenador e autor responsável. Lei de drogas comentada. $3^{a}$ ed., São Paulo: RT, 2008.

. Crime organizado: que se entende por isso depois da Lei $n^{o}$ 10.217/01? Apontamentos sobre a perda de eficácia de grande parte da Lei 9.034/95. Jus Navigandi, Teresina, ano 7, n. 56, 1 abr. 2002. Disponível em: http://jus.com.br/artigos/2919. Acesso em: 30 ago. 2019.

; SILVA, Marcelo Rodrigues da. Organizações criminosas $e$ técnicas especiais de investigação: questões controvertidas, aspectos teóricos e práticos e análise da Lei 12.850/2013. Salvador: JusPODIVM, 2015.

GRINOVER, Ada Pelegrinni. Juizados especiais criminais - comentários à Lei 9.099/1995, de 26/09/1995. São Paulo: Revista dos Tribunais, 2002. 
GUIDI, José Alexandre Marson. Delação Premiada no combate ao crime Organizado. França Lemos \& Cruz, 2006.

ITÁLIA, Costituzione della Repubblica Italiana. Disponível em: https://www.senato.it/documenti/repository/istituzione/costituzione.pdf. Acesso em: 31 out. 2019.

JARDIM, Afrânio Silva. Acordo de cooperação premiada. Quais são os limites? Revista Eletrônica de Direito Processual, Rio de Janeiro, ano 10, v. 17, n. 1, Jan./Jun. 2016.

JESUS, Damásio Evangelista de. Direito Penal. São Paulo: Saraiva, 1998.

KARAM, Maria Lucia. Delação premiada: doutrina e jurisprudência. Histórico doutrinário. Rio de Janeiro: OAB-RJ, 23 ago. 2019. (Comunicação oral).

LANGBIEN, John H. Torture and plea bargaining. The University of Chicago Law Review, v. 46, n. 1, 1978.

LAUAND, Mariana de Souza Lima. $O$ valor probatório da colaboração processual. Dissertação (Mestrado em Direito). Faculdade de Direito, Universidade de São Paulo, São Paulo, 2008.

LEAL, Celso Costa Lima Verde. Aspectos procedimentais da delação premiada e a nova lei de lavagem de dinheiro. In: Capacitar. VII Curso de ingresso e vitaliciamento para Procuradores da República. Brasília: ESPMU, 2011.

LEISNER, Walter. Die Gesetzmäßigkeit der Verfassung. Schriften zu Staatslehre und Staatsrecht 1957-1991. Berlin: Duncker \& Humblot, 1994.

LEMOS, Bruno E.; QUINTIERE, Victor M. Técnicas especiais de investigação no processo penal. Belo Horizonte: D'Plácido, 2017.

LIMA, Renato Brasileiro de. Manual de Processo Penal. $2^{\mathrm{a}}$ ed., rev. ampl. e atual. Salvador: JusPODIVM, 2014.

Manual de Processo Penal. Salvador: Juspodivm, 2018.

LOPES JÚNIOR, Aury. Direito Processual Penal. $13^{\text {a }}$ ed., São Paulo: Saraiva, 2016. 
MATIAS, Flávio Pereira da Costa. Sistema de Justiça Criminal. Brasília: Escola Superior do Ministério Público da União. 2018.

MENDONÇA, Andrey B. Os benefícios possíveis na colaboração premiada: entre a legalidade e a autonomia da vontade. In: MOURA, Mara Thereza A.; BOTTINI, Pierpaolo C. (Coord.). Colaboração premiada. São Paulo: RT, 2017.

A colaboração premiada e a nova Lei do Crime Organizado (Lei 12.850/13). Revista Custos Legis, v. 04, 2013.

; DIAS, Fernando L. A renúnuncia ao direito recursal em acordo de colaboração premiada. In: SIDI, Ricardo; LOPES, Anderson B. (Org.). Temas atuais da investigação preliminar no processo penal. Belo Horizonte: D’Plácido, 2017.

MENDRONI, Marcelo Batlouni. Comentários alei de Combate ao Crime Organizado: Lei n. 12.850/13. São Paulo: Atlas, 2014.

MINISTÉRIO PÚBLICO FEDERAL. Orientação Conjunta $n^{\circ}$ 1/2018. Dispõe sobre os acordos de colaboração premiada. $2^{\mathrm{a}}$ e $5^{\mathrm{a}}$ Câmaras de Coordenação e Revisão - Combate à Corrupção. Brasília, 23 de maio de 2018. Disponível em: http://www.mpf.mp.br/atuacaotematica/ccr5/orientacoes/orientacao-conjunta-no-1-2018.pdf. Acesso em: 13 set. 2019.

MIRABETE, Julio Fabbrini. Juizados especiais criminais: comentários, jurisprudência, legislação. São Paulo: Atlas, 2002.

MORO, Sérgio Fernando. Crime de lavagem de dinheiro. São Paulo: Saraiva, 2010.

NUCCI, Guilherme de Souza. Código de Processo Penal Comentado. $5^{\mathrm{a}}$ ed., São Paulo, 2006.

O valor da confissão como meio de prova no processo penal. São Paulo: RT, 1997.

Princípios Constitucionais Penais e Processuais Penais. $4^{\mathrm{a}}$ ed., Rio de Janeiro: Forense, 2015.

OLIVEIRA, Eugênio Pacelli de. Atualização da $17^{a}$ edição do curso de processo penal em virtude da Lei $n^{o}$ 12.850/13. Disponível em: 
http://www.criminal.mppr.mp.br/arquivos/File/ANEXOS/INF_264_Organi zacoes_criminosas_pacelli.pdf. Acesso em: 25 out. 2019.

PACELli, Eugênio. Curso de Processo Penal. 20ª ed., São Paulo: Atlas, 2016.

PASCHOAL, Janaína Conceição. Breves Apontamentos Relativos ao Instituto do 'Plea Bargaining' no Direito Norte-Americano. Revista do Curso de Direito do Centro Universitário das Faculdades Metropolitanas Unidas - UniFMU, ano XV, no 23, 2001.

PEREIRA, Frederico Valdez. Delação Premiada. Legitimidade e Procedimento. $3^{\text {a }}$ ed. Curitiba: Juruá, 2016.

PGR, Petição inicial da Ação Direta de Inconstitucionalidade $n^{o}$ 5.508, Supremo Tribunal Federal. Disponível em:

http://www.mpf.mp.br/pgr/documentos/adi-5508. Acesso em: 25 out. 2019.

QUEIJO, Maria Elizabeth. $O$ direito de não produzir provas contra si mesmo. $2^{\text {a }}$ ed., São Paulo: Saraiva, 2012.

RIEGER, Renata J. C. Breves considerações sobre o instituto da delação premiada no ordenamento jurídico brasileiro. Revista Bonijuris, v. 20, n. 537, Ago. 2008.

ROMERO, Eneas. A colaboração premiada. In: AMBOS, Kai; ROMERO, Eneas (Coord.). Crime organizado. Análise da Lei 12.850/2013. São Paulo: Marcial Pons, 2017.

SANTOS, Marcos Paulo Dutra. Colaboração (delação) premiada. Salvador: Juspodivm, 2016.

Colaboração unilateral premiada como consectário lógico das balizas constitucionais do devido processo legal brasileiro. Revista Brasileira de Direito Processual Penal. Porto Alegre, v.3, nº1, Jan./Abr. 2017.

SÉRGIO SOBRINHO, Mário. O crime organizado no Brasil. In: FERNANDES, Antonio Scarance; ALMEIDA, José Raul Gavião; MORAES, Maurício Zanoide de (coord.). Crime organizado: aspectos processuais. São Paulo: RT, 2009.

SILVA, Eduardo Araújo da. Organizações Criminosas. Aspectos penais e processuais da lei n. 12.850/13. São Paulo: Atlas, 2014. 
SILVA, Marcelo R. A colaboração premiada como terceira via do direito penal no enfrentamento à corrupção administrativa organizada. Revista Brasileira de Direito Processual Penal, Porto Alegre, v. 3, n. 1, Jan./Abr. 2017.

SOUZA, Mariana M. Os limites e o controle dos acordos de colaboração premiada: o rei está nu, ou, em terra de cego quem tem um olho é louco? In: MENDES, Soraia da Rosa (Org.). A delação/colaboração premiada em perspectiva. Brasília: IDP, 2016.

SUXBERGER, Antonio H. G.; MELLO, Gabriela S. J. V. A voluntariedade da colaboração premiada e sua relação com a prisão processual do colaborador. Revista Brasileira de Direito Processual Penal, v. 3, n. 1. Porto Alegre, Jan./Abr. 2017.

TOURINHO FILHO, Fernando da Costa. Comentários à lei dos Juizados Especiais Criminais. $8^{\mathrm{a}}$ ed., São Paulo: Saraiva, 2011.

Processo Penal. v. 1. 35ª ed., São Paulo: Saraiva, 2013.

VALLE, Juliano Keller do. Crítica à delação premiada: uma análise através da teoria do garantismo penal. São Paulo: Conceito Editorial, 2012.

VAN CLEAVE, Rachel. An Offer You Can't Refuse? Punishment Without Trial in Italy and the United States: The Search for Truth and an Efficient Criminal Justice System. San Francisco, Califórnia, Estados Unidos. 1997.

VASCONCELLOS, Vinicius Gomes de. CAPPARELLI, Bruna. Revista Eletrônica de Direito Processual. v. 15. Periódico semestral da pósgraduação stricto sensu em Direito processual da UERJ. 2015.

Reuters, 2018.

Colaboração Premiada no Processo Penal. São Paulo: Thomson

WORLD PRISON BRIEF. Disponível em:

https://www.prisonstudies.org/highest-to-lowest/prison-population-

total?field_region_taxonomy_tid=All. Acesso em: 30 out. 2019. 